\title{
New $\beta$-lactam derivatives modulate cell adhesion and signaling mediated by RGD-binding and leukocyte integrins.
}

Monica Baiula, ${ }^{a}$ Paola Galletti, ${ }^{b}$ Giulia Martelli, ${ }^{b}$ Roberto Soldati, ${ }^{b}$ Laura Belvisi, ${ }^{c}$ Monica Civera $^{c}$ Samantha Deianira Dattoli, ${ }^{a}$ Santi Mario Spampinato ${ }^{a *}$, and Daria Giacomini ${ }^{b *}$

${ }^{a}$ Department of Pharmacy and Biotechnology, University of Bologna, Via Irnerio, 48, 40126, Bologna, Italy

${ }^{\mathrm{b}}$ Department of Chemistry "G. Ciamician", University of Bologna, Via Selmi 2, 40126 Bologna, Italy.

${ }^{\mathbf{c}}$ Department of Chemistry, University of Milan, Via Golgi 19, 20133 Milan, Italy

KEYWORDS. Lactams, integrins, cell adhesion, azetidinones, peptidomimetics, antagonist, agonist. 
ABSTRACT. A novel series of $\beta$-lactam derivatives that was designed and synthesized to target RGD-binding and leukocyte integrins is reported. The compound library was evaluated by investigating the effects on integrin-mediated cell adhesion and cell signaling in cell lines expressing $\alpha_{V} \beta_{3}, \alpha_{v} \beta_{5}, \alpha_{v} \beta_{6}, \alpha_{5} \beta_{1}, \alpha_{I I b} \beta_{3}, \alpha_{4} \beta_{1}$, and $\alpha_{L} \beta_{2}$ integrins. SAR analysis of the new series of azetidinones enabled the recognition of structural elements associated with integrin selectivity. We obtained selective and potent agonists that could induce cell adhesion and promote cell signaling mediated by $\alpha_{\mathrm{V}} \beta_{3}, \alpha_{\mathrm{v}} \beta_{5}, \alpha_{5} \beta_{1}$, or $\alpha_{4} \beta_{1}$ integrin, and antagonists for the integrins $\alpha_{\mathrm{v}} \beta_{3}$ and $\alpha_{5} \beta_{1}$, as well as $\alpha_{4} \beta_{1}$ and $\alpha_{\mathrm{L}} \beta_{2}$ preventing the effects elicited by the respective endogenous agonists. 


\section{INTRODUCTION}

$\beta$-Lactam compounds represent an important class of four-membered cyclic amides (azetidin2-ones) thanks to their considerable and diverse biological activities. Azetidinone derivatives first attracted attention for their antibacterial properties, but over the past few decades they have gained importance as inhibitors of various enzymes. ${ }^{1-3}$ For example, new $\beta$-lactam lipopeptides

have been reported to inhibit a bacterial signal peptidase, ${ }^{4}$ advances have been reported regarding the use of $\beta$-lactams as antagonists of cholesterol absorption, ${ }^{5}$ some azetidinones have been shown to be antagonists of human fatty acid amide hydrolase (hFAAH) ${ }^{6}$ heat shock protein $90,{ }^{7}$ and histone deacetylases, ${ }^{8}$ and some of their derivatives are antithrombotic agents. ${ }^{9}$

The presence of a $\beta$-lactam ring in a series of bioactive molecules with different protein targets allows us to consider that azetidin-2-one is a privileged structure. In particular, $\beta$-lactams have two specific structural features that are of interest with regard to biological activity: i) a constrained four-membered cyclic amide which could easily undergo ring-opening reactions by nucleophilic residues in the active sites of enzymes; e.g., this mechanism has been suggested to account for antibacterial activity and the inhibition of $\beta$-lactamases and elastases; and ii) a rigid core structure that, by reducing the conformational degrees of freedom, could favor and actually enhance directional non-covalent bonding for ligand-receptor recognition. ${ }^{10}$

Among receptor ligands that are structurally based on the $\beta$-lactam core, only a few azetidinones have been shown to exhibit activity against integrins, which are a complex family of cellular receptors (Figure 1). ${ }^{11-14}$

Integrins are $\alpha / \beta$ heterodimeric transmembrane proteins that mediate cell-cell and cellextracellular matrix (ECM) interactions by binding specific ligands. In mammals, $18 \alpha$-subunits 
and $8 \beta$-subunits assemble into 24 different integrins, which may recognize collagen, laminin, or fibronectin and other ECM proteins. Eight integrins bind to ECM proteins sharing the tripeptide RGD (arginine-glycine-aspartic acid). Conversely, leukocyte integrins involved in immune functions bind proteins containing LDV (leucine-aspartic acid-valine) or related sequences such as LDT (leucine-aspartic acid-threonine) and IDS (isoleucine-aspartic acid-serine) (Figure 2).

RGD integrins can preferentially bind different ECM proteins: $\alpha_{\mathrm{v}} \beta_{3}$ integrin binds, among others, vitronectin, fibronectin and osteopontin; $\alpha_{\mathrm{v}} \beta_{5}$ binds vitronectin and fibronectin; $\alpha_{\mathrm{II}} \beta_{3}$ recognizes fibrinogen, plasminogen and von Willebrand factor; $\alpha_{5} \beta_{1}$ and $\alpha_{\mathrm{v}} \beta_{6}$ mainly recognize fibronectin. ${ }^{15}$ Integrin $\alpha_{v} \beta_{6}$ may also bind other RGD-containing peptides such as the latencyassociated peptide. ${ }^{16}$ The ligand binding specificity seems to be related to the sequences flanking RGD, the auxiliary binding motifs in the ligand, and the conformational presentation of the triad. ${ }^{17}$ Numerous $\alpha_{v} \beta_{3}$ and $\alpha_{5} \beta_{1}$ ligands have been developed; moreover, powerful ligands for specific addressing and blocking of the $\alpha_{v} \beta_{3}$ integrin subtype have been published. ${ }^{18-19}$ As regards $\alpha_{\mathrm{v}} \beta_{5}$ and $\alpha_{\mathrm{v}} \beta_{6}$ integrins, novel ligands have been recently proposed. ${ }^{20-21}$

The ability of integrins to bind and associate with various components of the ECM or soluble ligands largely depends on the structural conformations of the two $\alpha$ and $\beta$ subunits, and distinct conformations are crucial for regulating both inside-out and outside-in cell signaling. ${ }^{22,23}$ Integrins regulate crucial aspects of cellular functions, including migration, adhesion, differentiation, growth and survival, by communicating bidirectional signals between the extracellular and intracellular environments. ${ }^{24}$ 
<smiles>CCCC(NC(=O)CN1C[C@](Cc2ccccc2)(NC(=O)[C@H](CC(=O)O)NC(=O)CNC(=O)[O-])C1=O)C(=O)NCCNC(=N)N</smiles><smiles>[B]CCC[C@H]1NC(=O)CN2C[C@](Cc3ccccc3)(NC1=O)C(=O)N[C@@H](CC(=O)O)C(=O)N2CC(=O)O</smiles><smiles>[NH3+]Cc1ccc(NC(=O)N2C(=O)CC2CC(=O)O)cc1</smiles><smiles>NCc1ccc(NC(=O)N2C(=O)CC2C(=O)O)cc1</smiles>

Figure 1. Previously reported $\beta$-lactams as integrin ligands.

The crystallization of a soluble integrin heterodimer revealed that integrins exist in an inactive state with their ligand-binding domains facing the cell membrane. ${ }^{25}$ Activation occurs when membrane-bound proteins increase the affinity of ectodomains for extracellular ligands that promote cell adhesion and modulate intracellular signaling cascades. ${ }^{26}$ The ligand-binding site forms a region at the intersection of the $\alpha$ and $\beta$ subunits; as regards RGD integrins, both the $\alpha$ chain $^{27}$ and $\beta$ subunit may participate. ${ }^{28}$

The binding of endogenous ligands to integrins recruits several cellular components and modulates intracellular signaling cascades, especially those leading to the activation of focal adhesion kinase (FAK) and mitogen-activated protein kinase (MAPK) pathways that play a crucial role in the regulation of numerous cell functions. ${ }^{29}$ The tight regulation of integrin signaling is paramount for normal physiological functions such as migration, proliferation and 
differentiation, and misregulated integrin activity is associated with several pathological conditions. Therefore, extensive effort has been made to discover and develop integrin antagonists for use in clinical applications. ${ }^{27,} 30$ To date, most efforts have focused on the development of small molecules or antibodies that can inhibit mainly the following integrins: $\alpha_{v} \beta_{3 / 5}$ and $\alpha_{5} \beta_{1}$, which have been implicated in tumor development; $\alpha_{4} \beta_{1 / 7}$ and $\alpha_{L} \beta_{2}$, which have been implicated in the regulation of immune functions, and $\alpha_{\text {IIb }} \beta_{3}(\mathrm{GpIIbIIIa)}$, which has been implicated in platelet aggregation. ${ }^{15}$ Interestingly, several studies have suggested that small molecules that act as integrin agonists may have therapeutic efficacy. These include an agonist of $\alpha_{\mathrm{M}} \beta_{2}$ integrin $^{31}$ that ameliorates kidney transplantation, ${ }^{32}$ an agonist of $\alpha_{\mathrm{L}} \beta_{2}$ integrin that inhibits lymphocyte trans-endothelial migration, ${ }^{33}$ and an agonist of $\alpha_{4} \beta_{1}$ integrin that induces progenitor cell adhesion. ${ }^{34}$ In agreement with these studies, Du et al. reported that small RGD peptides that bind to $\alpha_{\mathrm{IIb}} \beta_{3}$ integrin behaved as partial agonists or competitive antagonists of cell adhesion. ${ }^{35}$ These latter studies suggest that, through modification of the sequence of small peptides or with the use of small molecules, an integrin antagonist could be converted to an agonist that could increase cell adhesion and modulate intracellular signaling pathways.

With regard to $\beta$-lactams as integrin ligands, Palomo et al. and Aizpurua et al. embedded an azetidinone scaffold in cyclic peptides or pseudopeptides that contain the RGD recognition motif or a RGD-like sequence (Figure 1, $\mathbf{A}$ and $\mathbf{B}) .{ }^{11-13}$ The incorporation of conformational constraints, such as the $\beta$-lactam scaffold inserted in a cyclic peptide in this case, was, in general, intended to enhance selectivity and modulate the affinity toward the receptor. 


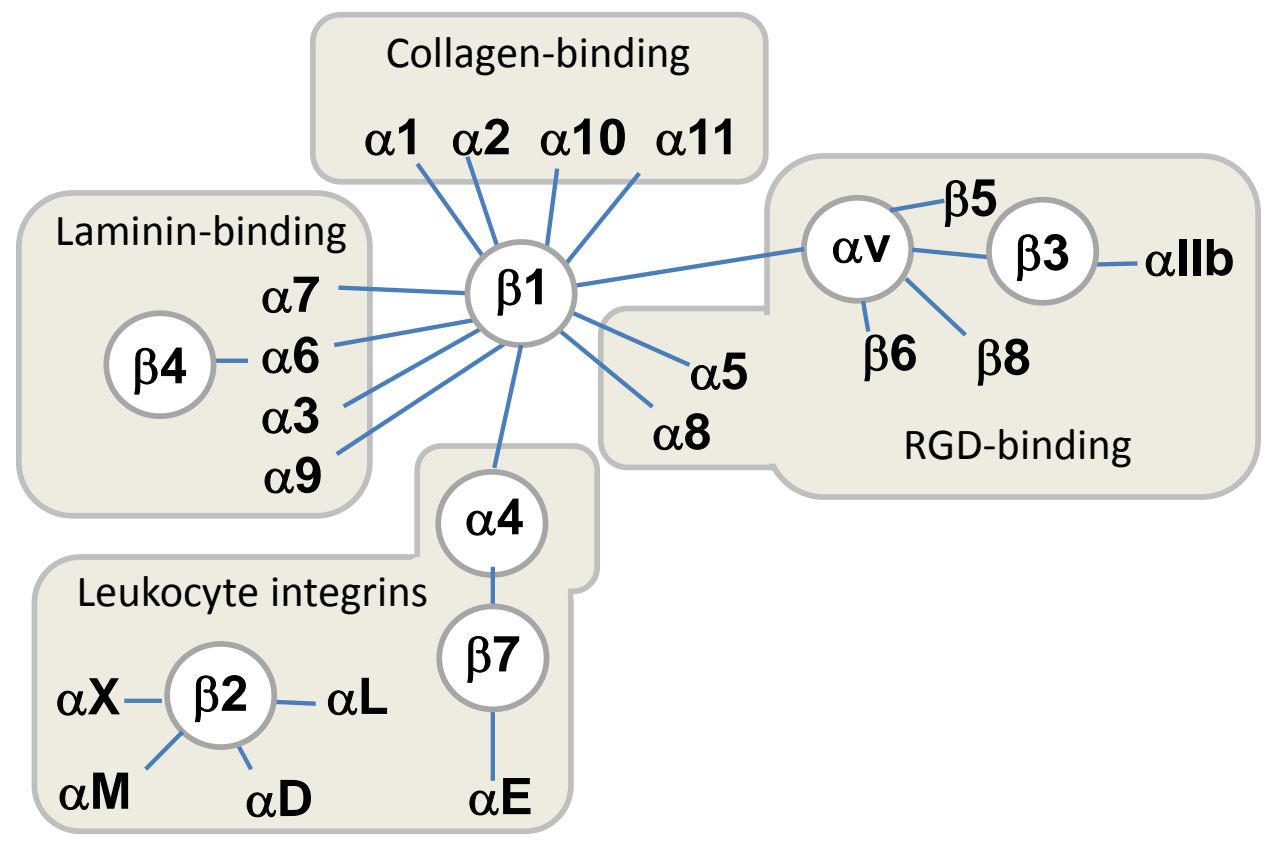

Figure 2. Classification of heterodimeric integrins according to specific combinations of the $\alpha$ and $\beta$ chains.

Recently, we reported a preliminary study on the design and synthesis of three new azetidinones as potential integrin ligands $\mathbf{1 - 3}$ (Figure 1). ${ }^{14}$ The approach used for the design of the new molecules was based on rationalization from known integrin ligands. We set out to explore molecules that contained azetidinone as a rigid cyclic central core, with two arms holding the carboxylic acid and a basic moiety, as in the RGD sequence, with a spacing of 9 to 14 atoms. The 4-amidobenzylamine residue was chosen as a basic terminus that was directly linked to the $\beta$-lactam nitrogen atom as in urea derivatives, and a carboxylic acid was located on the $\mathrm{C}-4$ side chain. When these new molecules were tested on cell lines K562 (human erythroleukemia expressing $\alpha_{5} \beta_{1}$ integrin) and SK-MEL-24 (human malignant melanoma expressing $\alpha_{\mathrm{v}} \beta_{3}$ integrin), we observed the concentration-dependent enhancement of fibronectin-mediated 
adhesion. In particular, $\beta$-lactam 1 has a higher affinity toward $\alpha_{5} \beta_{1}$ integrin $\left(\mathrm{EC}_{50} 12 \mathrm{nM}\right)$ and $\beta$-lactam 2 is more selective for integrin $\alpha_{\mathrm{v}} \beta_{3}\left(\mathrm{EC}_{50} 11 \mathrm{nM}\right){ }^{14}$

Herein we describe the synthesis of a small library of new $\beta$-lactam derivatives (Chart 1) that were specifically designed by a structure-based strategy to target particular classes of integrins. The biological activities of these new compounds were evaluated by investigating their effects on integrin-mediated cell adhesion in suitable cell lines expressing the RGD integrins $\alpha_{\mathrm{v}} \beta_{3}, \alpha_{\mathrm{v}} \beta_{5}$, $\alpha_{v} \beta_{6}, \alpha_{5} \beta_{1}$ and $\alpha_{I I b} \beta_{3}$, and leukocyte integrins $\alpha_{4} \beta_{1}$ and $\alpha_{L} \beta_{2}$; furthermore, their effects on cell signaling activated by integrins $\alpha_{\mathrm{v}} \beta_{3}, \alpha_{5} \beta_{1}, \alpha_{\mathrm{II}} \beta_{3}, \alpha_{4} \beta_{1}$ and $\alpha_{\mathrm{L}} \beta_{2}$ were investigated. A structureactivity analysis of this new series of azetidinones allowed us to identify structural elements associated with integrin selectivity and, by adopting this approach, we obtained selective and potent agonists that could induce cell adhesion mediated by $\alpha_{v} \beta_{3}, \alpha_{v} \beta_{5}, \alpha_{5} \beta_{1}$, or $\alpha_{4} \beta_{1}$ integrin, and antagonists for $\alpha_{\mathrm{v}} \beta_{3}, \alpha_{\mathrm{v}} \beta_{6}$ and $\alpha_{5} \beta_{1}$, as well as $\alpha_{4} \beta_{1}$ and $\alpha_{\mathrm{L}} \beta_{2}$. 

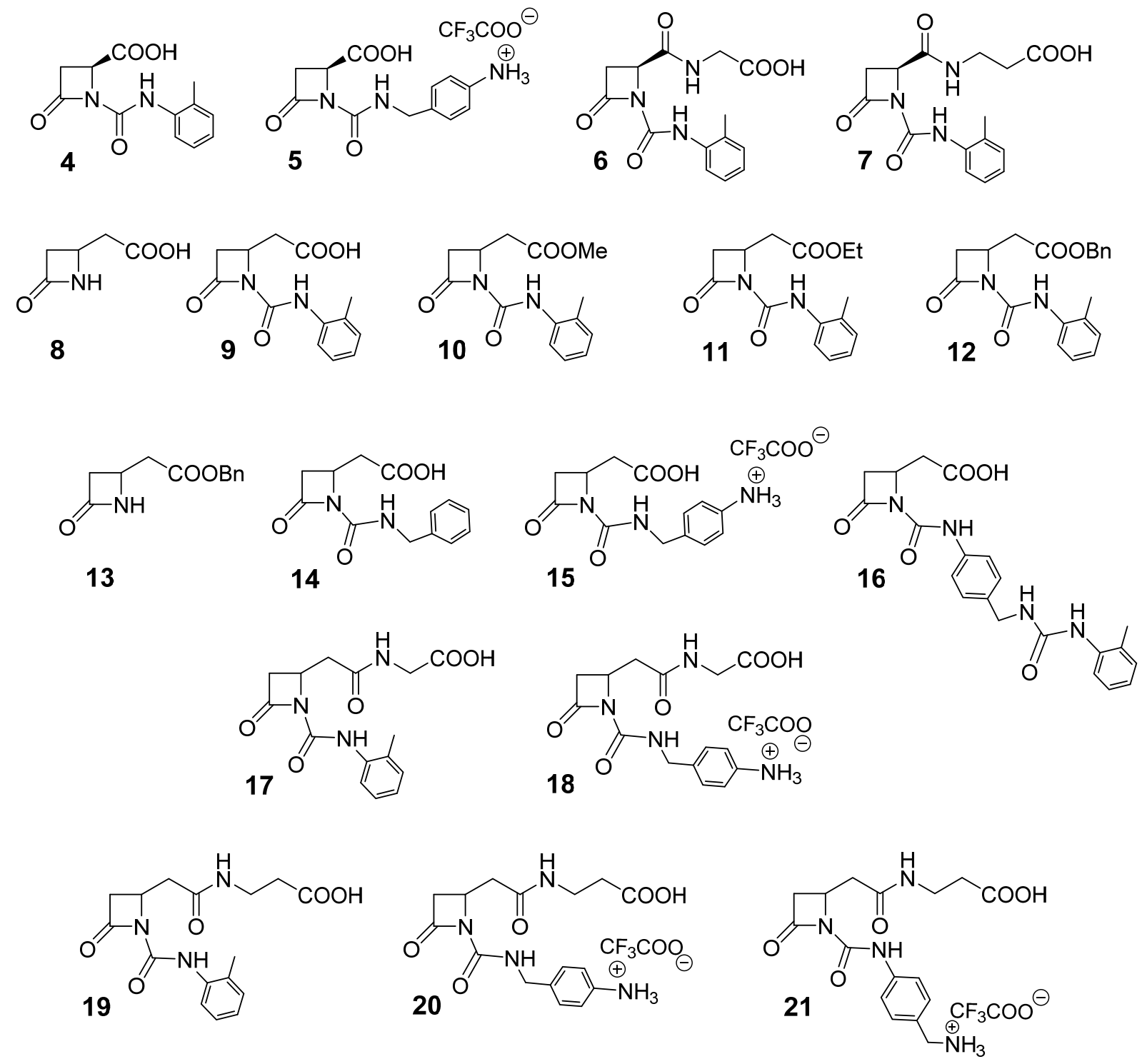

Chart 1. $\beta$-Lactam compounds evaluated in this study. 


\section{RESULTS AND DISCUSSION}

\section{Synthesis.}

We were intrigued by the possibility of using only a $\beta$-lactam core to obtain a constrained molecule that could favor complexation with the receptor, excluding the insertion of an azetidinone ring in cyclic peptides (Figure 1). The $\beta$-lactam ring represents a site of conformational restriction with a cyclic $\beta$-amino acid residue ${ }^{36}$ which could give a favorable alignment of both the amine and carboxylate moieties on the ligand, which would satisfy the crucial requirements for integrin affinity and selectivity. ${ }^{37}$

Of the various integrin ligands explored by others, we were particularly interested in the antagonists reported by Tolomelli et al. ${ }^{38-41}$ They found that a 4-aminobenzyl-amide residue was an effective Arg mimetic with an increased affinity for $\alpha_{v} \beta_{3}$ and $\alpha_{5} \beta_{1}$ integrins, whereas the presence of a 4([(N-2-methylphenyl)ureido]-phenylacetyl motif (PUPA) greatly enhanced bioactivity and specificity for $\alpha_{4} \beta_{1}$ integrins. $^{42}$

We chose to install a 4-aminobenzyl-amido- or its isomeric 4-aminomethyl-phenyl-amidoresidue on the $\mathrm{N}-1$ nitrogen atom of the azetidinone via a condensation reaction with isocyanates (Figure 3). These two isomeric substitutions were selected to evaluate the influence of the basicity of the amine terminus; in this case we compared benzylamine and aniline residues. ${ }^{43}$

The carboxylic acid function which could coordinate at the metal ion-dependent adhesion site (MIDAS) of the $\beta$-subunit of integrins ${ }^{37}$ was placed on the $\mathrm{C}-4$ side chain of the azetidinone. In detail, $\beta$-lactams 4-7 (Chart 1) have a C-4 carboxylic acid residue, as either a free acid or dipeptide, and compounds 8-21 have a C-4 acetic acid residue, as either a free acid, ester or 
dipeptide. In dipeptide derivatives, two amino acids were coupled with the azetidinone carboxylic acid, and glycine or $\beta$-alanine was chosen to have un-substituted flexible chains. For compounds 1-3, a panel of 18 new azetidinones was synthesized starting from two commercially available compounds, L-aspartic acid and 4-acetoxy-azetidinone. The general synthetic approach is depicted in Figure 3. Compounds 4-7 were prepared starting from L-aspartic acid, cyclization to give azetidin-2-one 3-carboxyester, insertion of the imide by condensation with an isocyanate, and $\mathrm{C}-4$ side chain elongation via a peptide-coupling procedure. The $\mathrm{C}-4$ acetic acid derivatives 8-21 were synthesized from the commercially available 4-acetoxy-azetidinone with a Reformatsky reagent by benzyl bromoacetate. ${ }^{44-46}$ Again, the imido group was obtained with the appropriate isocyanate and peptide coupling gave higher molecular weight derivatives.
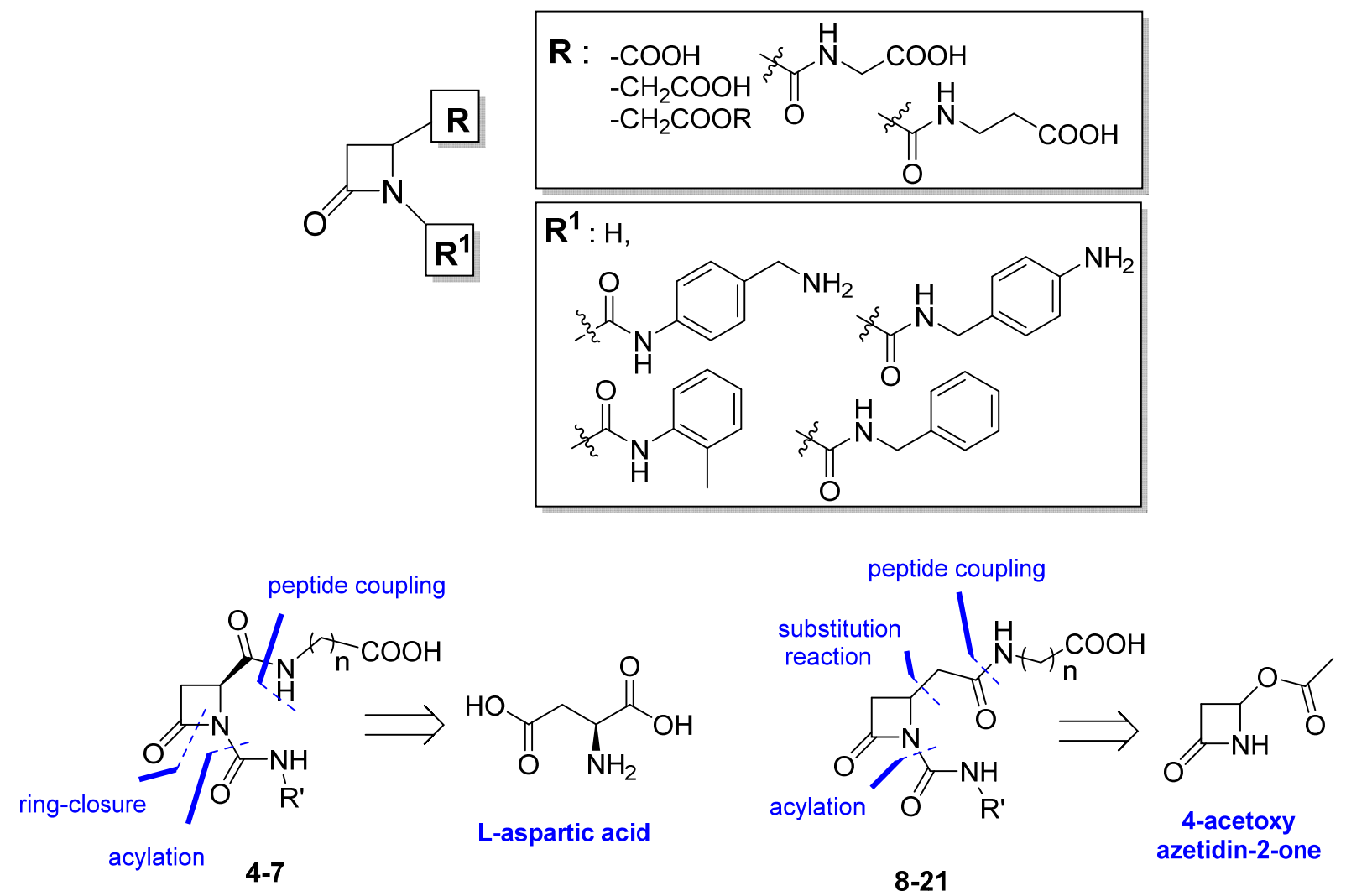

Figure 3. Substituent variations and synthetic strategies for $\beta$-lactams 4-21. 
A careful strategy for protecting the carboxylic acid and the amine terminus was developed to preserve the $\beta$-lactam ring throughout the synthesis, and in particular in the final deprotection step. Particular attention was paid to specific combinations of temporary or permanent protecting groups to achieve full or partial deprotection depending on the requirements of the synthetic strategy. The synthesis of compounds 4-21 is described in detail in Schemes 1-4.

The 4-carboxylic-azetidin-2-one benzyl ester 22 was obtained in a two-step procedure starting from L-aspartic acid as previously reported ${ }^{14}$ (Scheme 1). Treatment of 22 with NaHMDSA in THF at $-78^{\circ} \mathrm{C}$ and tert-butyl(4-(isocyanatomethyl)phenyl)carbamate 23 , freshly prepared with triphosgene (see the Experimental Section), gave 24. Hydrogenolysis gave the corresponding acid 25 and final treatment with trifluoroacetic acid (TFA) furnished compound $\mathbf{5}$ as a trifluoroacetate salt.

Scheme 1. Synthesis of $\beta$-lactams 4-7

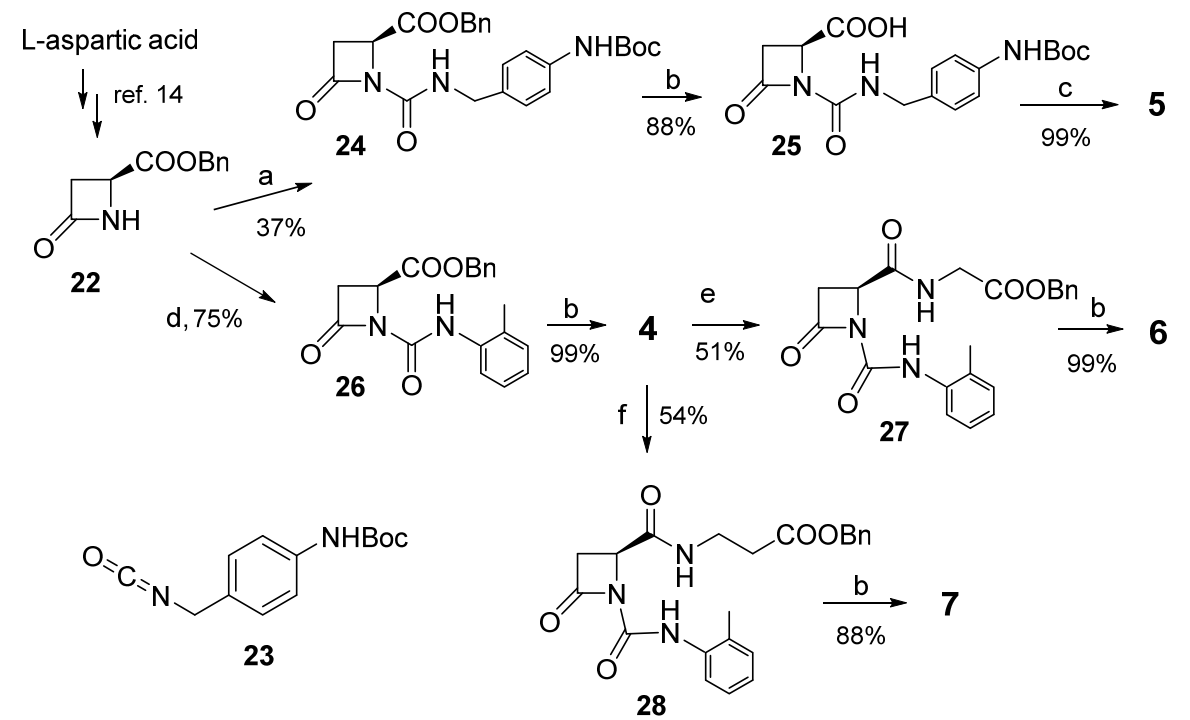


${ }^{\mathrm{a}}$ Reagents and conditions: (a) NaHMDSA, tert-butyl(4-(isocyanatomethyl)phenyl)carbamate 23, $\mathrm{THF},-78^{\circ} \mathrm{C}, 1 \mathrm{~h}$; (b) $\mathrm{H}_{2}, \mathrm{Pd} / \mathrm{C} 10 \%, \mathrm{THF} / \mathrm{MeOH}=1: 1, \mathrm{rt}, 2 \mathrm{~h}$; (c) TFA, $\mathrm{CH}_{2} \mathrm{Cl}_{2}, 0^{\circ} \mathrm{C}$ then $\mathrm{rt} 24 \mathrm{~h}$; (d) $\mathrm{K}_{2} \mathrm{CO}_{3}, o$-tolyl isocyanate, $\mathrm{CH}_{3} \mathrm{CN}, 2 \mathrm{~h}$, rt; (e) oxalylchloride, TEA, $\mathrm{CH}_{2} \mathrm{Cl}_{2}$, glycine benzylester $\cdot \mathrm{HCl}$, DMAP, rt, 16h; (f) oxalylchloride, TEA, $\mathrm{CH}_{2} \mathrm{Cl}_{2}, \beta$-alanine benzylester·PTSA, DMAP, rt, $16 \mathrm{~h}$.

Compound 26 was obtained from 22 with the commercially available $o$-tolyl isocyanate in acetonitrile and potassium carbonate. Subsequent hydrogenolysis gave $\mathbf{4}$ in good yields. The carboxylic acid 4 was coupled with glycine benzylester or $\beta$-alanine benzylester to give compounds $\mathbf{2 7}$ and 28, respectively. Finally, azetidinones $\mathbf{6}$ and $\mathbf{7}$ were obtained from $\mathbf{2 7}$ and $\mathbf{2 8}$ by hydrogenolysis.

The syntheses of $\beta$-lactams 8-21 include a common origin: a substitution reaction on the 4acetoxy azetidinone by a Reformatsky reagent as outlined in Scheme 2. Methyl-, ethyl-, or benzyl-bromoacetates were treated with an excess of metallic $\mathrm{Zn}$ in THF to furnish the corresponding Reformatsky reagents which were then coupled with 4-acetoxyazetidin-2-one to give 4-acetate-azetidin-2-one esters 29, 30, and $\mathbf{1 3}$ in good overall yields after flash chromatography $^{14}$ (Scheme 2). Treatment of the three esters with $o$-tolyl isocyanate under basic conditions provided the imido-azetidinones 10, 11, and 12. Azetidinones 8 and 9 were then obtained by hydrogenolysis from $\mathbf{1 3}$ and $\mathbf{1 2}$, respectively. The azetidinone $\mathbf{9}$ was subjected to peptide coupling with glycine benzylester or $\beta$-alanine benzylester with EDC as a coupling reagent, TEA, and a catalytic amount of dimethylaminopyridine (DMAP) to give the intermediates $\mathbf{3 8}$ and 39, which were deprotected by hydrogenolysis to give $\mathbf{1 7}$ and $\mathbf{1 9}$, respectively (Scheme 2). The N-1-side chain was inserted on azetidinone 13, which had been 
previously deprotonated at $-78^{\circ} \mathrm{C}$ with sodium hexamethyl disilylamide (NaHMDSA), with tertbutyl(4-(isocyanatomethyl)phenyl) carbamate 23 (Scheme 3), which had been obtained in turn from 4- $N$-Boc-aminobenzylamine with triphosgene (see the Experimental Section for details).

Scheme 2. Synthesis of $\beta$-lactams 8-13, 17, and $\mathbf{1 9}^{\text {a }}$

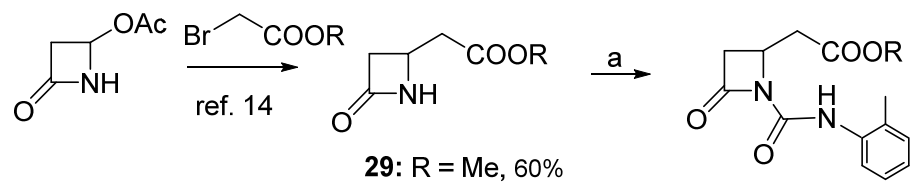

$$
8 \begin{array}{rl}
b \quad 30: R=E t, 64 \% & 10: R=M e, 74 \% \\
\text { 13: } R=B n, 65 \% & 11: R=E t, 81 \% \\
99 \% & \text { 12: } R=B n, 78 \%
\end{array}
$$

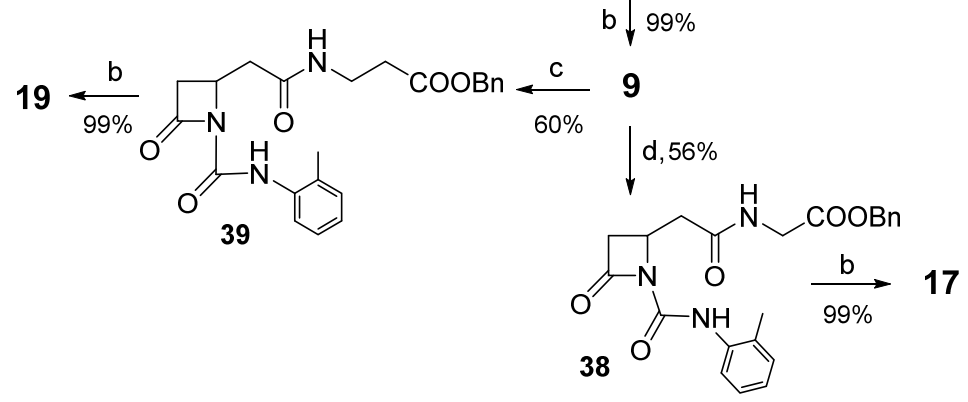

${ }^{\text {a }}$ Reagents and conditions: (a) $\mathrm{K}_{2} \mathrm{CO}_{3}, o$-tolyl isocyanate, $\mathrm{CH}_{3} \mathrm{CN}, 2 \mathrm{~h}, \mathrm{rt}$; (b) $\mathrm{H}_{2}, \mathrm{THF} / \mathrm{MeOH}(1: 1), \mathrm{Pd} / \mathrm{C} 10 \%, 2 \mathrm{~h}$, rt; (c) EDC, TEA, DMAP, $\beta$-alanine benzylester PTSA, $\mathrm{CH}_{2} \mathrm{Cl}_{2}, 0^{\circ} \mathrm{C}$ to rt, $16 \mathrm{~h}$; (d) EDC, TEA, DMAP, glycine benzylester.PTSA, $\mathrm{CH}_{2} \mathrm{Cl}_{2}, 0^{\circ} \mathrm{C}$ to rt. $16 \mathrm{~h}$.

Hydrogenolysis of the resulting adduct 31 gave 32, which in turn provided compound 15 by treatment with trifluoroacetic acid. Azetidinone $\mathbf{3 6}$ was obtained by a similar procedure in two steps starting from 13 and tert-butyl 4-isocyanatobenzylcarbamate 34 (see the Experimental Section). Treatment of $\mathbf{3 6}$ with commercially available $o$-tolyl isocyanate and trimethylamine 
gave 37, which in turn gave azetidinone 16 by hydrogenolysis. Compound 14 was obtained in two steps from 13 by condensation with commercially available benzyl isocyanate and hydrogenolysis. Azetidinones $\mathbf{1 8}$ and $\mathbf{2 0}$ were obtained from carboxylic acid $\mathbf{3 2}$ by peptide coupling with glycine benzyl ester or $\beta$-alanine benzyl ester, respectively (Scheme 4).

Scheme 3. Synthesis of $\beta$-lactams 14-16

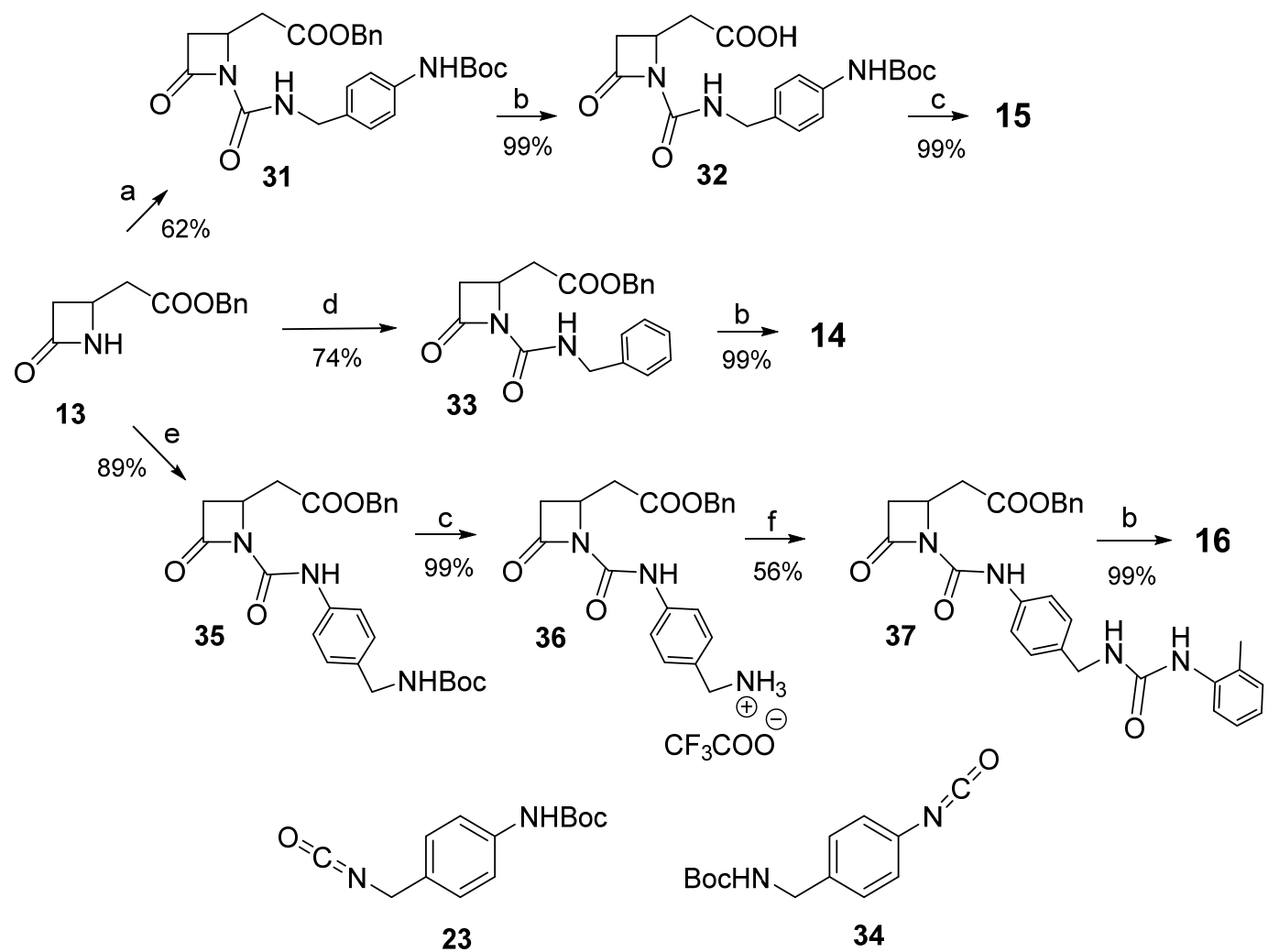

${ }^{\mathrm{a}}$ Reagents and conditions: (a) NaHMDSA, tert-butyl(4-(isocyanatomethyl)phenyl)carbamate $23, \mathrm{THF},-78^{\circ} \mathrm{C}, 1 \mathrm{~h}$; (b) $\mathrm{H}_{2}, \mathrm{Pd} / \mathrm{C} 10 \%, \mathrm{THF} / \mathrm{MeOH}=1: 1, \mathrm{rt}, 2 \mathrm{~h}$; (c) TFA, $\mathrm{CH}_{2} \mathrm{Cl}_{2}, 0^{\circ} \mathrm{C}$ then $\mathrm{rt}, 24 \mathrm{~h}$; (d) $\mathrm{K}_{2} \mathrm{CO}_{3}$, benzyl isocyanate, $\mathrm{CH}_{3} \mathrm{CN}, 2 \mathrm{~h}$, rt; (e) NaHMDSA, tert-butyl 4-isocyanatobenzylcarbamate 34, THF, -78 ${ }^{\circ} \mathrm{C}, 1 \mathrm{~h}$; (f) TEA, $o$-tolyl isocyanate, $0^{\circ} \mathrm{C}$ then $\mathrm{rt}, 2 \mathrm{~h}$. 
When intermediates 40 and $\mathbf{4 2}$ were subjected to a two-step procedure consisting of hydrogenolysis and treatment with TFA for the final deprotection, compounds $\mathbf{1 8}$ and $\mathbf{2 0}$ were obtained in very good yields. Preliminary hydrogenolysis of compound $\mathbf{3 5}$ gave the intermediate 44, which, via peptide coupling with $\beta$-alanine benzylester, hydrogenolysis and treatment with TFA, gave the final compound 21 (Scheme 4).

Scheme 4. Synthesis of $\beta$-lactams 18, 20, and 21. ${ }^{\mathrm{a}}$

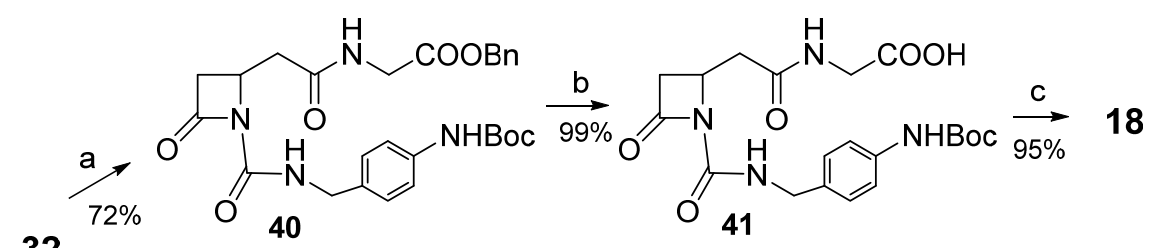

32

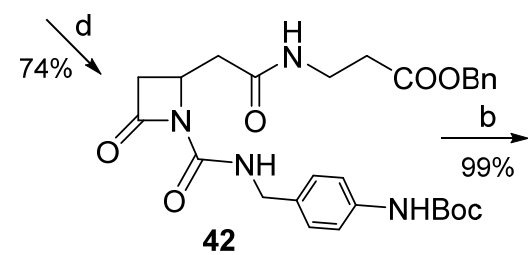<smiles>CC(C)(C)Nc1ccc(CNC(=O)N2C(=O)CC2CC(=O)NCCC(=O)O)cc1</smiles>
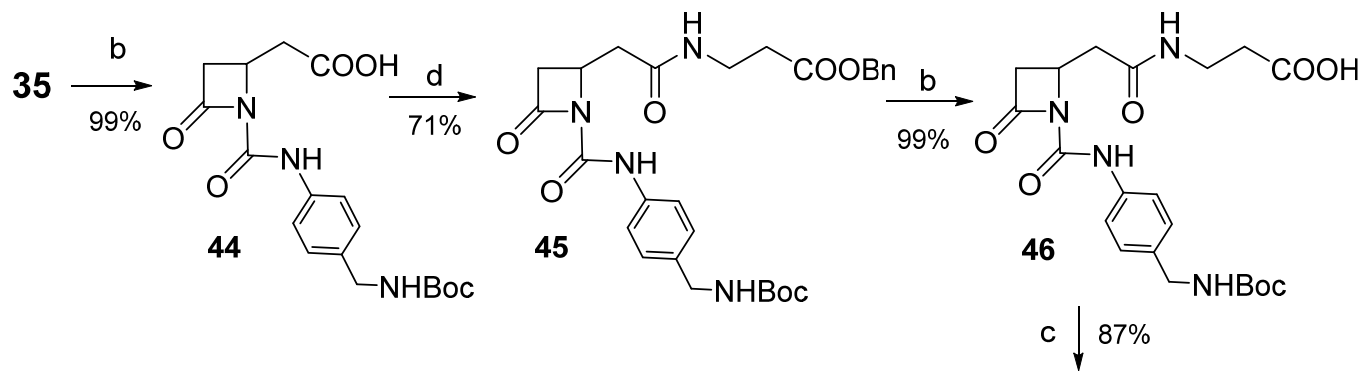

21

\footnotetext{
${ }^{a}$ Reagents and conditions: (a) DCC, TEA, DMAP, $\mathrm{CH}_{2} \mathrm{Cl}_{2}$, glycine benzylester.PTSA, $0^{\circ} \mathrm{C}$ to rt, $16 \mathrm{~h}$; (b) $\mathrm{H}_{2}, \mathrm{Pd} / \mathrm{C}$ $10 \%, \mathrm{THF} / \mathrm{MeOH}=1: 1, \mathrm{rt}, 2 \mathrm{~h}$; (c) TFA, $\mathrm{CH}_{2} \mathrm{Cl}_{2}, 0^{\circ} \mathrm{C}$ then $\mathrm{rt}, 24 \mathrm{~h}$; (d) DCC, TEA, DMAP, $\beta$-alanine benzylester-PTSA, $\mathrm{CH}_{2} \mathrm{Cl}_{2}, 0^{\circ} \mathrm{C}$ to rt, $16 \mathrm{~h}$.
} 


\section{Cell adhesion and solid-phase binding assays}

To investigate the activity and selectivity profiles of $\beta$-lactam derivatives, we performed adhesion assays with different cell lines expressing the RGD integrins $\alpha_{\mathrm{v}} \beta_{3}, \alpha_{\mathrm{v}} \beta_{5}, \alpha_{\mathrm{v}} \beta_{6}, \alpha_{5} \beta_{1}$ and $\alpha_{\text {IIb }} \beta_{3}$ or leukocyte integrins $\alpha_{4} \beta_{1}$ and $\alpha_{L} \beta_{2}$. In these assays, cells were seeded onto plates coated with specific substrates and allowed to adhere before the number of adherent cells was determined in the presence of increasing concentrations of the test compounds $\left(1 \times 10^{-10} \mathrm{M}\right.$ $\left.1 \times 10^{-4} \mathrm{M}\right)$. The peptides H-Gly-Arg-Gly-Asp-Thr-Pro-OH (47), Ac-Asp-Arg-Leu-Asp-Ser-OH (48) ${ }^{38}$ cyclo(-Arg-Gly-Asp-D-Phe-Val) (49) ${ }^{47-48}$ ( $N$-[[4-[[[(2-methylphenyl)amino]carbonyl $]$ amino]-phenyl]acetyl]-l-leucyl-1-aspartyl-l-valyl-1-proline (50) (BIO-1211) ${ }^{49}$ and Tirofiban $(\mathbf{5 1})^{50}$ were included as reference ligands for the various integrins assayed. Novel ligands that inhibited cell adhesion promoted by fibronectin, fibrinogen, VCAM-1 or ICAM-1 were referred to as antagonists, whereas compounds that increased fibronectin- or fibrinogen- or VCAM-1- or ICAM-1-mediated cell adhesion were considered to be agonists. All of the $\beta$-lactam derivatives that were effective in cell-adhesion tests are summarized in Table 1, whereas compounds $\mathbf{6}, \mathbf{1 0}$, $11,12,13,16$, and 18 were completely inactive and their data are not shown. Integrin selectivity of each compound for one or more integrins over others assayed is also shown in Table 1.

Any potential cell toxicity of $\beta$-lactams under investigations was evaluated by Annexin V-7AAD assay by flow cytometry. We observed that all compounds $\left(10^{-4} \mathrm{M}\right)$ added for three hours to the cell lines used in this study did not cause any cell necrosis and/or apoptosis (data not shown).

The preliminary results showed an unexpected activity of azetidinones $\mathbf{1}$ and $\mathbf{2}$ as promoters of cell adhesion mediated by $\alpha_{5} \beta_{1}$ and $\alpha_{\mathrm{v}} \beta_{3}$ integrins, ${ }^{14}$ with an interesting potency at the 
nanomolar level (Table 1). Compound 1 was not able to discriminate between $\alpha_{v} \beta_{3}$ and $\alpha_{5} \beta_{1}$ integrins whereas 2 preferentially activated $\alpha_{v} \beta_{3}$ integrin. 
Table 1. Effects of active $\beta$-lactam compounds on RGD-binding and leukocyte integrin-mediated cell adhesion. Data are presented as $\mathrm{EC}_{50}$ for agonists (in bold), and as $\mathrm{IC}_{50}$ for antagonists $(\mathrm{nM})$. The ability of $\beta$-lactams to increase or inhibit cell adhesion mediated by a specific integrin ligand (fibronectin for $\alpha_{5} \beta_{1}, \alpha_{\mathrm{v}} \beta_{3}$ and $\alpha_{\mathrm{v}} \beta_{6}$, fibrinogen for $\alpha_{\mathrm{v}} \beta_{5}$ and $\alpha_{\mathrm{IIb}} \beta_{3}$, VCAM-1 for $\alpha_{4} \beta_{1}$, and ICAM-1 for $\alpha_{\mathrm{L}} \beta_{2}$ ) was evaluated.

\begin{tabular}{|c|c|c|c|c|c|c|c|c|c|}
\hline \multirow[b]{2}{*}{$\begin{array}{c}\text { comp. } \\
\text { number }\end{array}$} & \multirow[b]{2}{*}{ structure } & \multicolumn{5}{|c|}{ RGD-binding integrins } & \multicolumn{2}{|c|}{ Leukocyte integrins } & \multirow{2}{*}{$\begin{array}{l}\text { Preferential } \\
\text { selectivity }^{\mathrm{h}}\end{array}$} \\
\hline & & $\alpha_{v} \beta_{3}$ & $\alpha_{v} \beta_{5}$ & $\alpha_{v} \beta_{6}$ & $\alpha_{5} \beta_{1}$ & $\alpha_{\mathrm{IIb}} \boldsymbol{\beta}_{3}$ & $\boldsymbol{\alpha}_{4} \boldsymbol{\beta}_{1}$ & $\alpha_{L} \beta_{2}$ & \\
\hline 1 & & $\begin{array}{c}55.00 \pm 0.04^{b} \\
\text { agonist }\end{array}$ & $\begin{array}{c}5.09 \pm 0.07 \\
\text { agonist }\end{array}$ & $\begin{array}{l}167 \pm 6 \\
\text { agonist }\end{array}$ & $\begin{array}{c}12.00 \pm 0.02^{\mathrm{b}} \\
\text { agonist }\end{array}$ & $>5000$ & $>5000$ & $\begin{array}{l}2410 \pm 64 \\
\text { antagonist }\end{array}$ & $\alpha_{v} \beta_{5}$ and $\alpha_{5} \beta_{1}$ \\
\hline 2 & & $\begin{array}{l}11.00 \pm 0.03 \\
\text { agonist }\end{array}$ & $\begin{array}{c}505 \pm 17 \\
\text { agonist }\end{array}$ & $>5000$ & $\begin{array}{c}763.00 \pm 0.08^{b} \\
\text { agonist }\end{array}$ & $>5000$ & $>5000$ & $>5000$ & $\alpha_{v} \beta_{3}$ \\
\hline 3 & & $>5000^{\mathrm{b}}$ & $>5000$ & $>5000$ & $\begin{array}{c}365.00 \pm 0.05^{b} \\
\text { agonist }\end{array}$ & $>5000$ & $>5000$ & $>5000$ & $\alpha_{5} \beta_{1}$ \\
\hline
\end{tabular}


5

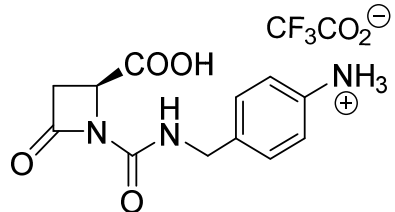

15

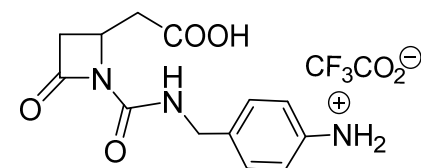

20

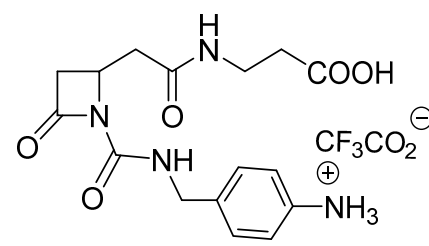

21
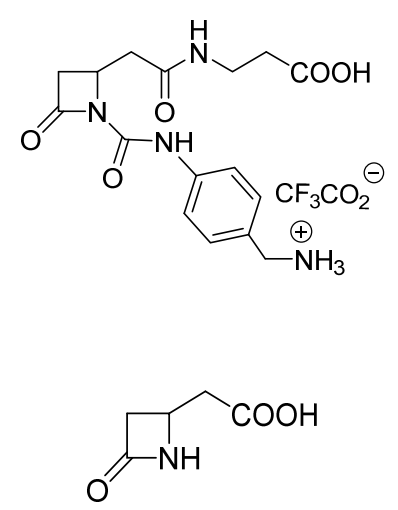

14

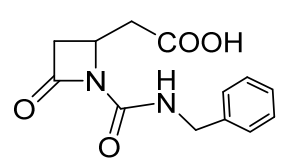

$$
>5000
$$

$$
>5000
$$

$$
>5000
$$

$$
\begin{gathered}
525.0 \pm 1.2 \\
\text { antagonist }
\end{gathered}
$$$$
>5000
$$
agonist

$>5000$

$574.0 \pm 1.7$ antagonist

$0.39 \pm 0.02$ antagonist

$>5000$

$>5000$

$>5000$

$1050 \pm 17$
antagonist

$>5000$

$>5000$

$>5000$ antagonist

$>5000$

$>5000$

$>5000$

$6.7 \pm 0.6$

agonist

$1563 \pm 69$

$>5000$

$>5000$

$\alpha_{5} \beta_{1}$

$40.9 \pm 0.8$

antagonist

$376 \pm 15$

agonist

$>5000$

$1031 \pm 35$

agonist

$311 \pm 35$

agonist

$>5000$

$1627 \pm 23$

antagonist

$\alpha_{\mathrm{v}} \beta_{3}$

$>5000$

$>5000$

$>5000$

$417 \pm 6$

antagonist
$>5000$

$>5000$

$>5000$ $\alpha_{5} \beta$

\section{$\beta_{5}$}

$\alpha_{\mathrm{L}} \beta_{2}$ and $\alpha_{\mathrm{v}} \beta_{3}$ 
4

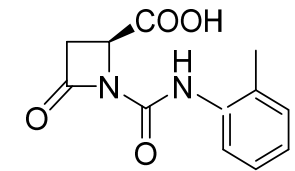

7

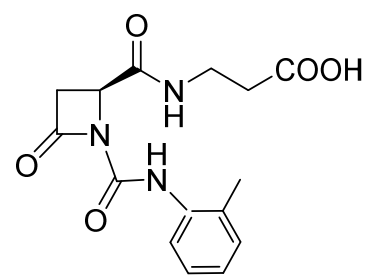

9

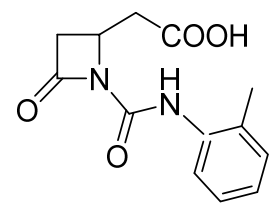

17

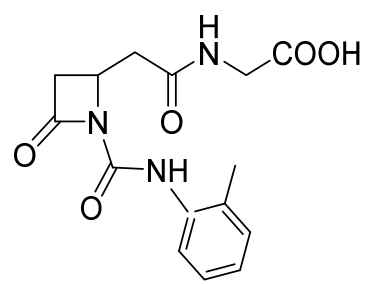

$>5000$

$>5000$

$>5000$

$9.9 \pm 0.1$

agonist

$187 \pm 3$
agonist

$670 \pm 24$

agonist

$44.4 \pm 0.8$
antagonist

$49.0 \pm 2.9$

agonist

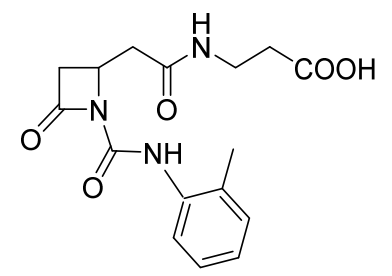

$>5000$

$17.4 \pm 0.8$

antagonist

$>5000$

$>5000$ agonist 


\begin{tabular}{|c|c|c|c|c|c|c|c|c|}
\hline 47 & $\begin{array}{c}\text { H-Gly-Arg-Gly-Asp-Thr-Pro- } \\
\text { OH }\end{array}$ & $\begin{array}{c}925.5 \pm 6.3 \\
\text { antagonist }\end{array}$ & $\begin{array}{l}34.2 \pm 0.7 \\
\text { antagonist }\end{array}$ & $>5000$ & $\begin{array}{c}0.62 \pm 0.09 \\
\text { antagonist }\end{array}$ & $>5000$ & $\mathrm{nd}^{\mathrm{d}}$ & nd \\
\hline 48 & Ac-Asp-Arg-Leu-Asp-Ser-OH ${ }^{\mathrm{e}}$ & $\begin{array}{c}25 \pm 3 \\
\text { antagonist }\end{array}$ & $\begin{array}{c}2278 \pm 0.07 \\
\text { antagonist }\end{array}$ & $>5000$ & $>5000$ & $>5000$ & nd & nd \\
\hline 50 & BIO- $1211^{\mathrm{f}}$ & nd & nd & nd & nd & nd & $\begin{array}{c}8.6 \pm 1.5 \\
\text { antagonist }\end{array}$ & $\begin{array}{r}0.84 \pm 0.19 \\
\text { antagonist }\end{array}$ \\
\hline 49 & $\begin{array}{c}\text { Cyclo(-Arg-Gly-Asp-D-Phe- } \\
\left.\text { (Val) })^{\mathrm{g}}\right)\end{array}$ & $\begin{array}{c}146 \pm 43 \\
\text { antagonist }\end{array}$ & $\begin{array}{l}16.0 \pm 1.3 \\
\text { antagonist }\end{array}$ & $\begin{array}{l}3696 \pm 38 \\
\text { antagonist }\end{array}$ & nd & nd & nd & nd \\
\hline 51 & Tirofiban & nd & nd & nd & nd & $\begin{array}{c}9.4 \pm 0.8 \\
\text { antagonist }\end{array}$ & nd & nd \\
\hline
\end{tabular}

a) Values represent the mean $\pm \mathrm{SD}$ of three independent experiments carried out in quadruplicate.

b) Data preliminarily reported in ref. 14

c) Compound 7 showed a peculiar behavior: at low concentrations $\left(10^{-10}-10^{-7} \mathrm{M}\right)$ it behaves as antagonist while it acts as an agonist at higher concentrations $\left(10^{-6}-10^{-4} \mathrm{M}\right)$.

d) $\mathrm{nd}=$ not determined

e) See ref. 38

f) See ref. 49

g) See ref. 47 and 48 .

h) Defined as at least a $0.7 \log$ difference in $\mathrm{pIC}_{50}$ values among the assayed integrins; see ref. 51 . 
The most interesting $\beta$-lactam compounds behaving as integrin ligands in the cell adhesion assays above described, were further characterized in solid-phase competitive integrin binding assays set up for $\alpha_{\mathrm{v}} \beta_{3}, \alpha_{\mathrm{v}} \beta_{5}, \alpha_{\mathrm{v}} \beta_{6}, \alpha_{5} \beta_{1}, \alpha_{\mathrm{IIb}} \beta_{3}$, and $\alpha_{\mathrm{L}} \beta_{2}$, whereas affinity to $\alpha_{4} \beta_{1}$ was evaluated by a scintillation proximity-binding assay (SPA). Interestingly, as reported in Table 2, the assayed compounds showed affinity values and selectivity that agree with the data found in cell adhesion assays reported in Table 1; an exception was $\mathbf{8}$ that, in comparison to cell adhesion assays, was 20 times more potent $v s . \alpha_{v} \beta_{3}$ and 370 times more potent $v s . \alpha_{v} \beta_{5}$ in solid-phase binding assays (Table 2).

Table 2. $\mathrm{IC}_{50}$ values $(\mathrm{nM})^{\mathrm{a}}$ of $\beta$-lactam compounds on RGD-binding and leukocyte integrins.

\begin{tabular}{|c|c|c|c|c|c|c|c|}
\hline \multirow[b]{2}{*}{ Comp. } & \multicolumn{5}{|c|}{ RGD-binding integrins } & \multirow{2}{*}{$\begin{array}{c}\text { Leukocyte } \\
\text { integrin } \\
\alpha_{4} \beta_{1}\end{array}$} & \multirow{2}{*}{$\begin{array}{c}\text { Preferential } \\
\text { selectivity }^{b}\end{array}$} \\
\hline & $\boldsymbol{\alpha}_{\mathrm{v}} \boldsymbol{\beta}_{3}$ & $\boldsymbol{\alpha}_{\mathrm{v}} \boldsymbol{\beta}_{5}$ & $\boldsymbol{\alpha}_{\mathrm{v}} \boldsymbol{\beta}_{6}$ & $\alpha_{5} \beta_{1}$ & $\boldsymbol{\alpha}_{I I b} \beta_{3}$ & & \\
\hline 1 & $5.6 \pm 0.9$ & $3.8 \pm 1.3$ & $80.5 \pm 12.6$ & $5.5 \pm 1.1$ & $>1000$ & $>1000$ & $\alpha_{\mathrm{v}} \beta_{3}, \alpha_{\mathrm{v}} \beta_{5,}, \alpha_{5} \beta_{1}$ \\
\hline 2 & $1.2 \pm 0.3$ & $103.7 \pm 23.2$ & $>1000$ & $>1000$ & $>1000$ & $>1000$ & $\alpha_{\mathrm{v}} \beta_{3}$ \\
\hline 5 & $>1000$ & $>1000$ & $>1000$ & $331 \pm 36$ & $>1000$ & $7.6 \pm 1.3$ & $\alpha_{4} \beta_{1}$ \\
\hline 15 & $9.9 \pm 2.2$ & $>1000$ & $>1000$ & $9.7 \pm 2.4$ & $>1000$ & $498 \pm 27$ & $\alpha_{\mathrm{L}} \beta_{2}{ }^{\mathrm{c}}, \alpha_{\mathrm{v}} \beta_{3}, \alpha_{5} \beta_{1}$ \\
\hline 21 & $>1000$ & $>1000$ & $>1000$ & $5.5 \pm 0.8$ & $>1000$ & $\mathrm{nd}^{\mathrm{d}}$ & $\alpha_{5} \beta_{1}$ \\
\hline 8 & $1.9 \pm 0.6$ & $2.4 \pm 0.8$ & $>1000$ & $>1000$ & $265 \pm 69$ & $>1000$ & $\alpha_{\mathrm{v}} \beta_{3}, \alpha_{\mathrm{v}} \beta_{5}$ \\
\hline 4 & $285 \pm 17$ & $>1000$ & $>1000$ & $114 \pm 9$ & nd & $1.1 \pm 0.1$ & $\alpha_{4} \beta_{1}$ \\
\hline 9 & $>1000$ & $>1000$ & $>1000$ & $>1000$ & nd & $9.8 \pm 0.8$ & $\alpha_{4} \beta_{1}$ \\
\hline 17 & $>1000$ & $>1000$ & $>1000$ & $52.0 \pm 2.6$ & nd & $>1000$ & $\alpha_{5} \beta_{1}$ \\
\hline 19 & $116 \pm 9$ & $634 \pm 28$ & $23.4 \pm 5.3$ & $36.0 \pm 5.7$ & nd & $12.4 \pm 1.1$ & $\alpha_{4} \beta_{1}, \alpha_{v} \beta_{6}, \alpha_{5} \beta_{1}$ \\
\hline 49 & $1.4 \pm 0.4$ & $14.2 \pm 6.3$ & $>1000$ & nd & $>1000$ & nd & \\
\hline
\end{tabular}


a) $\mathrm{IC}_{50}$ for RGD-binding integrins and $\alpha_{\mathrm{L}} \beta_{2}$ was determined by a competitive solid-phase binding assay to specific ligand (fibronectin for $\alpha_{v} \beta_{3}, \alpha_{v} \beta_{6}$, and $\alpha_{5} \beta_{1}$, fibrinogen for $\alpha_{v} \beta_{5}$ and $\alpha_{\mathrm{II}} \beta_{3}$, and ICAM- 1 for $\alpha_{\mathrm{L}} \beta_{2}$ ). IC 50 for $\alpha_{4} \beta_{1}$ was determined by scintillation-proximity assay (SPA). Values represent the mean \pm SD of three independent experiments carried out in duplicate.

b) Defined as at least a $0.7 \log$ difference in $\mathrm{pIC}_{50}$ values among the assayed integrins; see ref. 51.

c) Compound 15 was the unique that retained a relevant $\alpha_{\mathrm{L}} \beta_{2}$ binding affinity $\left(\mathrm{IC}_{50} 6.7 \pm\right.$ $2.5, \mathrm{n}=3$ ).

d) $\mathrm{nd}=$ not determined

With regard to $\alpha_{v} \beta_{3}$ integrin, no structural variation improved fibronectin-mediated cell adhesion, and $\mathbf{1}$ and $\mathbf{2}$ were confirmed to be the most active agonists of this series $v s \alpha_{v} \beta_{3}$. Among the new derivatives, azetidinones $\mathbf{1 5}$ and $\mathbf{8}$, which have either a less basic aniline terminus (15) or a carboxylic acid terminus alone $(\mathbf{8})$, reduced cell adhesion mediated by $\alpha_{\mathrm{v}} \beta_{3}$ integrin, and thus displayed antagonist activity. Compound 7 with an acidic terminus of $\beta$-alanine and an ureido PUPA motif behaves as an antagonist towards $\alpha_{\mathrm{v}} \beta_{3}$ integrin at low concentrations, and as an agonist at higher concentrations. Aizpurua and colleagues have described low molecular weight $\beta$-lactam pseudopeptides which fulfilled several structural requirements to act as antagonists or agonists at $\alpha_{\mathrm{V}} \beta_{3}$ integrin by differently regulating genes known to be related to angiogenesis in an in vitro cell assay. ${ }^{11}$ Interestingly, a shorter acidic side chain, as in $\mathbf{4}$, acts as a low potent antagonist, whereas a longer one, as in $\mathbf{1 9}$, switched the activity to agonism.

As regards solid-phase binding assays, 1, 2, 15, and 8 exhibited a nanomolar activity towards $\alpha_{v} \beta_{3}$ integrin (Table 2). Azetidinone 1 possessed a remarkable affinity towards $\alpha_{v} \beta_{5}, \alpha_{v} \beta_{6}$, and $\alpha_{5} \beta_{1}$ integrin. Compound 2 exhibited an 8.5 times higher activity for $\alpha_{v} \beta_{3}$ integrin in comparison to $\alpha_{\mathrm{v}} \beta_{5}$ and did not recognize the other integrins evaluated in the solid-phase binding assays. 
Azetidinone 8 bounds to $\alpha_{\mathrm{v}} \beta_{3}$ and $\alpha_{\mathrm{v}} \beta_{5}$ integrin in a nanomolar range; 19 exhibited a 96 times lower potency compared to 2 towards $\alpha_{\mathrm{v}} \beta_{3}$ integrin.

Compounds $\mathbf{1}$ and $\mathbf{8}$ acted as agonists in cell adhesion assays towards $\alpha_{\mathrm{v}} \beta_{5}$ integrin (Table 1) and retained a relevant affinity for this integrin in solid-phase binding assays (Table 2); 1 exhibited a similar affinity towards $\alpha_{5} \beta_{1}$ integrin and $\mathbf{2}$ and $\mathbf{1 9}$ were far less active.

With regards to $\alpha_{\mathrm{v}} \beta_{6}$ integrin, $\mathbf{1}$ and $\mathbf{1 9}$ were the most effective in cell adhesion assays: $\mathbf{1}$ behaved as an agonist whereas $\mathbf{1 9}$ was an antagonist (Table 1). This latter compound was the most potent towards $\alpha_{v} \beta_{6}$ integrin albeit it binds to $\alpha_{5} \beta_{1}$ and $\alpha_{4} \beta_{1}$ integrin with similar activities. Solid-phase binding assays confirmed the affinity of 1 and 19 to $\alpha_{v} \beta_{5}$ integrin; both compounds also bind to $\alpha_{v} \beta_{3}, \alpha_{v} \beta_{5}$ and $\alpha_{5} \beta_{1}$ integrin (Table 2).

With regard to $\alpha_{5} \beta_{1}$ integrin, compounds $\mathbf{1 , 2 1}$, and 17 appeared to be the most potent agonists at promoting cell adhesion, with $\mathrm{EC}_{50}$ values of 12.0, 6.7 and $9.9 \mathrm{nM}$, respectively (table 1). Moreover, 21 and 17 were relatively selective agonists for $\alpha_{5} \beta_{1}$ over the other integrins assayed. The inhibition of $\alpha_{5} \beta_{1}$-mediated cell adhesion was observed only at a micromolar range for a few derivatives with a short carboxylic acid terminus on C-4, and a less basic or PUPA residue on the nitrogen $(\mathbf{5}, \mathbf{1 4}$, and $\mathbf{4}$, Table 1$)$. Interestingly, $\mathbf{3}$ and $\mathbf{5}$, despite a low potency for the $\alpha_{5} \beta_{1}$ receptor, showed opposite activities, in that $\mathbf{3}$ was an agonist whereas $\mathbf{5}$ was an antagonist of cell adhesion. A similar result was observed for $\mathbf{2 0}$ and 21: the former, with an aniline residue, was a weak antagonist $\left(\mathrm{IC}_{50}>1000 \mathrm{nM}\right)$ whereas the latter, with a benzylamine terminus, was a strong agonist $\left(\mathrm{EC}_{50}=6.7 \mathrm{nM}\right)($ Table 1$)$.

A more basic amine terminus (benzylamine versus aniline residues) tended to favor agonist behavior (see, for instance, $\mathbf{1}, \mathbf{2}$, and $\mathbf{3}$ vs. 5, 15, and 20, Table 1), although these $\beta$-lactams could 
act as electrostatic clamps for $\alpha_{5} \beta_{1}$ or $\alpha_{v} \beta_{3}$ integrins, like the RGD peptide (see modeling section). On the other hand, the presence of an acidic terminus alone with a suitable chain length could allow a favorable interaction at the MIDAS, which could affect cell adhesion. In fact, esters $10,11,12$, and 13 , which lack these characteristics, were completely inactive toward all the integrins, as were compounds $\mathbf{1 6}$ and $\mathbf{1 8}$ with longer side chains (table 1).

Compounds 1 and 15 displayed a potent binding affinity towards $\alpha_{5} \beta_{1}$ integrin and bind with a similar potency to $\alpha_{v} \beta_{3}$ (Table 2). Furthermore, 21 and 19 displayed high affinity for $\alpha_{5} \beta_{1}$ integrin; however, 21 was inactive towards the other integrins assayed whereas 19 recognized almost of all of them (Table 2).

Apart $\mathbf{8}$, all the selected $\beta$ lactam compounds were inactive for integrin $\alpha_{\mathrm{IIb}} \beta_{3}$. Azetidinone $\mathbf{8}$ showed a low affinity either in the cell adhesion assay $\left(\mathrm{EC}_{50} 311 \mathrm{nM}\right.$, Table 1)), acting as an agonist, and in solid-phase binding assay ( $\mathrm{IC}_{50} 265 \mathrm{nM}$, Table 2)).

We extended our investigation to leukocyte integrins $\alpha_{4} \beta_{1}$ and $\alpha_{\mathrm{L}} \beta_{2}$. Compounds 5 and $\mathbf{4}$ with a short carboxylic acid terminus or either a less basic or no amine residue efficiently interacted with $\alpha_{4} \beta_{1}$ integrin by inhibiting VCAM-1-mediated cell adhesion with $\mathrm{IC}_{50}$ values of 8.8 and $1.39 \mathrm{nM}$, respectively (Table 1). When the amine terminus was replaced with a PUPA residue, we observed increased activities for 4, 9, and $\mathbf{1 9}$ at a nanomolar level. Conversely, compound $\mathbf{9}$, which is a homolog of $\mathbf{4}$ at the $\mathrm{C} 4$, was an effective and very selective agonist of cell adhesion mediated by $\alpha_{4} \beta_{1}$ integrin $\left(\mathrm{EC}_{50}=12.9 \mathrm{nM}\right.$, Table 1$)$, and this activity decreased with an increase in the length of the side chain ( $\mathbf{9}$ vs $\mathbf{1 7}$, Table 1).

In this series of new $\beta$-lactam derivatives, we did not find a correlation between the activities toward $\alpha_{4} \beta_{1}$ and $\alpha_{5} \beta_{1}$ integrins: most of the $\beta$-lactams that were active toward the former integrin 
were inactive toward the latter. Compound $\mathbf{1 9}$ is an exception in this sense, because it showed similar potencies for opposite activities: agonist toward $\alpha_{5} \beta_{1}\left(\mathrm{EC}_{50}=49 \mathrm{nM}\right)$, but antagonist toward $\alpha_{4} \beta_{1}\left(\mathrm{IC}_{50}=17.4 \mathrm{nM}\right)($ Table 1$)$.

Adopting a scintillation proximity-binding assay (SPA), we confirmed that 5, 4, 9 and 19 bind to $\alpha_{4} \beta_{1}$ integrin in a nanomolar range, and that 9 was the most selective recognizing only $\alpha_{4} \beta_{1}$ (Table 2).

With regard to $\beta$-lactam activity toward $\alpha_{L} \beta_{2}$ integrin, only $\mathbf{1 5}$ showed excellent activity as an antagonist at subnanomolar concentrations $\left(\mathrm{IC}_{50}=0.39 \mathrm{nM}\right.$, Table 1), albeit it was not selective relative to the other integrins assayed. Furthermore, 15 was the only $\beta$-lactam that binds to $\alpha_{\mathrm{L}} \beta_{2}$ $\left(\mathrm{IC}_{50} 6.7 \pm 2.5, \mathrm{n}=3\right)$ in solid-phase binding assays.

The abilities of the new $\beta$-lactams acting as integrin agonists to increase cell adhesion were tested in the absence of fibronectin for $\alpha_{5} \beta_{1}$ and $\alpha_{v} \beta_{3}$ or VCAM-1 for $\alpha_{4} \beta_{1}$ integrin. For this purpose, the adhesion of K562, SK-MEL-24 and Jurkat E6.1 cells was evaluated in wells that had been previously coated by passive adsorption with each novel agonist under investigation (2$10 \mu \mathrm{g} / \mathrm{mL}$ ). Regarding $\alpha_{5} \beta_{1}$ integrin, $\beta$-lactam agonists 15, 17, 19, and 21 induced a significant concentration-dependent increase in K562 cell adhesion, as observed for fibronectin (see the Supporting Information, Figure S1 A); we previously demonstrated the same behavior for $\beta$ lactam $\alpha_{5} \beta_{1}$ agonists 1 and $\mathbf{2}^{14}$. Pre-incubation of K562 cells with c(-RGDfV) $(1 \mu \mathrm{M})$, a well known antagonist of RGD integrins, ${ }^{47}$ significantly reduced cell adhesion mediated by azetidinones 15 and 19 but not by 17 and 21 (Supporting Information, Figure S1 A). These results could suggest that $\beta$-lactams 15 and 19 may bind the MIDAS site, an effect prevented by c(-RGDfV). Conversely, $\mathbf{1 7}$ and $\mathbf{2 1}$ might bind to an allosteric site since cell adhesion mediated 
by these compounds was preserved even in the presence of c(-RGDfV). Future studies will better address this hypothesis.

As regards $\alpha_{\mathrm{v}} \beta_{3}$ integrin, SK-MEL-24 cell adhesion was increased in a concentration relatedmanner by $\mathbf{1}$ and $\mathbf{2}$ as well as by fibronectin (see the Supporting Information, Figure S1 B). Preincubation with c(-RGDfV) $(1 \mu \mathrm{M})$ significantly reduced cell adhesion mediated by $\mathbf{1}$ and $\mathbf{2}$, thus suggesting that both molecules may bind to the MIDAS site.

In addition, compound 9 the only $\alpha_{4} \beta_{1}$ agonist, significantly augmented Jurkat E6.1 cell adhesion, similarly to VCAM-1 (Supporting Information, Figure S1 C). Pre-incubation with a neutralizing antibody against the $\alpha_{5}, \alpha_{\mathrm{v}}$, or $\alpha_{4}$ integrin subunits $(10 \mu \mathrm{g} / \mathrm{mL})$ blocked the augmented adhesion of K562 or SK-MEL-24 or Jurkat E6.1 cells induced by $\beta$-lactam agonists 1, 2, 15, 17, 19, and 21, respectively (Supporting Information, Figure S1). These results are consistent with the notion that cell adhesion mediated by the new $\beta$-lactam agonists effectively and specifically involves $\alpha_{5} \beta_{1}, \alpha_{v} \beta_{3}$ and $\alpha_{4} \beta_{1}$ integrins, respectively.

We and others have previously demonstrated that the protein kinase $\mathrm{C}$ (PKC) activator PMA (phorbol myristate acetate), which induces megakaryocytic differentiation of the human erythroleukemia cell line K562 (which mainly expresses $\alpha_{5} \beta_{1}$ integrin), increases $\alpha_{\mathrm{IIb}} \beta_{3}$ integrin expression, ${ }^{14,52}$ and this may represent an additional target of these novel $\beta$-lactams. To elucidate the contribution of $\alpha_{\mathrm{IIb}} \beta_{3}$ integrin to cell adhesion induced by agonists $15,17,19$, and 21 , the selective $\alpha_{\mathrm{IIb}} \beta_{3}$ antagonist Tirofiban (51) (5 and $10 \mu \mathrm{M}$ ) was used. Interestingly, 51 did not modify cell adhesion induced by $\mathbf{1 5 , 1 7}$ or 19 (Supporting Information, Figure S1 D), which, at least in this cell line, seems to be mediated only by $\alpha_{5} \beta_{1}$ and not by $\alpha_{\mathrm{IIb}} \beta_{3}$ integrin. On the contrary, $\mathbf{5 1}$ partially blocked K562 adhesion mediated by compound $\mathbf{2 1}$, meaning that both $\alpha_{5} \beta_{1}$ 
and $\alpha_{\mathrm{II}} \beta_{3}$ integrins may contribute to cell adhesion induced by this $\beta$-lactam (Supporting Information, Figure S1 D).

\section{Effects of selected $\beta$-lactams on integrin-mediated ERK phosphorylation.}

Intracellular signaling generated by the interaction of components of the extracellular matrix (ECM) with selected integrins involves second messengers, ${ }^{53}$ including extracellular signalregulated kinases 1 and $2($ ERK1/2).

Since this pathway is impaired in SK-MEL-24 cells, ${ }^{54}$ to investigate the effects of the compounds that had the greatest effects on $\alpha_{\mathrm{v}} \beta_{3}$-mediated signaling activation ( 2 and 15), we used HEK293 cells that had been transfected with plasmids expressing the coding sequences of $\alpha_{\mathrm{v}}$ and $\beta_{3}$ integrin $\left(\right.$ HEK293 $\left.+\alpha_{\mathrm{v}} \beta_{3}\right)$. $\beta$-Lactam agonist 2 significantly increased ERK1/2 phosphorylation in a concentration-dependent manner in HEK293+ $\alpha_{v} \beta_{3}$ (Figure 4 A). Moreover, azetidinone 15, which behaved as an antagonist towards $\alpha_{\mathrm{v}} \beta_{3}$ integrin, strongly prevented ERK1/2 activation induced by fibronectin (Figure 4 B). 

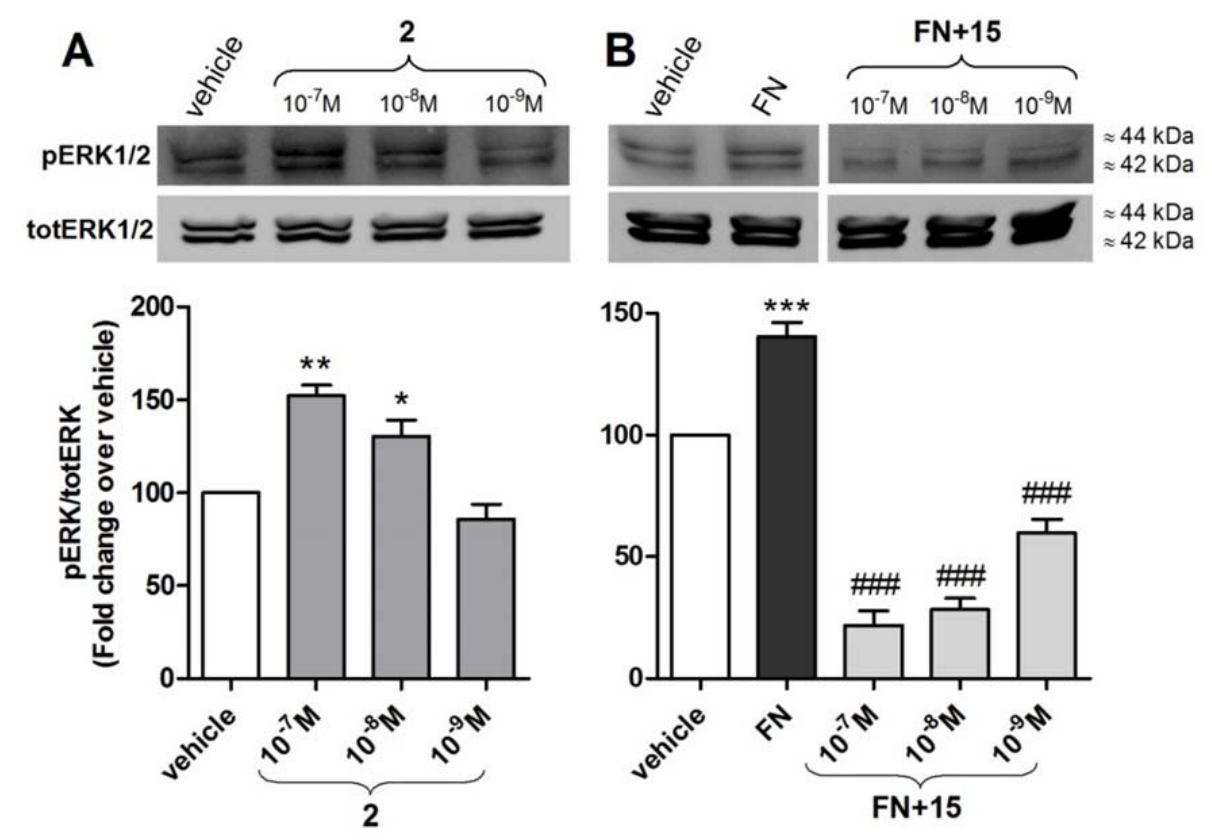

Figure 4. Effects of selected $\beta$-lactams on ERK1/2 phosphorylation mediated by $\alpha_{v} \beta_{3}$ integrin expressed in HEK293 $+\alpha_{v} \beta_{3}$ cells. A. Compound 2 significantly increased, in a concentration dependent manner, ERK1/2 phosphorylation. B. Compound $\mathbf{1 5}$ prevented FN-induced phosphorylation of ERK1/2 in a concentration-dependent manner. Representative Western blots show that control cells plated on FN had a much stronger signal for pERK1/2 than vehicletreated cells (vehicle). Densitometric analysis of the bands is shown (mean \pm SEM; $n=6$ ); the amount of $\mathrm{pERK} 1 / 2$ is normalized to that of totERK1/2. ${ }^{*} \mathrm{p}<0.05, * * \mathrm{p}<0.01,{ }^{* * *} \mathrm{p}<0.001$ versus vehicle; \#\#\#p < 0.001 versus FN (Newman-Keuls test after ANOVA).

The effects of $\beta$-lactams that most strongly affected $\alpha_{5} \beta_{1}$ integrin-mediated cell adhesion were evaluated on ERK1/2 phosphorylation in K562 cells. Selected azetidinones that behaved as agonists in the cell adhesion assay, i.e., 15, 17, 19, and 21, significantly increased ERK1/2 
phosphorylation when added alone to cells; moreover, 17, 19, and 21 increased ERK1/2 phosphorylation in a concentration-dependent manner (Figure $5 \mathrm{~A}$ and B). Otherwise, the $\alpha_{5} \beta_{1}$ integrin antagonist 4 reduced ERK1/2 phosphorylation induced by fibronectin in a concentrationrelated manner (Figure $5 \mathrm{C}$ ).

A
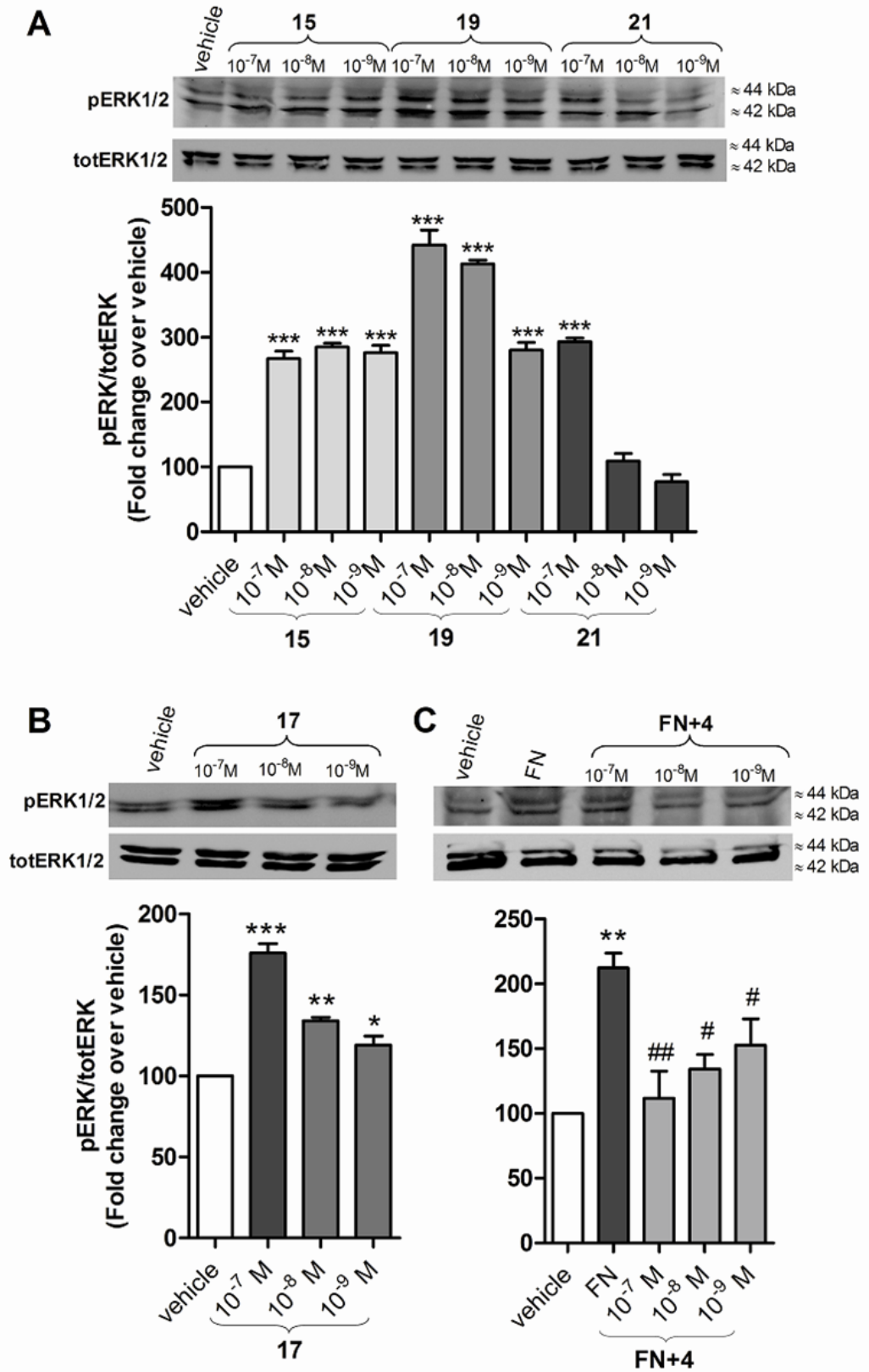
Figure 5. Effects of selected $\beta$-lactams on ERK1/2 phosphorylation mediated by $\alpha_{5} \beta_{1}$ integrin expressed in K562 cells. A, B: agonists 15, 17, 19 and 21 significantly increased ERK1/2 phosphorylation. C: Compound 4 prevented FN-induced phosphorylation of ERK1/2 in a concentration-dependent manner. Representative Western blots show that control cells plated on FN had a much stronger signal for pERK1/2 than vehicle-treated cells (vehicle). Densitometric analysis of the bands is shown (mean \pm SEM; $n=6$ ); the amount of $p E R K 1 / 2$ is normalized to that of totERK1/2. ${ }^{*} \mathrm{p}<0.05,{ }^{* *} \mathrm{p}<0.01,{ }^{* * *} \mathrm{p}<0.001$ versus vehicle; $\# \mathrm{p}<0.05, \# \# \mathrm{p}<0.01$ versus FN (Newman-Keuls test after ANOVA).

The $\beta$-lactam 9, a selective $\alpha_{4} \beta_{1}$ integrin agonist, when added alone to Jurkat E6.1 cells, strongly and significantly increased ERK1/2 phosphorylation in comparison to vehicle-treated cells (Figure 6 A). In Jurkat E6.1 cells exposed to VCAM-1, a significant increase in ERK1/2 phosphorylation was detected (Figure $6 \mathrm{~B}$ and $\mathrm{C}$ ), and pre-incubation with $\beta$-lactam antagonists 4, 5, and 19 caused a significant decrease in VCAM-1-mediated ERK1/2 phosphorylation (Figure $6 \mathrm{~B}$ and C); azetidinones 5 and $\mathbf{1 9}$ were effective in a concentration-dependent manner (Figure 6).

Azetidinone 4 was more effective in preventing VCAM-1-induced ERK1/2 phosphorylation at $10^{-9}-10^{-7} \mathrm{M}$ (Figure 6); lower concentrations $\left(10^{-12}-10^{-10} \mathrm{M}\right)$ displayed a concentrationdependent inhibition of ERK1/2 activation by VCAM-1 (Supporting Information, Figure S2 ). 

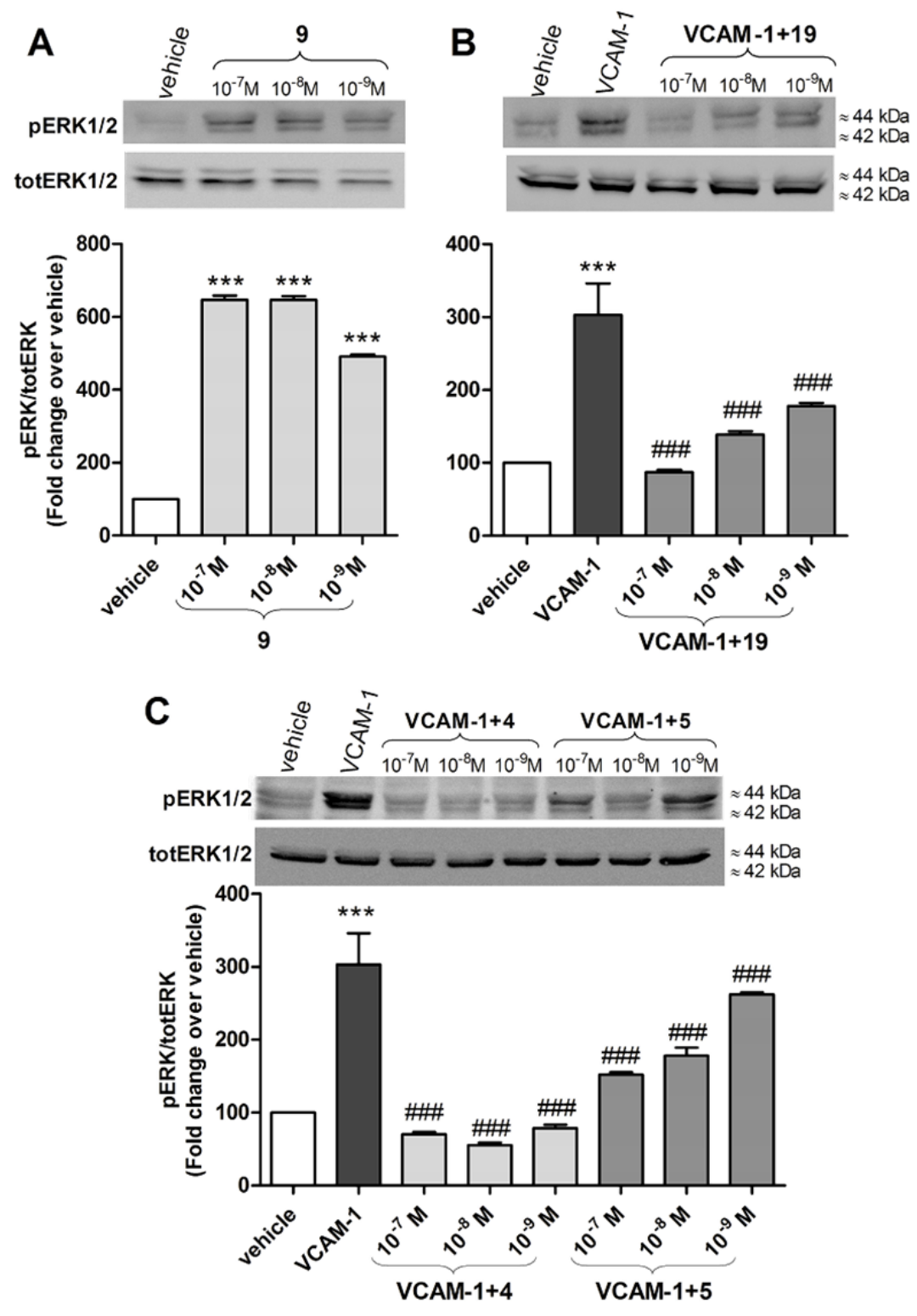

Figure 6. Effects of selected $\beta$-lactams on ERK1/2 phosphorylation mediated by $\alpha_{4} \beta_{1}$ integrin expressed in Jurkat E6.1 cells. A: $\beta$-lactam agonist 9 significantly increased ERK1/2 phosphorylation. B, C: azetidinones 4, 5, and 19 prevented VCAM-1-induced phosphorylation of ERK1/2 in a concentration-dependent manner. Representative Western blots show that control cells plated on VCAM-1 had a much stronger signal for pERK1/2 than vehicle-treated cells (vehicle). Densitometric analysis of the bands is shown (mean \pm SEM; $n=6$ ); the amount of 
pERK1/2 is normalized to that of totERK1/2.***p $<0.001$ versus vehicle; \#\#\#p $<0.001$ versus VCAM-1 (Newman-Keuls test after ANOVA).

ICAM-1-exposure induced a significant increase in ERK1/2 phosphorylation in Jurkat E6.1 cells by activating $\alpha_{\mathrm{L}} \beta_{2}$ integrin, ${ }^{49}$ and azetidinone 15, a $\alpha_{\mathrm{L}} \beta_{2}$ antagonist, significantly prevented ICAM-1-induced ERK1/2 activation in a concentration-dependent manner (Figure 7).

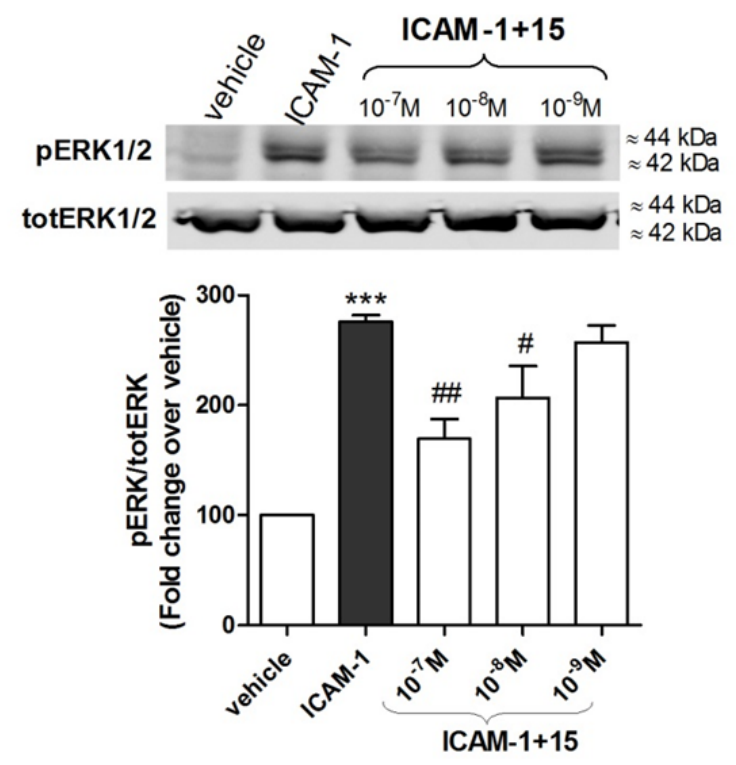

Figure 7. Effects of a selected $\beta$-lactam on ERK1/2 phosphorylation mediated by $\alpha_{\mathrm{L}} \beta_{2}$ integrin expressed in Jurkat E6.1 cells. $\alpha_{\mathrm{L}} \beta_{2}$ antagonist 15 significantly prevented ICAM-1-induced phosphorylation of ERK1/2 in a concentration-dependent manner. Representative Western blots show that control cells plated on ICAM-1 had a much stronger signal for $\mathrm{pERK} 1 / 2$ than vehicletreated cells (vehicle). Densitometric analysis of the bands is shown (mean \pm SEM; $n=4$ ); the amount of $\mathrm{pERK} 1 / 2$ is normalized to that of totERK1/2.***p $<0.001$ versus vehicle; $\# \mathrm{p}<0.05$, $\# \# \mathrm{p}<0.01$ versus ICAM-1 (Newman-Keuls test after ANOVA). 


\section{$\beta$-Lactam binding to $\alpha_{4} \beta_{1}$ integrin modulates HUTS-21 epitope exposure in Jurkat E6.1 cells.}

Integrins exist in three major conformations: an inactive or bent conformation, an intermediateactivity conformation and a high-activity open conformation. ${ }^{55,56}$ Conformational changes in integrin subunits can be monitored using conformation-specific antibodies that recognize a specific epitope that is exposed only in a defined structural conformation. ${ }^{57}$

To determine whether the binding of these new $\beta$-lactams to $\alpha_{4} \beta_{1}$ integrin alters its conformation, we used the HUTS-21(PE) monoclonal antibody (mAb), comprising the fluorophore reporter phycoerithrin (PE), that recognizes a LIBS (ligand-induced binding site) epitope that is masked on inactive integrin but is exposed upon agonist binding or partial integrin activation. The epitope recognized by HUTS- 21 has been mapped to the hybrid domain of $\beta_{1}$ integrin. ${ }^{58}$ This mAb was added to the cells as described under material and methods, and cells were then analyzed by flow cytometry. As expected, the binding of VCAM-1, the $\alpha_{4} \beta_{1}$ endogenous ligand, induced a conformational rearrangement in the $\beta_{1}$ subunit that resulted in exposure of the HUTS21 epitope and increased antibody binding (Figure 8). Similarly, agonist 9 significantly increased HUTS-21 antibody binding in a concentration-dependent manner. The $\alpha_{4} \beta_{1}$ antagonists 4 and 5 significantly and in a concentration-related manner reduced the exposure of HUTS-21 epitope measured as mAb binding (Figure 8). 


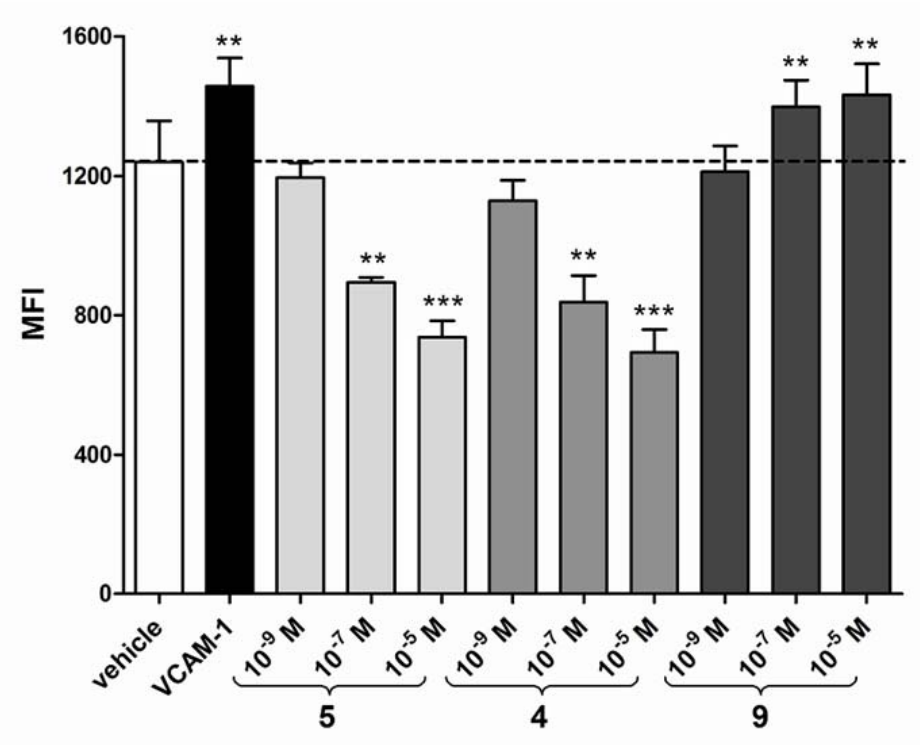

Figure 8. Binding of HUTS-21 antibody to Jurkat E6.1 cells in the presence of different concentrations of the new $\beta$-lactams. Jurkat E6.1 cells were incubated with the compounds that had the greatest effects on $\alpha_{4} \beta_{1}$ integrin $(\mathbf{4}, \mathbf{5}$ and 9), and HUTS-21 mAb was then added. Flow cytometry analysis of Jurkat E6.1 cells was performed to measure the effects of selected $\beta$ lactam agonists and antagonists on exposure of the HUTS-21 epitope. Antagonists 4 and 5 significantly reduced exposure of the HUTS-21 epitope, while $\beta$-lactam agonist 9 increased the binding of HUTS-21 mAb to Jurkat E6.1 cells in a concentration-dependent manner. Results are expressed as mean fluorescence intensity $(\mathrm{MFI}) \pm \mathrm{S}$. E. M. from four independent experiments carried out in duplicate. MFI values for respective isotype control mAb were set to $0 .{ }^{* *} \mathrm{p}<$ $0.01, * * * \mathrm{p}<0.001$ versus vehicle (Newman-Keuls test after ANOVA).

Taken together, these data suggest that novel $\beta$-lactams acting as $\alpha_{4} \beta_{1}$ agonists may induce changes in the integrin conformation, leading to its activation, while $\alpha_{4} \beta_{1}$ antagonists may promote inactive or intermediate-activity conformations. 


\section{Molecular Modeling}

The binding mode of representative $\beta$-lactam derivatives to the $\alpha_{\mathrm{v}} \beta_{3}$ integrin was investigated by a docking approach that was previously developed and successfully applied to the study of small libraries of cyclic and linear RGD peptidomimetics. ${ }^{39,59,60}$ The Glide ${ }^{61}$ program V4.5 was used for docking calculations (see the Experimental Section for computational details) and the crystal structure of the extracellular segment of integrin $\alpha_{v} \beta_{3}$ in a complex with the cyclic pentapeptide Cilengitide (PDB code $1 \mathrm{~L} 5 \mathrm{G})^{62}$ was used as a reference model for interpretation of the results.

The Glide docking protocol was applied to $\beta$-lactam derivatives $\mathbf{1}$ and $\mathbf{1 5}$, which contain the benzylamine and aniline basic moiety, respectively, and the same $\mathrm{C}-4$ acetic acid residue to generate computational models of interaction with the ligand-binding site of the $\alpha_{\mathrm{v}} \beta_{3}$ integrin. Although we cannot discuss the specific role of a more basic amine terminus (benzylamine versus aniline residues) in favoring agonist behavior on the basis of rigid-protein docking calculations, we can examine the effect of the basic moiety on the ability of the ligand to form an electrostatic clamp and reproduce the crystallographic binding mode of Cilengitide. The enantiomerically pure compound 5, bearing a C-4 carboxylic acid and an aniline group, was included in the investigation to gain insight into the effect of the distance between the pharmacophoric groups.

Docking runs starting from both enantiomers of compound $\mathbf{1}$ produced poses that conserved the key polar interactions observed in the X-ray complex. In the calculated poses, the ligand carboxylate group is coordinated to the metal cation in the metal ion-dependent adhesion site (MIDAS) region of the $\beta_{3}$ subunit, and the ligand benzylamine moiety forms salt bridge/H-bond 
interactions with the negatively charged side chain of Asp218 in the $\alpha_{v}$ subunit, although there is no fit with the Arg guanidinium group of Cilengitide (Figure 9). Further stabilizing interactions occur in docking poses of compound 1, involving the formation of hydrogen bonds between the ligand carboxylate group and the backbone amide hydrogen of Asn215 and Tyr122 in the $\beta$ unit, and between the ligand $\beta$-lactam carbonyl and the $\beta_{3}$-Arg214 side chain. Ring-stacking or a Tshaped interaction between the ligand aromatic group and the $\alpha_{\mathrm{v}}$-Tyr178 side chain is also observed in the binding modes calculated for compound $\mathbf{1}$.

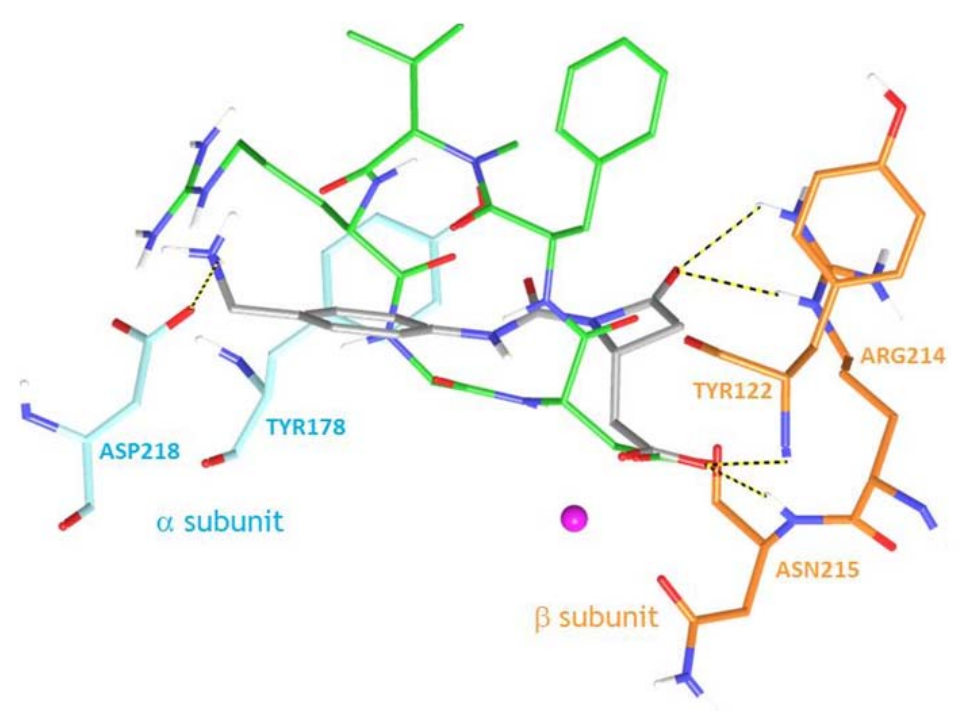

Figure 9. Docking pose of compound $(R)-\mathbf{1}$ (grey carbon atoms) in the crystal structure of the extracellular domain of $\alpha_{\mathrm{v}} \beta_{3}$ integrin ( $\alpha$ unit cyan, $\beta$ unit orange) overlaid on the bound conformation of Cilengitide (green carbon atoms). Only selected integrin residues involved in interactions with the ligand are shown. The metal ion at MIDAS is shown as a magenta CPK sphere. Non-polar hydrogens are hidden for clarity, while intermolecular hydrogen bonds are shown as dashed lines (H-bond $\mathrm{H}-\mathrm{O}$ distance between the ligand basic moiety and the avAsp218 carboxylate $=1.9 \AA$ ) 
Docking runs starting from the two enantiomers of compound $\mathbf{1 5}$ produced rather different results. In the calculated poses of $(R)-\mathbf{1 5}$, the acid and basic pharmacophoric groups act like an electrostatic clamp and interact with charged regions of the receptor binding site. Nevertheless, a poor fit with the receptor-bound structure of Cilengitide is observed, mainly for the aniline basic moiety (Figure 10), which forms a distorted H-bond with the negatively charged carboxylate of $\alpha_{\mathrm{v}}$-Asp218. Similar to the observations for compound $\mathbf{1}$, one carboxylate oxygen of $(R)-\mathbf{1 5}$ is coordinated to the MIDAS metal cation, while the second carboxylate oxygen forms H-bonds with the backbone amides of Asn215 and Tyr122 in the $\beta$ unit. Further stabilizing interactions observed in the binding modes of $(R)-\mathbf{1 5}$ involve a $\mathrm{H}$-bond between the ligand $\beta$-lactam carbonyl and the $\beta_{3}$-Arg214 side chain, and ring-stacking between the ligand aromatic group and the $\alpha_{v^{-}}$ Tyr178 side chain.

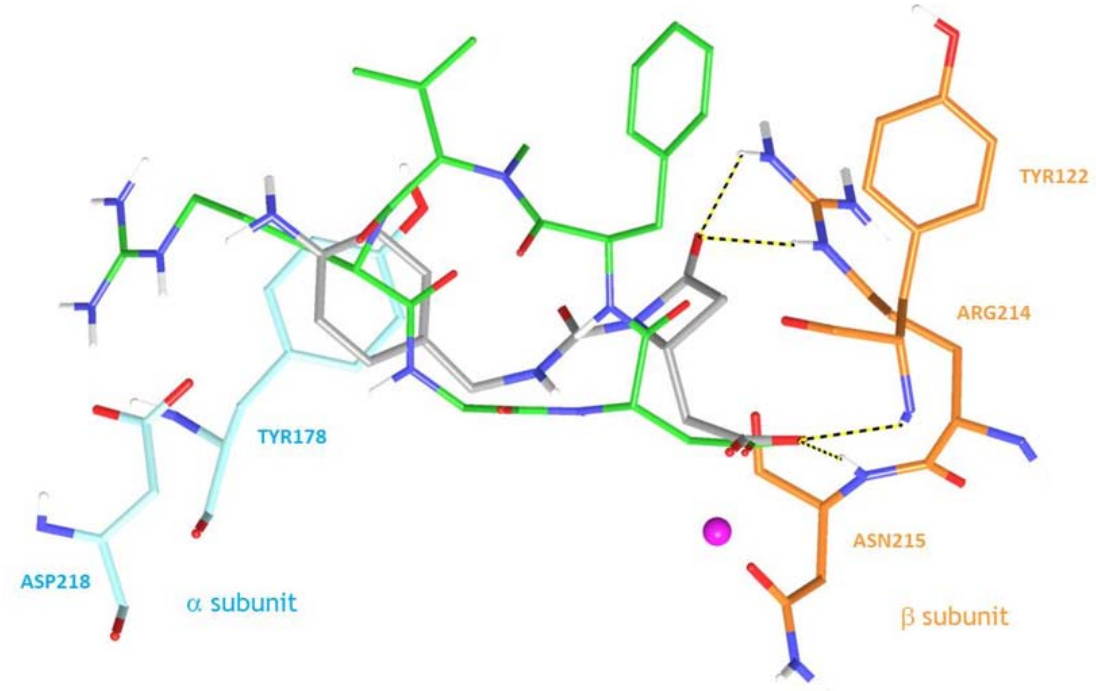

Figure 10. Docking pose of compound $(R)-\mathbf{1 5}$ (grey carbon atoms) in the crystal structure of the extracellular domain of $\alpha_{v} \beta_{3}$ integrin ( $\alpha$ unit cyan, $\beta$ unit orange) overlaid on the bound 
conformation of Cilengitide (green carbon atoms). Only selected integrin residues involved in interactions with the ligand are shown. The metal ion at MIDAS is shown as a magenta CPK sphere. Non-polar hydrogens are hidden for clarity and intermolecular hydrogen bonds are shown as dashed lines (H-bond H-O distance between the ligand basic moiety and the $\alpha \mathrm{V}$ Asp218 carboxylate $=3.1 \AA$ )

In the calculated poses of $(S)-\mathbf{1 5}$, the electrostatic clamp is often lost and the ligand engages in interactions only with the $\beta$-subunit. In particular, the coordination of the ligand carboxylate to the MIDAS cation is retained, while the aniline moiety moves toward the $\beta$-chain, driven by hydrophobic interactions.

The docking results for compound $\mathbf{5}$ reveal poor binding ability, in terms of both ligand-receptor interactions and docking score. The shorter distance between the pharmacophoric acid and basic groups (about $11 \AA$ in the docking poses of isomers $(R)-\mathbf{1}$ and $(R)-\mathbf{1 5}$ shown in Figures 9 and 10 vs. about $9 \AA$ in the poses of compound $\mathbf{5}$ makes this ligand the worst mimic of the Cilengitide binding mode.

\section{CONCLUSION}

We developed a small library of $\beta$-lactam derivatives that were specifically designed by a structure-based strategy to target RGD-binding and leukocyte integrins. We obtained selective and potent agonists that could promote cell adhesion mediated by $\alpha_{v} \beta_{3}, \alpha_{v} \beta_{5}, \alpha_{5} \beta_{1}$, or $\alpha_{4} \beta_{1}$ integrin and antagonists that were selective for these RGD-binding integrins as well as antagonists that 
bound to $\alpha_{\mathrm{v}} \beta_{6}, \alpha_{4} \beta_{1}$ and $\alpha_{\mathrm{L}} \beta_{2}$ integrins. A benzylamine terminus appeared to favor agonist behavior and this supports the hypothesis that these new $\beta$-lactams could act as an electrostatic clamp for $\alpha_{5} \beta_{1}$ or $\alpha_{\mathrm{v}} \beta_{3}$ integrins, as suggested by molecular docking studies at $\alpha_{\mathrm{v}} \beta_{3}$ receptors. Further investigation of selected $\beta$-lactam compounds showed that they could influence intracellular signaling activated by endogenous integrin agonists. Only a few studies have focused on the discovery of integrin agonists that may be useful in several clinical conditions. ${ }^{31-}$ ${ }^{34}$ Interestingly, one of the first studies on RGD mimetic peptides found that they may act as partial agonists as well as competitive antagonists of integrin $\alpha_{\mathrm{IIb}} \beta_{3}$ and proposed that the structural characteristics for peptide activation and the inhibition of endogenous ligand binding are analogous. ${ }^{35}$ Recently, Van Agthoven et al. have described a $10 \mathrm{kDa}$ wild type fibronectin (wtFN10) that binds and activates $\alpha_{\mathrm{V}} \beta_{3}$ integrin whereas a high-affinity mutant (hFN10), carrying substitutions adjacent to the RGD sequence, behaves as a pure antagonist as it favors an inactive conformation of the integrin. Following selective integrin mutations, hFN10 is switched to a partial agonist. ${ }^{63}$ Similar conclusions may apply to the present $\beta$-lactams, which bind with good affinity to their target integrins and induce a change in conformation that may facilitate cell signaling in the case of agonists or prevent the binding of endogenous ligands in the case of antagonists. 


\section{Experimental section}

General information

Commercial reagents were used as received without additional purification. ${ }^{1} \mathrm{H},{ }^{19} \mathrm{~F}$ and ${ }^{13} \mathrm{C}$ NMR spectra were recorded with an INOVA 400 or a GEMINI 200 instrument with a $5 \mathrm{~mm}$ probe. All chemical shifts are quoted relative to deuterated solvent signals ( $\delta$ in ppm and $J$ in Hz). Polarimetric Analyses were conducted on Unipol L 1000 “Schmidt-Haensch" Polarimeter at $598 \mathrm{~nm}$. FTIR spectra: Brucker Alpha instrument, measured as films between $\mathrm{NaCl}$ plates, wave numbers are reported in $\mathrm{cm}^{-1}$. The purities of the target compounds were assessed as being $>95 \%$ using HPLC-MS. HPLC-MS: Agilent Technologies HP1100 instrument, equipped with a ZOBRAX-Eclipse XDB-C8 Agilent Technologies column; mobile phase: $\mathrm{H}_{2} \mathrm{O} / \mathrm{CH}_{3} \mathrm{CN}, 0.4$ $\mathrm{mL} / \mathrm{min}$, gradient from 30 to $80 \%$ of $\mathrm{CH}_{3} \mathrm{CN}$ in $8 \mathrm{~min}, 80 \%$ of $\mathrm{CH}_{3} \mathrm{CN}$ until $25 \mathrm{~min}$, coupled with an Agilent Technologies MSD1100 single-quadrupole mass spectrometer, full scan mode from $\mathrm{m} / \mathrm{z}=50$ to 2600 , in positive or negative ion mode. Elemental analysis were performed on a Thermo Flash 2000 CHNS/O Analyzer.

$\beta$-Lactams 13, 22, 35 and 44 were synthesized according to a previously reported procedure. ${ }^{14}$ LC-MS and NMR monitoring indicated no degradation for all new $\beta$-lactam molecules stored as pure compounds at $4{ }^{\circ} \mathrm{C}$ for up to 4 months. As models, we studied the stabilities of compounds 2 and 4 in buffered water solutions at $\mathrm{pH}=7.4$ at $30{ }^{\circ} \mathrm{C}$ and in serum at $30{ }^{\circ} \mathrm{C}$ (see Supporting Information). 
Isocyanate 23 was synthesized accordingly to a reported procedure, ${ }^{14}$ starting from tert-butyl (4(aminomethyl)phenyl)carbamate, which in turns was prepared as in ref. 64. Isocyanate 34 was synthesized according to a previously reported procedure. ${ }^{14}$

\section{General procedure for $N$-acylation of $\beta$-lactams (GP1A and GP1B)}

GP1A: A solution of sodium bis(trimethylsilyl)amide (NaHMDSA) (1.0 M in THF, 1.1 equiv) was added dropwise to a solution of the starting $\beta$-lactam 22 or $\mathbf{1 3}$ (1 equiv) in anhydrous THF $(9 \mathrm{~mL} / \mathrm{mmol})$ at $-78^{\circ} \mathrm{C}$ under a nitrogen atmosphere. The mixture was stirred for $15 \mathrm{~min}$, then a solution of freshly prepared isocyanate $\mathbf{2 3}$ or $\mathbf{3 4}$ (1.5 equiv) in anhydrous THF ( $1 \mathrm{~mL}$ ) was added dropwise. After completion (TLC monitoring, $30 \mathrm{~min}$ ) the mixture was quenched with a saturated solution of $\mathrm{NH}_{4} \mathrm{Cl}$ and extracted with $\mathrm{AcOEt}(10 \mathrm{~mL})$ and with $\mathrm{CH}_{2} \mathrm{Cl}_{2}(2 \times 10 \mathrm{~mL})$. The combined organic extracts were dried over $\mathrm{Na}_{2} \mathrm{SO}_{4}$, concentrated in vacuum and purified by flash-chromatography affording the desired derivatives $\mathbf{2 4}$ or $\mathbf{3 1}$.

GP1B: The starting beta-lactam 22, 29, 30 or 13 (1 equiv) was dissolved in anhydrous $\mathrm{CH}_{3} \mathrm{CN}$ ( $1 \mathrm{~mL}$ ) under a nitrogen atmosphere. Anhydrous and finely ground $\mathrm{K}_{2} \mathrm{CO}_{3}$ (1.5 equiv) was added, followed by a dropwise addition of the commercially available $o$-tolyl- or benzyl isocyanate (1.2 equiv). The mixture was stirred at room temperature until a complete consumption of the starting beta-lactam (about $2 \mathrm{~h}$, TLC monitoring) and then quenched with a saturated solution of $\mathrm{NH}_{4} \mathrm{Cl}$. The solvent was reduced under vacuum and the residual aqueous solution was extracted with $\mathrm{CH}_{2} \mathrm{Cl}_{2}(3 \times 10 \mathrm{~mL})$ The organic layers were collected, dried over $\mathrm{Na}_{2} \mathrm{SO}_{4}$, concentrated in vacuum and purified by flash-chromatography affording the desired Nacylated beta-lactam 26, 10, 11, 12, or 33). 


\section{General procedure for hydrogenolysis (GP2)}

A $\beta$-lactam benzyl ester (1 equiv) $(24,26,27,28,13,12,31,33,37,38,39,40,42$ or 45 ) was dissolved in a mixture of THF and $\mathrm{CH}_{3} \mathrm{OH}(22 \mathrm{~mL} / \mathrm{mmol}, 1: 1 \mathrm{v} / \mathrm{v})$ and $\mathrm{Pd}$ on $\mathrm{C}(10 \% \mathrm{w} / \mathrm{w})$ was added. The solution was then stirred under $\mathrm{a}_{2}$ atmosphere $(1 \mathrm{~atm})$ at room temperature. After a complete consumption of the starting material (TLC monitoring, $2 \mathrm{~h}$ ) the reaction mixture was filtered through celite and concentrated in vacuum. The crude was then triturated with few drops of pentane to afford the desired carboxylic acid $(25,4,6,7,8,9,32,14,16,17,19,41,43$ or 46$)$.

\section{General procedure for N-Boc-deprotection (GP3)}

A $N$-Boc-protected $\beta$-lactam (1 equiv) $(25,32,35,41,43$ or 46$)$ was dissolved in $\mathrm{CH}_{2} \mathrm{Cl}_{2}(18.5$ $\mathrm{mL} / \mathrm{mmol}$ ) under a nitrogen atmosphere and trifluoroacetic acid (TFA) (4 equiv) was added dropwise at $0^{\circ} \mathrm{C}$. If necessary, a new TFA aliquot (4 equiv) was added after 30 min until a complete conversion, HPLC monitoring). The solvent was removed under reduced pressure and the crude was triturated with few drops of pentane the resulting deprotected compound was thus obtained $(5,15,36,18,20$ or 21$)$.

\section{(S)-4-oxo-(o-tolylcarbamoyl)azetidine-2-carboxylic acid (4)}

Following GP2 compound 26 (115 mg, $0.34 \mathrm{mmol})$ yielded compound 4 as a white solid (83 mg, 99\%). IR (film, $\mathrm{cm}^{-1}$ ) 3339, 1787, 1755, 1737; $\mathrm{Mp} 121-124^{\circ} \mathrm{C} ;[\alpha]^{20}=-15\left(\mathrm{c}=1.00, \mathrm{CH}_{2} \mathrm{Cl}_{2}\right)$; ${ }^{1} \mathrm{H}$ NMR (400 MHz, CD $\left.{ }_{3} \mathrm{OD}\right) \delta(\mathrm{ppm}) 2.30(\mathrm{~s}, 3 \mathrm{H}), 3.13(\mathrm{dd}, J=2.8,15.8 \mathrm{~Hz}, 1 \mathrm{H}), 3.52(\mathrm{dd}, J=$ 6.4, $15.8 \mathrm{~Hz}, 1 \mathrm{H}), 4.52-4.56(\mathrm{~m}, 1 \mathrm{H})(\mathrm{d}, J=3.6 \mathrm{~Hz}, 1 \mathrm{H}), 7.05-7.08(\mathrm{~m}, 1 \mathrm{H}), 7.17-7.24(\mathrm{~m}$, 
2H), $7.76(\mathrm{~d}, J=8.0 \mathrm{~Hz}, 1 \mathrm{H}) ;{ }^{13} \mathrm{C} \mathrm{NMR}\left(100 \mathrm{MHz}, \mathrm{CDCl}_{3}\right) \delta(\mathrm{ppm}) 17.5,41.2,49.3,121.5$, 125.0, 126.7, 128.1, 130.4, 134.5, 147.7, 165.5, 171.8; ESI-MS m/z 247 [M-H]'. Found C, 57.97; H, 5.02; N, 11.21\%; $\mathrm{C}_{12} \mathrm{H}_{12} \mathrm{~N}_{2} \mathrm{O}_{4}$ requires C, 58.06; $\mathrm{H}, 4.87 ; \mathrm{N}, 11.29 \%$.

(S)-4-(2-carboxy-4-oxoazetidine-1-carboxamidomethyl) benzenaminium 2,2,2-trifluoroacetate (5)

Following GP3, compound 25 (35 mg, $0.96 \mathrm{mmol})$ was treated with TFA (137 $\mu \mathrm{L}, 1.82 \mathrm{mmol}$, 19 equiv) yielding compound 5 (36 mg, 99\%) as a waxy solid. IR (film, $\mathrm{cm}^{-1}$ ) 3362, 1780, 1698, $1677 ;[\alpha]^{20}{ }_{\mathrm{D}}=-3\left(\mathrm{c}=0.86, \mathrm{CH}_{3} \mathrm{OH}\right) ;{ }^{1} \mathrm{H}$ NMR $\left(400 \mathrm{MHz}, \mathrm{CD}_{3} \mathrm{OD}\right) \delta(\mathrm{ppm}) 3.04(\mathrm{dd}, J=2.8$, $15.8 \mathrm{~Hz}, 1 \mathrm{H}), 3.44(\mathrm{dd}, J=6.4,15.8 \mathrm{~Hz}, 1 \mathrm{H}), 4.45-4.48(\mathrm{~m}, 3 \mathrm{H}), 7.36(\mathrm{~d}, J=8.0 \mathrm{~Hz} ; 2 \mathrm{H}) 7.49$ $(\mathrm{d}, J=8.0 \mathrm{~Hz}, 2 \mathrm{H}) ;{ }^{13} \mathrm{C} \mathrm{NMR}\left(100 \mathrm{MHz}, \mathrm{CD}_{3} \mathrm{OD}\right) \delta(\mathrm{ppm}) 42.0,43.6,50.2,118.4$ (q, $J_{I C F}=$ $300.0 \mathrm{~Hz}), 124.2,130.0,131.1,141.2,151.8,162.4\left(\mathrm{q}, J_{2 C F}=35.6 \mathrm{~Hz}\right), 166.6,172.9 ;{ }^{19} \mathrm{~F} \mathrm{NMR}$ (375 MHz, $\left.\mathrm{CD}_{3} \mathrm{OD}\right) \delta$ (ppm) -77.1; ESI-MS m/z $264[\mathrm{M}-\mathrm{TFA}+\mathrm{H}]^{+}, 281\left[\mathrm{M}-\mathrm{TFA}+\mathrm{H}_{2} \mathrm{O}\right]^{+}$. Found C, 44.44; H, 3.81; N, $10.91 \% ; \mathrm{C}_{14} \mathrm{H}_{14} \mathrm{~F}_{3} \mathrm{~N}_{3} \mathrm{O}_{6}$ requires $\mathrm{C}, 44.57 ; \mathrm{H}, 3.74 ; \mathrm{N}, 11.14 \%$.

\section{(S)-(4-oxo-1-(o-tolylcarbamoyl)azetidine-2-carbonyl)glycine (6)}

Following GP2 compound 27 (29 mg, $0.70 \mathrm{mmol})$ yielded compound $\mathbf{6}$ as a white solid $(21 \mathrm{mg}$, 99\%). Mp $190-192^{\circ} \mathrm{C}$; IR (film, $\left.\mathrm{cm}^{-1}\right) 3356,1778,1737,1690,1674 ;[\alpha]^{20}{ }_{\mathrm{D}}=-11(\mathrm{c}=1.05$, $\left.\mathrm{CH}_{3} \mathrm{OH}\right) ;{ }^{1} \mathrm{H}$ NMR $\left(400 \mathrm{MHz}, \mathrm{CD}_{3} \mathrm{OD}\right) \delta(\mathrm{ppm}) 2.29(\mathrm{~s}, 3 \mathrm{H}), 3.14(\mathrm{dd}, J=2.9,15.8 \mathrm{~Hz}, 1 \mathrm{H})$, $3.45(\mathrm{dd}, J=6.2,15.8 \mathrm{~Hz}, 1 \mathrm{H}), 3.93\left(\mathrm{~d}, J_{A B}=17.8 \mathrm{~Hz}, 1 \mathrm{H}\right), 4.08\left(\mathrm{~d}, J_{A B}=17.8 \mathrm{~Hz}, 1 \mathrm{H}\right), 4.63$ $(\mathrm{dd}, J=2.9,6.2 \mathrm{~Hz}, 1 \mathrm{H}), 7.04-7.08(\mathrm{~m}, 1 \mathrm{H}), 7.15-7.22(\mathrm{~m}, 2 \mathrm{H}), 7.79(\mathrm{~d}, J=8.0 \mathrm{~Hz}, 1 \mathrm{H}) ;{ }^{13} \mathrm{C}$ 
NMR (100 MHz, CD $\left.{ }_{3} \mathrm{OD}\right) \delta(\mathrm{ppm}) 17.7,41.9,42.3,51.5,122.9,126.0,127.6,129.9,131.5$, 136.4, 149.4, 167.9, 171.5, 172.5; ESI-MS m/z 609 [2M-H]. Found C, 55.21; H, 4.99; N, 13.58 $\% ; \mathrm{C}_{14} \mathrm{H}_{15} \mathrm{~N}_{3} \mathrm{O}_{5}$ requires $\mathrm{C}, 55.08 ; \mathrm{H}, 4.95 ; \mathrm{N}, 13.76 \%$.

\section{(S)-3-(4-oxo-1-(o-tolylcarbamoyl)azetidine-2-carboxamido)propanoic acid (7)}

Following GP2 compound 28 (32 mg, $0.80 \mathrm{mmol})$ yielded compound 7 as a white solid (22 $\mathrm{mg}$, 88\%). Mp $161-163^{\circ} \mathrm{C}$; IR (film, $\left.\mathrm{cm}^{-1}\right) 3353,1781,1739,1708,1649 ;[\alpha]^{20}{ }_{\mathrm{D}}=-7(\mathrm{c}=1.10$, $\left.\mathrm{CH}_{3} \mathrm{OH}\right) ;{ }^{1} \mathrm{H} \mathrm{NMR}\left(400 \mathrm{MHz}, \mathrm{CD}_{3} \mathrm{OD}\right) \delta(\mathrm{ppm}) 2.29(\mathrm{~s}, 3 \mathrm{H}), 2.56(\mathrm{t}, J=6.6 \mathrm{~Hz}, 2 \mathrm{H}), 3.08(\mathrm{dd}$, $J=2.9,15.8 \mathrm{~Hz}, 1 \mathrm{H}), 3.39(\mathrm{dd}, J=6.1,15.8 \mathrm{~Hz}, 1 \mathrm{H}), 3.45-3.57(\mathrm{~m}, 2 \mathrm{H}), 4.52(\mathrm{dd}, J=2.9,6.1$ $\mathrm{Hz}, 1 \mathrm{H}), 7.04-7.07(\mathrm{~m}, 1 \mathrm{H}), 7.16-7.22(\mathrm{~m}, 2 \mathrm{H}), 7.79(\mathrm{~d}, J=8.0 \mathrm{~Hz}, 1 \mathrm{H}) ;{ }^{13} \mathrm{C}$ NMR $(100$ $\left.\mathrm{MHz}, \mathrm{CD}_{3} \mathrm{OD}\right) \delta(\mathrm{ppm}) 17.7,34.4,36.6,42.1,51.6,122.9,126.0,127.6,129.9,131.5,136.4$, 149.3, 168.0, 171.0, 175.1; ESI-MS m/z 318 [M-H]'. Found C, 56.83; H, 5.38; N, $13.02 \%$; $\mathrm{C}_{15} \mathrm{H}_{17} \mathrm{~N}_{3} \mathrm{O}_{5}$ requires $\mathrm{C}, 56.42 ; \mathrm{H}, 5.37 ; \mathrm{N}, 13.16 \%$.

\section{2-(4-oxoazetidin-2-yl)acetic acid (8)}

Following GP2 compound 13 (130 mg, 0.59 mmol) yielded compound 8 as a white solid (75 mg, 99\%). Mp $120-125^{\circ} \mathrm{C}$; IR (nujol, $\mathrm{cm}^{-1}$ ) 3230, 1752, 1695; ${ }^{1} \mathrm{H}$ NMR (400 MHz, $\left.\mathrm{CD}_{3} \mathrm{OD}\right) \delta$ (ppm) $2.61(\mathrm{dd}, J=7.7,16.8 \mathrm{~Hz}, 1 \mathrm{H}), 2.65(\mathrm{dd}, J=2.3,14.8 \mathrm{~Hz}, 1 \mathrm{H}), 2.69(\mathrm{dd}, J=5.8,16.8 \mathrm{~Hz}$, $1 \mathrm{H}), 3.10(\mathrm{dd}, J=4.9,14.8 \mathrm{~Hz}, 1 \mathrm{H}), 3.90-3.96(\mathrm{~m}, 1 \mathrm{H}) ;{ }^{13} \mathrm{C} \mathrm{NMR}\left(100 \mathrm{MHz}, \mathrm{CD}_{3} \mathrm{OD}\right) \delta(\mathrm{ppm})$ 40.5, 43.4, 45.3, 170.7, 174.6. Found $\mathrm{C}, 46.71 ; \mathrm{H}, 5.59 ; \mathrm{N}, 10.78 \% ; \mathrm{C}_{5} \mathrm{H}_{7} \mathrm{NO}_{3}$ requires $\mathrm{C}, 46.51$; H, 5.46; N, $10.85 \%$. 


\section{2-(4-oxo-(o-tolylcarbamoyl)azetidin-2-yl) acetic acid (9)}

Following GP2 compound 12 (88 mg, $0.25 \mathrm{mmol})$ yielded compound 9 as a white solid $(65 \mathrm{mg}$, 99\%). Mp $114-117^{\circ} \mathrm{C}$; IR (film, $\mathrm{cm}^{-1}$ ) 3344, 1766, 1708; ${ }^{1} \mathrm{H}$ NMR (400 MHz, $\left.\left(\mathrm{CD}_{3}\right)_{2} \mathrm{CO}\right) \delta$ (ppm) 2.27 (s, 3H), $2.90(\mathrm{dd}, J=9.1,16.7 \mathrm{~Hz}, 1 \mathrm{H}), 3.08(\mathrm{dd}, J=2.9,16.0 \mathrm{~Hz}, 1 \mathrm{H}), 3.26(\mathrm{dd}, J=$ 3.7, 16.7 Hz, 1H), $3.42(\mathrm{dd}, J=5.7,16.0 \mathrm{~Hz}, 1 \mathrm{H}), 4.42-4.46(\mathrm{~m}, 1 \mathrm{H}), 7.00-7.04(\mathrm{~m}, 1 \mathrm{H}), 7.17$ $-7.23(\mathrm{~m}, 2 \mathrm{H}), 7.99(\mathrm{~d}, J=8.1 \mathrm{~Hz}, 1 \mathrm{H}), 8.55(\mathrm{bs}, 1 \mathrm{H}) ;{ }^{13} \mathrm{C} \mathrm{NMR}\left(100 \mathrm{MHz},\left(\mathrm{CD}_{3}\right)_{2} \mathrm{CO}\right) \delta(\mathrm{ppm})$ 17.6, 36.6, 43.1, 48.4, 121.2, 124.7, 127.4, 127.7, 131.2, 136.9, 148.8, 168.4, 171.7; ESI-MS m/z $263[\mathrm{M}+\mathrm{H}]^{+}, 285[\mathrm{M}+\mathrm{Na}]^{+}, 547[2 \mathrm{M}+\mathrm{Na}]^{+}$. Found $\mathrm{C}, 59.24 ; \mathrm{H}, 5.56 ; \mathrm{N}, 10.44 \% ; \mathrm{C}_{13} \mathrm{H}_{14} \mathrm{~N}_{2} \mathrm{O}_{4}$ requires $\mathrm{C}, 59.54 ; \mathrm{H}, 5.38 ; \mathrm{N}, 10.68 \%$.

\section{Methyl 2-(4-oxo-1-(o-tolylcarbamoyl)azetidin-2-yl)acetate (10)}

Compound $29(77 \mathrm{mg}, 0.54 \mathrm{mmol})$ was treated with $\mathrm{K}_{2} \mathrm{CO}_{3}(112 \mathrm{mg}, 0.81 \mathrm{mmol})$ and commercial o-tolyl isocyanate $(80 \mu \mathrm{L}, 0.65 \mathrm{mmol})$ following GP1B. Chromatography $\left(\mathrm{CH}_{2} \mathrm{Cl}_{2} / \mathrm{Et}_{2} \mathrm{O}\right.$ 90:10) yielded 10 as a waxy yellow solid (110 mg, 74\%). IR (film, cm-1) 3335, 1766, 1736, 1710; ${ }^{1} \mathrm{H}$ NMR (400 MHz, $\left.\mathrm{CDCl}_{3}\right) \delta(\mathrm{ppm}) 2.30$ (s, 3H), $2.74(\mathrm{dd}, J=9.0,16.6 \mathrm{~Hz}$, 1H), $2.96(\mathrm{dd}, J=2.9,16.6 \mathrm{~Hz}, 1 \mathrm{H}), 3.35(\mathrm{dd}, J=4.6,12.6 \mathrm{~Hz}, 1 \mathrm{H}), 3.40(\mathrm{dd}, J=4.5,12.6 \mathrm{~Hz}$, 1H), $3.73(\mathrm{~s}, 3 \mathrm{H}), 4.43-4.49(\mathrm{~m}, 1 \mathrm{H}), 7.03-7.06(\mathrm{~m}, 1 \mathrm{H}), 7.18-7.23(\mathrm{~m}, 2 \mathrm{H}), 7.92(\mathrm{~d}, \mathrm{~J}=8.0$ $\mathrm{Hz}, 1 \mathrm{H}), 8.45$ (bs, 1H); ${ }^{13} \mathrm{C}$ NMR (100 MHz, $\left.\mathrm{CDCl}_{3}\right) \delta$ (ppm) 17.6, 36.7, 42.7, 47.4, 52.0, 121.0, $124.5,126.7,127.5,130.4,135.2,147.8,166.8,170.3 ;$ ESI-MS m/z $277[\mathrm{M}+\mathrm{H}]+$. Found $\mathrm{C}$, 61.12; $\mathrm{H}, 5.78 ; \mathrm{N}, 9.98 \% ; \mathrm{C}_{14} \mathrm{H}_{16} \mathrm{~N}_{2} \mathrm{O}_{4}$ requires $\mathrm{C}, 60.86 ; \mathrm{H}, 5.84 ; \mathrm{N}, 10.14 \%$. 


\section{Ethyl 2-(4-oxo-1-(o-tolylcarbamoyl)azetidin-2-yl)acetate (11)}

Compound 30 (65 mg, $0.41 \mathrm{mmol})$ was treated with $\mathrm{K}_{2} \mathrm{CO}_{3}(86 \mathrm{mg}, 0.62 \mathrm{mmol})$ and commercial $o$-tolyl isocyanate $(61 \mu \mathrm{L}, 0.49 \mathrm{mmol})$ following GP1B. Chromatography $\left(\mathrm{CH}_{2} \mathrm{Cl}_{2} / \mathrm{Et}_{2} \mathrm{O}\right.$ 80:20) yielded 11 as a white solid (110 mg, 81\%). Mp $91-93^{\circ} \mathrm{C}$; IR (film, $\mathrm{cm}^{-1}$ ) 3340, 1761, 1730, 1714; ${ }^{1} \mathrm{H}$ NMR (400 MHz, $\left.\mathrm{CDCl}_{3}\right) \delta(\mathrm{ppm}) 1.27(\mathrm{t}, J=7.1 \mathrm{~Hz}, 3 \mathrm{H}), 2.30$ (s, 3H), 2.74 (dd, $J=$ 9.0, $16.5 \mathrm{~Hz}, 1 \mathrm{H}), 2.96(\mathrm{dd}, J=2.8,16.5 \mathrm{~Hz}, 1 \mathrm{H}), 3.33(\mathrm{dd}, J=3.8,16.6 \mathrm{~Hz}, 1 \mathrm{H}), 3.38(\mathrm{dd}, J=$ $5.7,16.6 \mathrm{~Hz}, 1 \mathrm{H}), 4.18(\mathrm{q}, J=7.1 \mathrm{~Hz}, 2 \mathrm{H}), 4.43-4.48(\mathrm{~m}, 1 \mathrm{H}), 7.03-7.06(\mathrm{~m}, 1 \mathrm{H}), 7.17-7.23$ $(\mathrm{m}, 2 \mathrm{H}), 7.93(\mathrm{~d}, J=8.0 \mathrm{~Hz}, 1 \mathrm{H}), 8.45(\mathrm{bs}, 1 \mathrm{H}) ;{ }^{13} \mathrm{C} \mathrm{NMR}\left(100 \mathrm{MHz}, \mathrm{CDCl}_{3}\right) \delta(\mathrm{ppm}) 14.1$, $17.6,36.8,42.6,47.5,60.9,120.9,124.4,126.7,127.4,130.4,135.2,147.8,166.8,169.8$; ESIMS $m / z 291[\mathrm{M}+\mathrm{H}]^{+}, 603[2 \mathrm{M}+\mathrm{Na}]^{+}$. Found $\mathrm{C}, 62.13 ; \mathrm{H}, 6.27 ; \mathrm{N}, 9.41 \% ; \mathrm{C}_{15} \mathrm{H}_{18} \mathrm{~N}_{2} \mathrm{O}_{4}$ requires C, 62.06; H, 6.25; N, $9.65 \%$.

\section{Benzyl 2-(4-oxo-(o-tolylcarbamoyl)azetidin-2-yl) acetate (12)}

Compound 13 (75 mg, $0.34 \mathrm{mmol})$ was treated with $\mathrm{K}_{2} \mathrm{CO}_{3}(70 \mathrm{mg}, 0.54 \mathrm{mmol})$ and commercial $o$-tolyl isocyanate $(51 \mu \mathrm{L}, 0.41 \mathrm{mmol})$ following GP1B. Chromatography $\left(\mathrm{CH}_{2} \mathrm{Cl}_{2} / \mathrm{Et}_{2} \mathrm{O}\right.$ 90:10) yielded 12 as a white solid (110 mg, 74\%). Mp $74-76^{\circ} \mathrm{C}$; IR (film, $\mathrm{cm}^{-1}$ ) 3338, 1767, 1733, 1713; ${ }^{1} \mathrm{H}$ NMR $\left(400 \mathrm{MHz}, \mathrm{CDCl}_{3}\right) \delta(\mathrm{ppm}) 2.29(\mathrm{~s}, 3 \mathrm{H}), 2.81(\mathrm{dd}, J=8.8,16.5 \mathrm{~Hz}, 1 \mathrm{H}), 2.95$ $(\mathrm{dd}, J=2.8,16.5 \mathrm{~Hz}, 1 \mathrm{H}), 3.36(\mathrm{dd}, J=6.0,16.4 \mathrm{~Hz}, 1 \mathrm{H}), 3.37(\mathrm{dd}, J=4.8,16.4 \mathrm{~Hz}, 1 \mathrm{H}), 4.47-$ $4.49(\mathrm{~m}, 1 \mathrm{H}), 5.14\left(\mathrm{~d}, J_{\mathrm{AB}}=12.6 \mathrm{~Hz}, 1 \mathrm{H}\right), 5.18\left(\mathrm{~d}, J_{\mathrm{AB}}=12.6 \mathrm{~Hz}, 1 \mathrm{H}\right), 7.03-7.06(\mathrm{~m}, 1 \mathrm{H})$, $7.17-7.23(\mathrm{~m}, 2 \mathrm{H}), 7.32-7.37(\mathrm{~m}, 5 \mathrm{H}), 7.92(\mathrm{~d}, J=8.1 \mathrm{~Hz}, 1 \mathrm{H}), 8.42(\mathrm{bs}, 1 \mathrm{H}) ;{ }^{13} \mathrm{C}$ NMR $\left(100 \mathrm{MHz}, \mathrm{CDCl}_{3}\right) \delta(\mathrm{ppm})$ 17.7, 37.0, 42.6, 47.5, 66.8, 121.0, 124.4, 126.8, 127.5, 128.3, 128.4, 128.6, 130.4, 135.2, 135.3, 147.8, 166.7, 169.7; ESI-MS $m / z 353[\mathrm{M}+\mathrm{H}]^{+}, 375[\mathrm{M}+\mathrm{Na}]^{+}$, 
$727[2 \mathrm{M}+\mathrm{Na}]^{+}$. Found $\mathrm{C}, 68.43 ; \mathrm{H}, 5.88 ; \mathrm{N}, 7.80 \%, \mathrm{C}_{20} \mathrm{H}_{20} \mathrm{~N}_{2} \mathrm{O}_{4}$ requires $\mathrm{C}, 68.17 ; \mathrm{H}, 5.72 ; \mathrm{N}$, $7.95 \%$.

2-(1-(benzylcarbamoyl)-4-oxoazetidin-2-yl)acetic acid (14)

Following GP2 compound 33 (69 mg, $0.20 \mathrm{mmol}$ ) yielded compound 14 as a white solid (52 mg, 99\%). Mp $100-103^{\circ} \mathrm{C}$; IR (film, $\left.\mathrm{cm}^{-1}\right) 3356,1767,1734,1698 ;{ }^{1} \mathrm{H}$ NMR (400 MHz, $\left.\mathrm{CDCl}_{3}\right) \delta$ (ppm) $2.65(\mathrm{dd}, J=8.9,16.8 \mathrm{~Hz}, 1 \mathrm{H}), 2.82(\mathrm{dd}, J=2.3,16.3 \mathrm{~Hz}, 1 \mathrm{H}), 3.21-3.29(\mathrm{~m}, 2 \mathrm{H}), 4.31$ - $4.34(\mathrm{~m}, 1 \mathrm{H}), 4.37-4.47(\mathrm{~m}, 2 \mathrm{H}), 6.92(\mathrm{bt}, J=5.8 \mathrm{~Hz}, 1 \mathrm{H}), 7.23-7.32(\mathrm{~m}, 5 \mathrm{H}), 7.50$ (bs, $1 \mathrm{H}) ;{ }^{13} \mathrm{C} \mathrm{NMR}\left(100 \mathrm{MHz}, \mathrm{CDCl}_{3}\right) \delta(\mathrm{ppm}) 36.8,42.6,43.5,47.1,127.5,127.6,128.6,137.5$, 150.6, 166.4, 173.7; ESI-MS m/z 261 [M-H] $]^{-}$Found C, 59.41; H, 5.32; N, $10.59 \% ; \mathrm{C}_{13} \mathrm{H}_{14} \mathrm{~N}_{2} \mathrm{O}_{4}$ requires $\mathrm{C}, 59.54 ; \mathrm{H}, 5.38 ; \mathrm{N}, 10.68 \%$.

4-(2-(carboxymethyl)-4-oxoazetidine-1-carboxamidomethyl) benzenaminium trifluoroacetate (15)

Following GP3 compound 32 (14 mg, $0.37 \mathrm{mmol})$ and TFA (19.3 $\mu \mathrm{L}, 0.259 \mathrm{mmol}, 7$ equiv) yielded compound 15 (14 mg, 99\%) as a yellow oil. IR (film, cm-1) 3365, 1771, 1703, 1679; ${ }^{1} \mathrm{H}$ NMR (400 MHz, CD $\left.{ }_{3} \mathrm{OD}\right) \delta(\mathrm{ppm}) 2.75(\mathrm{dd}, J=8.7,16.6 \mathrm{~Hz}, 1 \mathrm{H}), 2.93(\mathrm{dd}, J=3.0,16.1 \mathrm{~Hz}$, $1 \mathrm{H}), 3.11(\mathrm{dd}, J=3.7,16.6 \mathrm{~Hz}, 1 \mathrm{H}), 3.27(\mathrm{dd}, J=5.8,16.1 \mathrm{~Hz}, 1 \mathrm{H}), 4.28-4.33(\mathrm{~m}, 1 \mathrm{H}), 4.44-$ $4.46(\mathrm{~m}, 2 \mathrm{H}), 7.29(\mathrm{~d}, J=8.4 \mathrm{~Hz}, 2 \mathrm{H}), 7.45(\mathrm{~d}, J=8.4 \mathrm{~Hz}, 2 \mathrm{H}) ;{ }^{13} \mathrm{C} \mathrm{NMR}\left(100 \mathrm{MHz}, \mathrm{CD}_{3} \mathrm{OD}\right) \delta$ (ppm) 37.3, 43.2, 43.5, 48.6, 123.9, 130.1, 131.4, 141.2, 152.6, 168.1, 173.5; ${ }^{19} \mathrm{~F}$ NMR (375 
MHz, CD3OD) $\delta(\mathrm{ppm})-77.0 ;$ ESI-MS m/z 278 [M-TFA+H]+. Found C, 46.32; H, 3.98; N, $10.56 \% ; \mathrm{C}_{15} \mathrm{H}_{16} \mathrm{~F}_{3} \mathrm{~N}_{3} \mathrm{O}_{6}$ requires $\mathrm{C}, 46.04 ; \mathrm{H}, 4.12 ; \mathrm{N}, 10.74 \%$.

\section{2-(4-oxo-(4-(3-o-tolylureidomethyl)phenylcarbamoyl)azetidin-2-yl) acetic acid (16)}

Following GP2 compound 37 (79 mg, $0.158 \mathrm{mmol}$ ) yielded compound 16 as a white solid (64 mg, 99\%). Mp $160-162^{\circ} \mathrm{C}$; IR (film, $\mathrm{cm}^{-1}$ ) 3319, 1774, 1707, 1629; ${ }^{1} \mathrm{H}$ NMR (400 MHz, $\left.\mathrm{CD}_{3} \mathrm{CN}\right) \delta(\mathrm{ppm}) 2,21(\mathrm{~s}, 3 \mathrm{H}), 2.76(\mathrm{dd}, J=6.0,16.5 \mathrm{~Hz}, 1 \mathrm{H}), 2.93(\mathrm{~d}, J=16.0 \mathrm{~Hz}, 1 \mathrm{H}), 3.13(\mathrm{~d}$, $J=16.5 \mathrm{~Hz}, 1 \mathrm{H}), 3.28(\mathrm{~d}, J=16.0 \mathrm{~Hz}, 1 \mathrm{H}), 4.31-4.36(\mathrm{~m}, 3 \mathrm{H}), 5.76(\mathrm{bs}, 1 \mathrm{H}), 6.68(\mathrm{bs}, 1 \mathrm{H})$, $6.95-6.99(\mathrm{~m}, 1 \mathrm{H}), 7.12-7.17(\mathrm{~m}, 2 \mathrm{H}), 7.29(\mathrm{~d}, J=8.9 \mathrm{~Hz}, 2 \mathrm{H}), 7.44(\mathrm{~d}, J=7.6 \mathrm{~Hz}, 2 \mathrm{H}), 7.68$

$(\mathrm{d}, J=7.8 \mathrm{~Hz}, 1 \mathrm{H}), 8.45$ (bs, $1 \mathrm{H}), 9.38(\mathrm{bs}, 1 \mathrm{H}) ;{ }^{13} \mathrm{C} \mathrm{NMR}\left(100 \mathrm{MHz}, \mathrm{CD}_{3} \mathrm{OD}\right) \delta(\mathrm{ppm}) 18.0$ $37.3,43.3,44.2,49.3,121.1,124.9,125.4,127.4,129.0,131.4,131.7,137.1,137.5,138.1$, 149.7, 158.8, 168.6, 173.5; ESI-MS $m / z 411[\mathrm{M}+\mathrm{H}]^{+}, 433[\mathrm{M}+\mathrm{Na}]^{+}, 821[2 \mathrm{M}+\mathrm{H}]^{+}$. Found $\mathrm{C}$, 61.33; $\mathrm{H}, 5.35 ; \mathrm{N}, 13.48 \% ; \mathrm{C}_{21} \mathrm{H}_{22} \mathrm{~N}_{4} \mathrm{O}_{5}$ requires $\mathrm{C}, 61.46 ; \mathrm{H}, 5.40 ; \mathrm{N}, 13.65 \%$.

\section{2-(2-(4-oxo-(o-tolylcarbamoyl)azetidin-2-yl) acetamido) acetic acid (17)}

Following GP2 compound $\mathbf{3 8}(85 \mathrm{mg}, 0.208 \mathrm{mmol}$ ) yielded compound $\mathbf{1 7}$ as a white solid (66 mg, 99\%). Mp $182-185^{\circ} \mathrm{C}$; IR (film, $\mathrm{cm}^{-1}$ ) 3300, 1764, 1720, 1649; ${ }^{1} \mathrm{H}$ NMR (400 MHz, $\left.\mathrm{CD}_{3} \mathrm{OD}\right) \delta(\mathrm{ppm}) 2.28(\mathrm{~s}, 3 \mathrm{H}), 2.74(\mathrm{dd}, J=8.5,14.8 \mathrm{~Hz}, 1 \mathrm{H}), 3.08-3.16(\mathrm{~m}, 2 \mathrm{H}), 3.29-3.37$ $(\mathrm{m}, 1 \mathrm{H}), 3.88\left(\mathrm{~d}, J_{\mathrm{AB}}=17.4 \mathrm{~Hz}, 1 \mathrm{H}\right), 3.94\left(\mathrm{~d}, J_{\mathrm{AB}}=17.4 \mathrm{~Hz}, 1 \mathrm{H}\right), 4.39-4.47(\mathrm{~m}, 1 \mathrm{H}), 7.03-$ $7.07(\mathrm{~m}, 1 \mathrm{H}), 7.16-7.22(\mathrm{~m}, 2 \mathrm{H}), 7.81(\mathrm{~d}, J=7.5 \mathrm{~Hz}, 1 \mathrm{H}), 8.63(\mathrm{bs}, 1 \mathrm{H}){ }^{13} \mathrm{C} \mathrm{NMR}(100 \mathrm{MHz}$, $\left.\mathrm{CD}_{3} \mathrm{OD}\right) \delta(\mathrm{ppm}) 17.8,38.8,41.8,43.1,54.8,122.9,125.8,127.6,129.8,131.5,136.6,150.0$, 
168.9, 172.3, 172.8; ESI-MS m/z 318 [M-H]', 637 [2M-H]. Found C, 56.13; H, 5.51; N, 12.98 $\% ; \mathrm{C}_{15} \mathrm{H}_{17} \mathrm{~N}_{3} \mathrm{O}_{5}$ requires $\mathrm{C}, 56.42 ; \mathrm{H}, 5.37 ; \mathrm{N}, 13.16 \%$.

4-(2-(1-carboxymethyl-amidomethyl)-4-oxoazetidine-1-carboxamidomethyl) benzenaminium 2,2,2-trifluoroacetate (18)

Following GP3 compound 41 (19 mg, $0.044 \mathrm{mmol})$ and TFA (23 $\mu \mathrm{L}, 0.306 \mathrm{mmol}, 7$ equiv) yielded compound 18 (18.5 mg, 95\%) as a yellow oil. IR (film, $\left.\mathrm{cm}^{-1}\right)$ 3356, 1793, 1782, 1736, 1712, 1698; ${ }^{1} \mathrm{H}$ NMR $\left(400 \mathrm{MHz}, \mathrm{CD}_{3} \mathrm{OD}\right) \delta(\mathrm{ppm}) 2.68(\mathrm{dd}, J=8.3,14.8 \mathrm{~Hz}, 1 \mathrm{H}), 3.01(\mathrm{dd}, J=$ $2.8,16.1 \mathrm{~Hz}, 1 \mathrm{H}), 3.07(\mathrm{dd}, J=4.0,14.8 \mathrm{~Hz}, 1 \mathrm{H}), 3.24(\mathrm{dd}, J=5.7,16.1 \mathrm{~Hz}, 1 \mathrm{H}), 3.85-3.94$ $(\mathrm{m}, 2 \mathrm{H}), 4.31-4.38(\mathrm{~m}, 1 \mathrm{H}), 4.43\left(\mathrm{~d}, J_{\mathrm{AB}}=15.8 \mathrm{~Hz}, 1 \mathrm{H}\right), 4.48\left(\mathrm{~d}, J_{\mathrm{AB}}=15.8 \mathrm{~Hz}, 1 \mathrm{H}\right), 7.33(\mathrm{~d}, J$ $=8.3 \mathrm{~Hz}, 2 \mathrm{H}), 7.47(\mathrm{~d}, J=8.3 \mathrm{~Hz}, 2 \mathrm{H}) ;{ }^{13} \mathrm{C} \mathrm{NMR}\left(100 \mathrm{MHz}, \mathrm{CD}_{3} \mathrm{OD}\right) \delta(\mathrm{ppm}) 30.7,38.9,42.9$, $43.5,49.3,123.8,130.1,131.8,141.0,152.6,168.1,172.3,172.8 ;{ }^{19} \mathrm{~F}$ NMR $\left(375 \mathrm{MHz}, \mathrm{CD}_{3} \mathrm{OD}\right)$ $\delta(\mathrm{ppm})-77.0 ;$ ESI-MS m/z $335[\mathrm{M}-\mathrm{TFA}+\mathrm{H}]^{+}$. Found C, 45.28; H, 4.51; N, $12.35 \%$; $\mathrm{C}_{17} \mathrm{H}_{19} \mathrm{~F}_{3} \mathrm{~N}_{4} \mathrm{O}_{7}$ requires $\mathrm{C}, 45.54 ; \mathrm{H}, 4.27 ; \mathrm{N}, 12.50 \%$.

3-(2-(4-oxo-(o-tolylcarbamoyl)azetidin-2-yl)acetamido) propanoic acid (19)

Following GP2 compound 39 (61 mg, $0.144 \mathrm{mmol}$ ) yielded compound 19 as a white solid (47 mg, 99\%). Mp $175-178^{\circ} \mathrm{C}$; IR (film, $\mathrm{cm}^{-1}$ ) 3300, 1769, 1700, 1638; ${ }^{1} \mathrm{H}$ NMR (400 MHz, $\left.\mathrm{CD}_{3} \mathrm{OD}\right) \delta(\mathrm{ppm}) 2.27(\mathrm{~s}, 3 \mathrm{H}), 2.47-2.56(\mathrm{~m}, 2 \mathrm{H}), 2.64(\mathrm{dd}, J=8.3,14.7 \mathrm{~Hz}, 1 \mathrm{H}), 3.00-3.08$ (m, 2H), $3.29-3.36(\mathrm{~m}, 1 \mathrm{H}), 3.40-3.48(\mathrm{~m}, 2 \mathrm{H}), 4.38-4.43(\mathrm{~m}, 1 \mathrm{H}), 7.03-7.06(\mathrm{~m}, 1 \mathrm{H}), 7.16$ $-7.22(\mathrm{~m}, 2 \mathrm{H}), 7.81(\mathrm{~d}, J=8.0 \mathrm{~Hz}, 1 \mathrm{H}), 8.19(\mathrm{bs}, 1 \mathrm{H}) ;{ }^{13} \mathrm{C} \mathrm{NMR}\left(100 \mathrm{MHz}, \mathrm{CD}_{3} \mathrm{OD}\right) \delta(\mathrm{ppm})$ 
$17.8,34.5,36.4,39.3,43.1,49.8,122.8,125.8,127.6,129.7,131.5,136.6,150.1,159.4,168.9$, 172.1; ESI-MS m/z $332[\mathrm{M}-\mathrm{H}]^{-}, 665$ [2M-H]'. Found C, 57.58; H, 5.80; N, $12.45 \%$; $\mathrm{C}_{16} \mathrm{H}_{19} \mathrm{~N}_{3} \mathrm{O}_{5}$ requires $\mathrm{C}, 57.65 ; \mathrm{H}, 5.75 ; \mathrm{N}, 12.61 \%$.

4-((2-(2-((2-carboxyethyl)amino)-2-oxoethyl)-4-oxoazetidine-1-carboxamido)methyl) benzenaminium 2,2,2-trifluoroacetate (20)

Following GP3 compound $43(19 \mathrm{mg}, 0.044 \mathrm{mmol})$ was treated with TFA (56 $\mu \mathrm{L}, 0.756 \mathrm{mmol}$, 18 equiv) yielding compound $\mathbf{2 0}\left(18 \mathrm{mg}, 93 \%\right.$ ) as a yellow oil. IR (film, $\left.\mathrm{cm}^{-1}\right)$ 3406, 1768, 1676, 1655, 1648; ${ }^{1} \mathrm{H}$ NMR (400 MHz, CD $\left.{ }_{3} \mathrm{OD}\right) \delta(\mathrm{ppm}) 2.49(\mathrm{t}, J=6.7 \mathrm{~Hz}, 2 \mathrm{H}), 2.59(\mathrm{dd}, J=8.1$, $14.6 \mathrm{~Hz}, 1 \mathrm{H}), 2.92-2.98(\mathrm{~m}, 2 \mathrm{H}), 3.24(\mathrm{dd}, J=5.7,16.1 \mathrm{~Hz}, 1 \mathrm{H}), 3.40(\mathrm{t}, J=6.7 \mathrm{~Hz}, 2 \mathrm{H}), 4.28$ $-4.33(\mathrm{~m}, 1 \mathrm{H}), 4.43\left(\mathrm{~d}, J_{\mathrm{AB}}=15.5 \mathrm{~Hz}, 1 \mathrm{H}\right), 4.48\left(\mathrm{~d}, J_{\mathrm{AB}}=15.5 \mathrm{~Hz}, 1 \mathrm{H}\right), 7.32(\mathrm{~d}, J=8.3 \mathrm{~Hz}$, 2H), $7.47(\mathrm{~d}, J=8.3 \mathrm{~Hz}, 2 \mathrm{H}) ;{ }^{13} \mathrm{C} \mathrm{NMR}\left(100 \mathrm{MHz}, \mathrm{CD}_{3} \mathrm{OD}\right) \delta(\mathrm{ppm}) 34.5,36.3,39.3,42.9$, $43.6,49.4,123.0,129.7,130.1,139.7,152.5,168.1,171.9,175.2 ;{ }^{19} \mathrm{~F}$ NMR (375 MHz, $\left.\mathrm{CD}_{3} \mathrm{OD}\right)$ $\delta(\mathrm{ppm})$-77.0; ESI-MS m/z $461[\mathrm{M}-\mathrm{H}]^{-}$. Found C, 46.89; H, 4.38; N, $12.00 \% ; \mathrm{C}_{18} \mathrm{H}_{21} \mathrm{~F}_{3} \mathrm{~N}_{4} \mathrm{O}_{7}$ requires $\mathrm{C}, 46.76 ; \mathrm{H}, 4.58 ; \mathrm{N}, 12.12 \%$.

(4-(2-(2-((2-carboxyethyl)amino)-2-oxoethyl)-4-oxoazetidine-1-carboxamido)phenyl) methanaminium 2,2,2-trifluoroacetate (21)

Following GP3 compound 46 (60 mg, $0.13 \mathrm{mmol})$ was treated with TFA (174 $\mu \mathrm{L}, 2.34 \mathrm{mmol}, 18$ equiv) yielding compound 21 (51 mg, 87\%) as a white solid. $\mathrm{Mp} 121-124^{\circ} \mathrm{C}$; IR (film, $\mathrm{cm}^{-1}$ ) 3060, 1781, 1753, 1699, 1685, 1655; ${ }^{1} \mathrm{H}$ NMR (400 MHz, $\left.\mathrm{CD}_{3} \mathrm{OD}\right) \delta(\mathrm{ppm}) 2.52(\mathrm{t}, J=6.7 \mathrm{~Hz}$, 
2H), $2.66(\mathrm{dd}, J=7.9,14.9 \mathrm{~Hz}, 1 \mathrm{H}), 2.98-3.04(\mathrm{~m}, 2 \mathrm{H}), 3.33-3.35(\mathrm{~m}, 1 \mathrm{H}), 3.43(\mathrm{t}, J=6.7$ $\mathrm{Hz}, 2 \mathrm{H}), 4.08(\mathrm{~s}, 2 \mathrm{H}), 4.39-4.42(\mathrm{~m}, 1 \mathrm{H}), 7.41(\mathrm{~d}, J=8.5 \mathrm{~Hz}, 2 \mathrm{H}), 7.59(\mathrm{~d}, J=8.5 \mathrm{~Hz}, 2 \mathrm{H})$, 8.88 (bs, 1H); ${ }^{13} \mathrm{C}$ NMR (100 MHz, $\left.\mathrm{CD}_{3} \mathrm{OD}\right) \delta$ (ppm) 34.6, 36.4, 39.3, 43.1, 43.9, 49.8, 121.3, $121.4,129.9,130.9,139.6,149.5,168.5,172.1,175.2 ;{ }^{19} \mathrm{~F}$ NMR $\left(375 \mathrm{MHz}, \mathrm{CD}_{3} \mathrm{OD}\right) \delta(\mathrm{ppm})-$ 77.0; ESI-MS m/z $461[\mathrm{M}-\mathrm{H}]^{-}$. Found $\mathrm{C}, 46.58 ; \mathrm{H}, 4.76 ; \mathrm{N}, 11.84 \% ; \mathrm{C}_{18} \mathrm{H}_{21} \mathrm{~F}_{3} \mathrm{~N}_{4} \mathrm{O}_{7}$ requires $\mathrm{C}$, 46.76; H, 4.58; N, $12.12 \%$.

(S)-Benzyl 1-(4-tert-butoxycarbonylaminobenzylcarbamoyl)-4-oxoazetidine-2-carboxylate (24)

Compound $22(35 \mathrm{mg}, 0.17 \mathrm{mmol})$ was treated with NaHMDSA (375 $\mu \mathrm{L}, 0.375 \mathrm{mmol})$ and isocyanate 23 (64 mg, $0.26 \mathrm{mmol}$ ) following GP1A. Flash chromatography $\left(\mathrm{CH}_{2} \mathrm{Cl}_{2} / \mathrm{Et}_{2} \mathrm{O}\right.$ 95:5) yielded 24 as a colorless oil (69 mg, 37\%). IR (film, $\mathrm{cm}^{-1}$ ) 3358, 1780, 1744, 1731, 1709; $[\alpha]^{20}{ }_{\mathrm{D}}$ $=-0.4\left(\mathrm{c}=0.93, \mathrm{CH}_{2} \mathrm{Cl}_{2}\right) ;{ }^{1} \mathrm{H} \mathrm{NMR}\left(400 \mathrm{MHz}, \mathrm{CDCl}_{3}\right) \delta(\mathrm{ppm}) 1.51(\mathrm{~s}, 9 \mathrm{H}), 3.01(\mathrm{dd}, J=2.8$, $15.6 \mathrm{~Hz}, 1 \mathrm{H}), 3.30(\mathrm{dd}, J=6.2,15.6 \mathrm{~Hz}, 1 \mathrm{H}), 4.38(\mathrm{dd}, J=6.0,14.8 \mathrm{~Hz}, 1 \mathrm{H}), 4.45(\mathrm{dd}, J=6.0$, $14.8 \mathrm{~Hz}, 1 \mathrm{H}), 4.52(\mathrm{dd}, J=2.8,6.2 \mathrm{~Hz}, 1 \mathrm{H}), 5.22\left(\mathrm{~d}, J_{A B}=12.2 \mathrm{~Hz}, 1 \mathrm{H}\right), 5.27\left(\mathrm{~d}, J_{A B}=12.2 \mathrm{~Hz}\right.$, 1H), $6.56(\mathrm{~s}, 1 \mathrm{H}), 6.67$ (bt, $J=6.0 \mathrm{~Hz}, 1 \mathrm{H}), 7.19-7.21(\mathrm{~m}, 2 \mathrm{H}), 7.27-7.39(\mathrm{~m}, 7 \mathrm{H}) ;{ }^{13} \mathrm{C}$ NMR (100 MHz, $\left.\mathrm{CDCl}_{3}\right) \delta(\mathrm{ppm}) 28.2,41.0,43.3,48.7,67.6,80.4,118.7,128.2,128.3,128.5$, 128.6, 129.9, 132.0, 134.7, 137.8, 149.3, 152.6, 164.6, 169.0; ESI-MS $m / z 471\left[\mathrm{M}+\mathrm{H}_{2} \mathrm{O}\right]^{+}, 476$ $[\mathrm{M}+\mathrm{Na}]^{+}$.

(S)-1-(4-tert-butoxycarbonylaminobenzylcarbamoyl)-4-oxoazetidine-2-carboxylic acid (25) 
Following GP2 compound 24 (51 mg, $0.11 \mathrm{mmol})$ yielded compound 25 as a waxy white solid (35 mg, 88\%). IR (film, $\left.\mathrm{cm}^{-1}\right) 3363,1770,1699,1694,1692 ;[\alpha]^{20}{ }_{\mathrm{D}}=-0.5\left(\mathrm{c}=0.64, \mathrm{CH}_{3} \mathrm{OH}\right)$; ${ }^{1} \mathrm{H}$ NMR (400 MHz, CD $\left.3 \mathrm{OD}\right) \delta(\mathrm{ppm}) 1.50(\mathrm{~s}, 9 \mathrm{H}), 2.90$ (dd, $\left.J=2.8,15.6 \mathrm{~Hz}, 1 \mathrm{H}\right), 3.27$ (dd, $J=$ 6.4, $15.6 \mathrm{~Hz}, 1 \mathrm{H}), 4.31-4.41(\mathrm{~m}, 3 \mathrm{H}), 7.22(\mathrm{~d}, J=8.4 \mathrm{~Hz}, 2 \mathrm{H}), 7.35(\mathrm{~d}, J=8.4 \mathrm{~Hz}, 2 \mathrm{H}) ;{ }^{13} \mathrm{C}$ NMR (100 MHz, CD $\left.{ }_{3} \mathrm{OD}\right) \delta(\mathrm{ppm}) 28.7,41.9,43.9,49.2,80.8,119.9,128.9,130.1,133.8$, 139.7, 150.7, 151.7, 155.2, 166.6; ESI-MS m/z 362 [M-H].

\section{(S)-Benzyl 4-oxo-(o-tolylcarbamoyl)azetidine-2-carboxylate (26)}

Compound 22 (103 mg, $0.5 \mathrm{mmol})$ was treated with $\mathrm{K}_{2} \mathrm{CO}_{3}(104 \mathrm{mg}, 0.75 \mathrm{mmol})$ and commercial $o$-tolyl isocyanate $(74 \mu \mathrm{L}, 0.6 \mathrm{mmol})$ following GP1B. Flash chromatography (Cyclohexane/AcOEt 70:30) yielded 26 as a light brown oil (126 mg, 75\%). IR (film, $\mathrm{cm}^{-1}$ ) $3348,1776,1751,1718 ;[\alpha]^{20}{ }_{\mathrm{D}}=-9\left(\mathrm{c}=1.15, \mathrm{CH}_{2} \mathrm{Cl}_{2}\right) ;{ }^{1} \mathrm{H}$ NMR $\left(400 \mathrm{MHz}, \mathrm{CDCl}_{3}\right) \delta(\mathrm{ppm})$ $2.30(\mathrm{~s}, 3 \mathrm{H}), 3.12(\mathrm{dd}, J=2.8,15.8 \mathrm{~Hz}, 1 \mathrm{H}), 3.42(\mathrm{dd}, J=6.2,15.8 \mathrm{~Hz}, 1 \mathrm{H}), 4.62(\mathrm{dd}, J=2.8$, $6.2 \mathrm{~Hz}, 1 \mathrm{H}), 5.25\left(\mathrm{~d}, J_{A B}=12.2 \mathrm{~Hz}, 1 \mathrm{H}\right), 5.30\left(\mathrm{~d}, J_{A B}=12.2 \mathrm{~Hz}, 1 \mathrm{H}\right), 7.04-7.08(\mathrm{~m}, 1 \mathrm{H}), 7.18-$ $7.21(\mathrm{~m}, 2 \mathrm{H}), 7.35-7.38(\mathrm{~m}, 5 \mathrm{H}), 7.93(\mathrm{~d}, J=8.1 \mathrm{~Hz}, 1 \mathrm{H}), 8.28(\mathrm{bs}, 1 \mathrm{H}) ;{ }^{13} \mathrm{C} \mathrm{NMR}(100 \mathrm{MHz}$, $\left.\mathrm{CDCl}_{3}\right) \delta(\mathrm{ppm}) 17.3,41.0,48.8,67.5,120.9,124.4,126.6,127.4,128.1,128.4,128.4,130.2$, 134.6, 134.9, 146.6, 165.1, 168.7; ESI-MS $m / z 339[\mathrm{M}+\mathrm{H}]^{+}, 361[\mathrm{M}+\mathrm{Na}]^{+}, 699[2 \mathrm{M}+\mathrm{Na}]^{+}$.

\section{Benzyl (S)-(4-oxo-1-(o-tolylcarbamoyl)azetidine-2-carbonyl)glycinate (27)}

Carboxylic acid 4 (40 mg, $0.16 \mathrm{mmol}, 1$ equiv) was dissolved in $\mathrm{CH}_{2} \mathrm{Cl}_{2}(1.6 \mathrm{~mL})$ under nitrogen and oxalyl chloride ( $21 \mu \mathrm{L}, 0.24 \mathrm{mmol}, 1.5$ equiv) was added dropwise. The mixture was stirred 
at room temperature for $1.5 \mathrm{~h}$ and glycine benzylester hydrochloride $(32 \mathrm{mg}, 0.16 \mathrm{mmol}, 1$ equiv) was then added, followed by the addition of TEA (112 $\mu \mathrm{L}, 0.8 \mathrm{mmol}, 5$ equiv) in a coldwater bath and DMAP (4 mg, $0.032 \mathrm{mmol}, 0.2$ equiv). The mixture was warmed to $\mathrm{rt}$ and left under stirring overnight. After complete consumption of the starting material $(16 \mathrm{~h})$ the mixture was quenched with a saturated solution of $\mathrm{NH}_{4} \mathrm{Cl}$ and extracted with $\mathrm{CH}_{2} \mathrm{Cl}_{2}(3 \times 10 \mathrm{~mL})$. The collected organic layers were dried on $\mathrm{Na}_{2} \mathrm{SO}_{4}$, filtered and evaporated in vacuum. Purification by column chromatography (cyclohexane/AcOEt 60:40) afforded compound $\mathbf{2 7}(32 \mathrm{mg}, 51 \%$ ) as a white waxy solid.

IR (film, $\left.\mathrm{cm}^{-1}\right) 3337,1774,1750,1719,1687 ;[\alpha]^{20}{ }_{\mathrm{D}}=-12\left(\mathrm{c}=1.00, \mathrm{CH}_{2} \mathrm{Cl}_{2}\right) ;{ }^{1} \mathrm{H}$ NMR $(400$ $\left.\mathrm{MHz}, \mathrm{CDCl}_{3}\right) \delta(\mathrm{ppm}) 2.30(\mathrm{~s}, 3 \mathrm{H}), 3.32(\mathrm{dd}, J=6.4,16.4 \mathrm{~Hz}, 1 \mathrm{H}), 3.53(\mathrm{dd}, J=3.2,16.4 \mathrm{~Hz}$, $1 \mathrm{H}), 4.07-4.18(\mathrm{~m}, 2 \mathrm{H}), 4.70(\mathrm{dd}, J=3.2,6.4 \mathrm{~Hz}, 1 \mathrm{H}), 5.16\left(\mathrm{~d}, J_{A B}=12.4 \mathrm{~Hz}, 1 \mathrm{H}\right), 5.20\left(\mathrm{~d}, J_{A B}\right.$ $=12.4 \mathrm{~Hz}, 1 \mathrm{H}), 7.06-7.10(\mathrm{~m}, 1 \mathrm{H}), 7.19-7.24(\mathrm{~m}, 2 \mathrm{H}), 7.31-7.35(\mathrm{~m}, 5 \mathrm{H}), 7.88(\mathrm{~d}, J=8.0$ $\mathrm{Hz}, 1 \mathrm{H}), 7.99$ (bt, $J=5.0 \mathrm{~Hz}, 1 \mathrm{H}), 8.48(\mathrm{bs}, 1 \mathrm{H}) ;{ }^{13} \mathrm{C} \mathrm{NMR}\left(100 \mathrm{MHz}, \mathrm{CDCl}_{3}\right) \delta(\mathrm{ppm}) 17.6$, $40.4,41.6,51.7,67.2,121.4,125.0,126.8,128.0,128.3,128.5,128.6,130.5,134.6,135.0,148.9$, 166.8, 167.9, 169.0; ESI-MS m/z $396[\mathrm{M}+\mathrm{H}]^{+}, 418[\mathrm{M}+\mathrm{Na}]^{+}$.

\section{Benzyl (S)-3-(4-oxo-1-(o-tolylcarbamoyl)azetidine-2-carboxamido)propanoate (28)}

Carboxylic acid 4 (40 mg, $0.16 \mathrm{mmol}, 1$ equiv) was dissolved in $\mathrm{CH}_{2} \mathrm{Cl}_{2}(1.6 \mathrm{~mL}$ ) under nitrogen and oxalyl chloride (16 $\mu \mathrm{L}, 0.19 \mathrm{mmol}, 1.2$ equiv) was added dropwise. The mixture was stirred at room temperature for $1.5 \mathrm{~h}$ and $\beta$-alanine benzylester $p$-toluenesulfonate salt $(56 \mathrm{mg}, 0.16$ mmol, 1 equiv) was then added, followed by the addition of TEA ( $90 \mu \mathrm{L}, 0.64 \mathrm{mmol}, 4$ equiv) in a cold-water bath and DMAP (4 mg, $0.032 \mathrm{mmol}, 0.2$ equiv). The mixture was warmed to $\mathrm{rt}$ and 
left under stirring overnight. After complete consumption of the starting material $(16 \mathrm{~h})$ the mixture was quenched with a saturated solution of $\mathrm{NH}_{4} \mathrm{Cl}$ and extracted with $\mathrm{CH}_{2} \mathrm{Cl}_{2}(3 \times 10 \mathrm{~mL})$. The collected organic layers were dried on $\mathrm{Na}_{2} \mathrm{SO}_{4}$, filtered and evaporated in vacuum. Purification by column chromatography (cyclohexane/AcOEt 60:40) afforded compound 28 (35 $\mathrm{mg}, 54 \%)$ as a white waxy solid. IR (film, $\left.\mathrm{cm}^{-1}\right) 3340,1774,1729,1686,1683 ;[\alpha]^{20}{ }_{\mathrm{D}}=-11(\mathrm{c}=$ 1.00, $\left.\mathrm{CH}_{2} \mathrm{Cl}_{2}\right) ;{ }^{1} \mathrm{H}$ NMR (400 MHz, $\left.\mathrm{CDCl}_{3}\right) \delta(\mathrm{ppm}) 2.30(\mathrm{~s}, 3 \mathrm{H}), 2.63(\mathrm{t}, J=6.3 \mathrm{~Hz}, 2 \mathrm{H}), 3.28$ $(\mathrm{dd}, J=6.3,16.3 \mathrm{~Hz}, 1 \mathrm{H}), 3.48(\mathrm{dd}, J=3.2,16.3 \mathrm{~Hz}, 1 \mathrm{H}), 3.54-3.67$ (m, 2H), 4.55 (dd, $J=3.2$, $6.3 \mathrm{~Hz}, 1 \mathrm{H}), 5.12(\mathrm{~s}, 2 \mathrm{H}), 7.05-7.09(\mathrm{~m}, 1 \mathrm{H}), 7.19-7.22(\mathrm{~m}, 2 \mathrm{H}), 7.30-7.35(\mathrm{~m}, 5 \mathrm{H}), 7.71$ (bs, $1 \mathrm{H}), 7.88(\mathrm{~d}, J=8.8 \mathrm{~Hz}, 1 \mathrm{H}), 8.46(\mathrm{bs}, 1 \mathrm{H}) ;{ }^{13} \mathrm{C} \mathrm{NMR}\left(100 \mathrm{MHz}, \mathrm{CDCl}_{3}\right) \delta(\mathrm{ppm})$ 17.6, $33.9,35.3,40.4,51.8,66.5,121.4,125.0,126.8,128.0,128.2,128.3,128.5,130.5,134.7,135.6$, 148.7, 166.9, 167.5, 171.6; ESI-MS $m / z 410[\mathrm{M}+\mathrm{H}]^{+}, 432[\mathrm{M}+\mathrm{Na}]^{+}$.

\section{Methyl 2-(4-oxoazetidin-2-yl)acetate (29)}

Zn powder (2.018 g, $31.04 \mathrm{mmol}, 7.2$ equiv) was suspended in THF (9.7 $\mathrm{mL})$ under nitrogen followed by TMSCl (196 $\mu \mathrm{L}, 1.552 \mathrm{mmol}, 0.1$ equiv) addition. After $30 \mathrm{~min}$ of stirring the temperature was raised to $30 \div 35{ }^{\circ} \mathrm{C}$ and a solution of methyl bromoacetate $(1.47 \mathrm{~mL}, 15.52$ mmol, 3.6 equiv) in THF (19.4 mL) was added dropwise in $30 \mathrm{~min}$. After $30 \mathrm{~min}$ of stirring the mixture was cooled to $\mathrm{rt}$ and decanted, providing a limpid grey supernatant that was added dropwise to a solution of commercially available 4-acetoxy-azetidin-2-one (500 mg, $3.88 \mathrm{mmol}$, 1 equiv) in anhydrous THF $(22 \mathrm{~mL})$ at $0^{\circ} \mathrm{C}$. The mixture was stirred at $\mathrm{rt}$ for $3 \mathrm{~h}$, quenched with ice and a saturated Seignette salt solution and extracted with AcOEt $(5 \times 50 \mathrm{~mL})$. The organic 
layers were dried on $\mathrm{Na}_{2} \mathrm{SO}_{4}$, filtered and concentrated in vacuum. Flash-chromatography (cyclohexane/AcOEt 70:30 to AcOEt 100\%) yielded ester 29 (332 mg, 60\%) as a yellow solid.

Mp $60-65^{\circ} \mathrm{C}$; IR (film, $\mathrm{cm}^{-1}$ ) 3390, 1760, 1730; ${ }^{1} \mathrm{H}$ NMR (400 MHz, $\left.\mathrm{CDCl}_{3}\right) \delta(\mathrm{ppm}) 2.63(\mathrm{dd}$, $J=8.6,16.7 \mathrm{~Hz}, 1 \mathrm{H}), 2.69-2.73(\mathrm{~m} 1 \mathrm{H}), 2.74(\mathrm{dd}, J=5.0,16.7 \mathrm{~Hz}, 1 \mathrm{H}), 3.20(\mathrm{ddd}, J=2.2$, 5.0, $15.2 \mathrm{~Hz}, 1 \mathrm{H}), 3.70(\mathrm{~s}, 3 \mathrm{H}), 3.96-4.02(\mathrm{~m}, 1 \mathrm{H}), 6.77$ (bs, $1 \mathrm{H}) ;{ }^{13} \mathrm{C} \mathrm{NMR}\left(100 \mathrm{MHz}, \mathrm{CDCl}_{3}\right)$ $\delta(\mathrm{ppm}) 39.2,43.0,44.6,52.0,169.0,171.0 ;$ ESI-MS $m / z 144[\mathrm{M}+\mathrm{H}]^{+}$.

\section{Ethyl 2-(4-oxoazetidin-2-yl)acetate (30)}

Following the procedure reported for $\mathbf{2 9}$, commercially available 4-acetoxy-azetidin-2-one (500 $\mathrm{mg}, 3.88 \mathrm{mmol}, 1$ equiv) was treated with ethyl bromoacetate $(1.72 \mathrm{~mL}, 15.52 \mathrm{mmol}, 3.6$ equiv). Purification by column chromatography $\left(\mathrm{CH}_{2} \mathrm{Cl}_{2} /\right.$ acetone 80:20) yielded compound 30 (390 mg, $64 \%$ ) as a waxy yellow solid. IR (film, $\mathrm{cm}^{-1}$ ) $3224,1731,1725 ;{ }^{1} \mathrm{H}$ NMR $\left(400 \mathrm{MHz}, \mathrm{CDCl}_{3}\right) \delta$ (ppm) $1.27(\mathrm{t}, J=7.2 \mathrm{~Hz}, 3 \mathrm{H}), 2.58(\mathrm{dd}, J=9.0,16.6 \mathrm{~Hz}, 1 \mathrm{H}), 2.66(\mathrm{dd}, J=1.3,14.9 \mathrm{~Hz}, 1 \mathrm{H})$, $2.73(\mathrm{dd}, J=4.6,16.6 \mathrm{~Hz}, 1 \mathrm{H}), 3.16(\mathrm{ddd}, J=2.2,4.8,14.9 \mathrm{~Hz}, 1 \mathrm{H}), 3.92-3.95(\mathrm{~m}, 1 \mathrm{H}), 4.17$ (q, $J=7.1 \mathrm{~Hz}, 2 \mathrm{H}), 6.14(\mathrm{bs}, 1 \mathrm{H}) ;{ }^{13} \mathrm{C} \mathrm{NMR}\left(100 \mathrm{MHz}, \mathrm{CDCl}_{3}\right) \delta(\mathrm{ppm}) 14.2,39.9,43.4,43.8$, 61.0, 167.0, 170.9; ESI-MS $m / z 158[\mathrm{M}+\mathrm{H}]^{+}, 180[\mathrm{M}+\mathrm{Na}]^{+}$.

\section{Benzyl 2-(1-(4-tert-butoxycarbonylaminobenzylcarbamoyl)-4-oxoazetidin-2-yl acetate (31)}

Compound 13 (57 mg, $0.26 \mathrm{mmol}$ ) was treated with NaHMDSA (325 $\mu \mathrm{L}, 0.325 \mathrm{mmol})$ and isocyanate 23 (97 mg, $0.39 \mathrm{mmol})$ following GP1A. Chromatography $\left(\mathrm{CH}_{2} \mathrm{Cl}_{2} / \mathrm{Et}_{2} \mathrm{O}\right.$ 95:5) yielded 31 as a colorless oil (75 mg, 62\%). IR (film, $\mathrm{cm}^{-1}$ ) 3365, 1769, 1730, 1703, 1697; ${ }^{1} \mathrm{H}$ 
NMR (400 MHz, $\left.\mathrm{CDCl}_{3}\right) \delta(\mathrm{ppm}) 1.51(\mathrm{~s}, 9 \mathrm{H}), 2.71(\mathrm{dd}, J=9.0,16.5 \mathrm{~Hz}, 1 \mathrm{H}), 2.84(\mathrm{dd}, J=2.9$, $16.2 \mathrm{~Hz}, 1 \mathrm{H}), 3.26(\mathrm{dd}, J=5.6,16.2 \mathrm{~Hz}, 1 \mathrm{H}), 3.34(\mathrm{dd}, J=4.0,16.5 \mathrm{~Hz}, 1 \mathrm{H}), 4.31-4.43(\mathrm{~m}$, $3 \mathrm{H}), 5.12\left(\mathrm{~d}, J_{\mathrm{AB}}=12.2 \mathrm{~Hz}, 1 \mathrm{H}\right), 5.16\left(\mathrm{~d}, J_{\mathrm{AB}}=12.2 \mathrm{~Hz}, 1 \mathrm{H}\right), 6.46(\mathrm{bs}, 1 \mathrm{H}), 6.77(\mathrm{bt}, J=5.7 \mathrm{~Hz})$ $7.20-7.22(\mathrm{~m}, 2 \mathrm{H}), 7.30-7.39(\mathrm{~m}, 7 \mathrm{H}) ;{ }^{13} \mathrm{C} \mathrm{NMR}\left(100 \mathrm{MHz}, \mathrm{CDCl}_{3}\right) \delta(\mathrm{ppm}) 28.2,37.0,42.5$, $43.0,47.1,66.6,80.5,118.7,128.2,128.3,128.5,132.2,135.3,137.8,150.2,152.6,166.1$, 169.7; ESI-MS m/z $468[\mathrm{M}+\mathrm{H}]^{+}, 485\left[\mathrm{M}+\mathrm{H}_{2} \mathrm{O}\right]^{+}, 490[\mathrm{M}+\mathrm{Na}]^{+}, 506[\mathrm{M}+\mathrm{K}]^{+}$.

\section{2-(1-(4-tert-butoxycarbonylaminobenzylcarbamoyl)-4-oxoazetidin-2-yl acetic acid (32)}

Following GP2 compound 31 (39 mg, $0.80 \mathrm{mmol}$ ) yielded compound 32 as a white solid (30 mg, 99\%). Mp $78-81^{\circ} \mathrm{C}$; IR (film, $\mathrm{cm}^{-1}$ ) 3355, 1769, 1731, 1707, 1695; ${ }^{1} \mathrm{H}$ NMR (400 MHz, $\left.\mathrm{CD}_{3} \mathrm{OD}\right) \delta(\mathrm{ppm}) 1.51(\mathrm{~s}, 9 \mathrm{H}), 2.73(\mathrm{dd}, J=8.9,16.5 \mathrm{~Hz}, 1 \mathrm{H}), 2.91(\mathrm{dd}, J=2.6,16.0 \mathrm{~Hz}, 1 \mathrm{H})$, $3.13(\mathrm{dd}, J=2.4,16.5 \mathrm{~Hz}, 1 \mathrm{H}), 3.28(\mathrm{dd}, J=5.6,16.0 \mathrm{~Hz}, 1 \mathrm{H}), 4.28-4.31(\mathrm{~m}, 1 \mathrm{H}), 4.34-4.36$ $(\mathrm{m}, 2 \mathrm{H}), 7.21(\mathrm{~d}, J=8.4 \mathrm{~Hz} ; 2 \mathrm{H}), 7.35(\mathrm{~d}, J=8.3 \mathrm{~Hz} ; 2 \mathrm{H}) ;{ }^{13} \mathrm{C}$ NMR $\left(100 \mathrm{MHz}, \mathrm{CD}_{3} \mathrm{OD}\right) \delta$ (ppm) $28.7,37.3,43.2,43.7,43.8,80.8,119.9,128.9,133.9,139.7,152.4,155.2,168.1,173.5$; ESI-MS m/z 376 [M-H]'.

\section{Benzyl 2-(1-(benzylcarbamoyl)-4-oxoazetidin-2-yl)acetate (33)}

Compound 13 (80 mg, $0.37 \mathrm{mmol}$ ) was treated with $\mathrm{K}_{2} \mathrm{CO}_{3}(77 \mathrm{mg}, 0.56 \mathrm{mmol})$ and commercial benzyl isocyanate $(54 \mu \mathrm{L}, 0.44 \mathrm{mmol})$ following GP1B. Chromatography $\left(\mathrm{CH}_{2} \mathrm{Cl}_{2} / \mathrm{Et}_{2} \mathrm{O}\right.$ 90:10) yielded 33 as a light yellow oil (96 mg, 74\%). IR (film, $\mathrm{cm}^{-1}$ ) 3367, 1767, 1732, 1694; ${ }^{1} \mathrm{H}$ NMR $\left(400 \mathrm{MHz}, \mathrm{CDCl}_{3}\right) \delta(\mathrm{ppm}) 2.69(\mathrm{dd}, J=9.0,16.5 \mathrm{~Hz}, 1 \mathrm{H}), 2.81(\mathrm{dd}, J=2.9,16.2 \mathrm{~Hz}, 1 \mathrm{H}), 3.22$ 
$(\mathrm{dd}, J=5.6,16.2 \mathrm{~Hz}, 1 \mathrm{H}), 3.30(\mathrm{dd}, J=4.0,16.5 \mathrm{~Hz}, 1 \mathrm{H}), 4.31-4.36(\mathrm{~m}, 1 \mathrm{H}), 4.37-4.46(\mathrm{~m}$, $2 \mathrm{H}), 5.09\left(\mathrm{~d}, J_{\mathrm{AB}}=12.3 \mathrm{~Hz}, 1 \mathrm{H}\right), 5.13\left(\mathrm{~d}, J_{\mathrm{AB}}=12.3 \mathrm{~Hz}, 1 \mathrm{H}\right), 6.82(\mathrm{bt}, J=5.6 \mathrm{~Hz}, 1 \mathrm{H}), 7.22-$

$7.36(\mathrm{~m}, 10 \mathrm{H}) ;{ }^{13} \mathrm{C}$ NMR $\left(100 \mathrm{MHz}, \mathrm{CDCl}_{3}\right) \delta(\mathrm{ppm}) 37.0,42.4,43.4,47.0,66.6,127.4,127.5$, $128.2,128.3,128.5,128.6,135.3,137.7,150.3,166.1,169.6$; ESI-MS $m / z 353[\mathrm{M}+\mathrm{H}]^{+}$.

4-(2-(2-(benzyloxy)-2-oxoethyl)-4-oxoazetidine-carboxamido)phenyl methanaminium 2,2,2trifluoroacetate (36)

Following GP3 compound 35 (133 mg, $0.284 \mathrm{mmol}$ ) was treated with TFA (322 $\mu \mathrm{L}, 4.32 \mathrm{mmol}$, 15.2 equiv) yielding compound 36 (136 mg, 99\%) as a waxy white solid. IR (film, $\mathrm{cm}^{-1}$ ) 3336, 1771, 1704, 1680; ${ }^{1} \mathrm{H}$ NMR (400 MHz, $\left.\mathrm{CDCl}_{3}\right) \delta(\mathrm{ppm}) 2.81(\mathrm{dd}, J=8.6,16.5 \mathrm{~Hz}, 1 \mathrm{H}), 2.96$ $(\mathrm{dd}, J=2.6,16.4 \mathrm{~Hz}, 1 \mathrm{H}), 3.30-3.38(\mathrm{~m}, 2 \mathrm{H}), 4.25(\mathrm{bs}, 2 \mathrm{H}), 4.44-4.50(\mathrm{~m}, 1 \mathrm{H}), 5.16(\mathrm{~s}, 2 \mathrm{H})$, $7.21-7.23(\mathrm{~m}, 2 \mathrm{H}), 7.33-7.35(\mathrm{~m}, 5 \mathrm{H}), 7.39-7.41(\mathrm{~m}, 2 \mathrm{H}), 8.45(\mathrm{bs}, 1 \mathrm{H}), 8.77(\mathrm{bs}, 3 \mathrm{H}) ;{ }^{13} \mathrm{C}$ NMR (100 MHz, $\left.\mathrm{CDCl}_{3}\right) \delta(\mathrm{ppm}) 36.7,42.5,43.0,47.6,66.8,120.4,127.9,128.2,128.4,128.5$, $129.8,135.2,137.3,147.9,166.8,169.9 ;$ ESI-MS $m / z \quad 351 \quad\left[\mathrm{M}-\mathrm{TFA}-\mathrm{NH}_{3}+\mathrm{H}\right]^{+}, 735$ [2M$2 \mathrm{TFA}+\mathrm{H}]^{+}$.

\section{Benzyl 2-(4-oxo-(4-(3-o-tolylureidomethyl)phenylcarbamoyl)azetidin-2-yl) acetate (37)}

To a solution of 36 (136 mg, $0.28 \mathrm{mmol}, 1$ equiv) in THF (1.6 mL) under nitrogen was added dropwise TEA (43 $\mu \mathrm{L}, 0.31 \mathrm{mmol}, 1.1$ equiv) and left under stirring. After $30 \mathrm{~min}$ the mixture was cooled to $0^{\circ} \mathrm{C}$ and a solution of $o$-tolyl-isocyanate $(38 \mu \mathrm{L}, 0.31 \mathrm{mmol}, 1.1$ equiv) in $\mathrm{THF}$ $(0.8 \mathrm{~mL})$ was added. When TLC indicated the complete consumption of the starting material (1.5 
h), the mixture was concentrated under vacuum and the resulting crude was purified by flashchromatography $\left(\mathrm{CH}_{2} \mathrm{Cl}_{2} / \mathrm{AcOEt}, 90: 10\right.$ to $\left.70: 30\right)$ to afford 37 as a white solid (79 $\left.\mathrm{mg}, 56 \%\right)$. Mp $184-187^{\circ} \mathrm{C}$; IR (film, $\mathrm{cm}^{-1}$ ) 3319, 1771 1712; ${ }^{1} \mathrm{H}$ NMR (400 MHz, $\left.\mathrm{CDCl}_{3}\right) \delta(\mathrm{ppm}) 2.25(\mathrm{~s}$, $3 \mathrm{H}), 2.79(\mathrm{dd}, J=8.8,16.5 \mathrm{~Hz}, 1 \mathrm{H}), 2.94(\mathrm{dd}, J=2.6,16.3 \mathrm{~Hz}, 1 \mathrm{H}), 3.32-3.37(\mathrm{~m}, 2 \mathrm{H}), 4.40$ (bs, 2H), $4.42-4.47(\mathrm{~m}, 1 \mathrm{H}), 5.15(\mathrm{~s}, 2 \mathrm{H}), 6.21(\mathrm{bs}, 1 \mathrm{H}), 7.13-7.41(\mathrm{~m}, 13 \mathrm{H}), 8.41(\mathrm{bs}, 1 \mathrm{H})$;

${ }^{13} \mathrm{C}$ NMR $\left(100 \mathrm{MHz}, \mathrm{CDCl}_{3}\right) \delta(\mathrm{ppm})$ 17.8, 36.8, 42.7, 44.0, 47.5, 66.8, 119.9, 125.7, 126.3, $127.2,128.2,128.3,128.4,128.5,128.6,131.1,132.2,134.9,135.3,136.1,156.6,166.6,169.6$, 174.2; ESI-MS $m / z 501[\mathrm{M}+\mathrm{H}]^{+}, 523[\mathrm{M}+\mathrm{Na}]^{+}, 1001[2 \mathrm{M}+\mathrm{H}]^{+}$.

\section{Benzyl 2-(2-(4-oxo-(o-tolylcarbamoyl)azetidin-2-yl) acetamido) acetate (38)}

Carboxylic acid 9 (98 mg, $0.374 \mathrm{mmol}, 1$ equiv) was dissolved in $\mathrm{CH}_{2} \mathrm{Cl}_{2}$ (5.4 mL) under nitrogen. 1-Ethyl-3-(3-dimethylaminopropyl) carbodiimide (EDC) (72 mg, $0.374 \mathrm{mmol}, 1$ equiv) was then added at $0^{\circ} \mathrm{C}$. It was followed by the dropwise addition of a previously prepared solution of glycine benzyl ester $p$-toluenesulfonate salt (189 mg, $561 \mu \mathrm{mol}, 1.5$ equiv) and TEA (84 $\mu \mathrm{L}, 0.598$ mmol, 1.6 equiv) in $\mathrm{CH}_{2} \mathrm{Cl}_{2}(4.7 \mathrm{~mL}$ ). After addition of DMAP (46 mg, 0.374 mmol, 1 equiv), the solution was warmed to rt and left under stirring overnight. After complete consumption of the starting material $(16 \mathrm{~h})$ the mixture was quenched with $\mathrm{H}_{2} \mathrm{O}$ and extracted with $\mathrm{CH}_{2} \mathrm{Cl}_{2}(3 \times 10 \mathrm{~mL})$. The collected organic layers were dried on $\mathrm{Na}_{2} \mathrm{SO}_{4}$ and filtered. The organic layer was concentrated in vacuum and purified by flash-chromatography $\left(\mathrm{CH}_{2} \mathrm{Cl}_{2} / \mathrm{CH}_{3} \mathrm{CN}\right.$ 95:5 to 80:20) yielding compound $\mathbf{3 8}(85 \mathrm{mg}, 56 \%)$ as a light yellow solid. $\mathrm{Mp}$ $174-176^{\circ} \mathrm{C}$; IR (film, $\mathrm{cm}^{-1}$ ) $3321,1767,1723,1708,1645 ;{ }^{1} \mathrm{H}$ NMR $\left(400 \mathrm{MHz}, \mathrm{CDCl}_{3}\right) \delta$ (ppm) $2.30(\mathrm{~s}, 3 \mathrm{H}), 2.78(\mathrm{dd}, J=7.9,14.9 \mathrm{~Hz}, 1 \mathrm{H}), 3.14-3.21(\mathrm{~m}, 2 \mathrm{H}), 3.34(\mathrm{dd}, J=5.4,16.4$ 
Hz, 1H), $4.02(\mathrm{dd}, J=4.8,18.4 \mathrm{~Hz}, 1 \mathrm{H}), 4.11(\mathrm{dd}, J=5.4,18.4 \mathrm{~Hz}, 1 \mathrm{H}), 4.43-4.48(\mathrm{~m}, 1 \mathrm{H})$, $5.16(\mathrm{~s}, 2 \mathrm{H}), 6.43(\mathrm{bt}, J=5.8 \mathrm{~Hz}, 1 \mathrm{H}), 7.04-7.07(\mathrm{~m}, 1 \mathrm{H}), 7.18-7.23(\mathrm{~m}, 2 \mathrm{H}), 7.32-7.39(\mathrm{~m}$, 5H), 7.89 (d, $J=7.9 \mathrm{~Hz}, 1 \mathrm{H}), 8.51(\mathrm{bs}, 1 \mathrm{H}) ;{ }^{13} \mathrm{C} \mathrm{NMR}\left(100 \mathrm{MHz}, \mathrm{CDCl}_{3}\right) \delta(\mathrm{ppm}) 17.7,38.2$, $41.3,42.6,48.4,67.2,121.2,124.6,126.7,127.8,128.4,128.5,128.6,130.5,135.0,135.1,148.5$, 167.2, 169.2, 169.4; ESI-MS $m / z 410[\mathrm{M}+\mathrm{H}]^{+}, 432[\mathrm{M}+\mathrm{Na}]^{+}$.

\section{Benzyl 3-(2-(4-oxo-(o-tolylcarbamoyl)azetidin-2-yl)acetamido) propanoate (39)}

Carboxylic acid 9 (63 mg, $0.240 \mathrm{mmol}, 1$ equiv) was dissolved in $\mathrm{CH}_{2} \mathrm{Cl}_{2}(3.47 \mathrm{~mL})$ under nitrogen. EDC (46 mg, $0.240 \mathrm{mmol}, 1$ equiv) was then added at $0^{\circ} \mathrm{C}$. It was followed by the dropwise addition of a previously prepared solution of $\beta$-alanine benzylester $p$-toluenesulfonate salt (127 mg, $0.360 \mathrm{mmol}, 1.5$ equiv) and TEA (54 $\mu \mathrm{L}, 0.384 \mathrm{mmol}, 1.6$ equiv) in $\mathrm{CH}_{2} \mathrm{Cl}_{2}(3$ $\mathrm{mL}$ ). After addition of DMAP (29 $\mathrm{mg}, 0.240 \mathrm{mmol}, 1$ equiv), the solution was warmed to $\mathrm{rt}$ and left under stirring overnight. After complete consumption of the starting material $(16 \mathrm{~h})$ the mixture was quenched with $\mathrm{H}_{2} \mathrm{O}$ and extracted with $\mathrm{CH}_{2} \mathrm{Cl}_{2}(3 \times 10 \mathrm{~mL})$. The collected organic layers were dried on $\mathrm{Na}_{2} \mathrm{SO}_{4}$ and filtered. The organic layer was concentrated in vacuum and purified by flash-chromatography $\left(\mathrm{CH}_{2} \mathrm{Cl}_{2} / \mathrm{AcOEt} 80: 20\right.$ to $\left.70: 30\right)$ yielding compound 39 (61 $\mathrm{mg}, 60 \%$ ) as a white waxy solid.

IR (film, $\left.\mathrm{cm}^{-1}\right) 3334,1765,1732,1712,1656 ;{ }^{1} \mathrm{H}$ NMR (400 MHz, $\left.\mathrm{CDCl}_{3}\right) \delta(\mathrm{ppm}) 2.29(\mathrm{~s}, 3 \mathrm{H})$, $2.51-2.64(\mathrm{~m}, 3 \mathrm{H}), 3.07(\mathrm{dd}, J=3.8,15.1 \mathrm{~Hz}, 1 \mathrm{H}), 3.12(\mathrm{dd}, J=3.0,16.4 \mathrm{~Hz}, 1 \mathrm{H}), 3.32(\mathrm{dd}, J$ $=5.6,16.4 \mathrm{~Hz}, 1 \mathrm{H}), 3.48-3.57(\mathrm{~m}, 2 \mathrm{H}), 4.36-4.41(\mathrm{~m}, 1 \mathrm{H}), 5.06\left(\mathrm{~d}, J_{\mathrm{AB}}=12.4 \mathrm{~Hz}, 1 \mathrm{H}\right), 5.10$ $\left(\mathrm{d}, J_{\mathrm{AB}}=12.4 \mathrm{~Hz}, 1 \mathrm{H}\right), 6.44(\mathrm{bs}, 1 \mathrm{H}) 7.02-7.06(\mathrm{~m}, 1 \mathrm{H}), 7.17-7.22(\mathrm{~m}, 2 \mathrm{H}), 7.31-7.39(\mathrm{~m}$, 5H), $7.92(\mathrm{~d}, J=7.9 \mathrm{~Hz}, 1 \mathrm{H}), 8.50(\mathrm{bs}, 1 \mathrm{H}) ;{ }^{13} \mathrm{C} \mathrm{NMR}\left(100 \mathrm{MHz}, \mathrm{CDCl}_{3}\right) \delta(\mathrm{ppm}) 17.6,33.8$, 
$34.8,38.4,42.6,48.3,66.4,120.9,124.4,126.7,127.5,128.1,128.3,128.5,130.4,135.1,135.5$, 148.2, 167.2, 168.8, 172.0; ESI-MS $m / z 424[\mathrm{M}+\mathrm{H}]^{+}, 446[\mathrm{M}+\mathrm{Na}]^{+}$.

\section{Benzyl 2-(2-(4-tert-butoxycarbonylaminobenzylcarbamoyl)-4-oxoazetidin-2-yl acetamido) acetate (40)}

Carboxylic acid $32\left(27 \mathrm{mg}, 0.72 \mathrm{mmol}, 1\right.$ equiv) was dissolved in a mixture of $\mathrm{CH}_{2} \mathrm{Cl}_{2}(0.85 \mathrm{~mL})$ and $\mathrm{CH}_{3} \mathrm{CN}(0.17 \mathrm{~mL})$ under nitrogen. Dicyclohexylcarbodiimide (DCC) (16 mg, $0.79 \mathrm{mmol}$, 1.1 equiv) was then added at $0^{\circ} \mathrm{C}$. It was followed by the dropwise addition of a previously prepared solution of glycine benzylester $p$-toluenesulfonate salt (38 mg, $0.108 \mathrm{mmol}, 1.5$ equiv) and TEA (16 $\mu \mathrm{L}, 0.115 \mathrm{mmol}, 1.6$ equiv) in $\mathrm{CH}_{2} \mathrm{Cl}_{2}(0.9 \mathrm{~mL})$. After addition of catalytic DMAP ( $2 \mathrm{mg}, 0.014 \mathrm{mmol}, 0.2$ equiv), the solution was warmed to $\mathrm{rt}$ and left under stirring overnight. After complete consumption of the starting material $(16 \mathrm{~h})$ the mixture was quenched with $\mathrm{H}_{2} \mathrm{O}$ and extracted with $\mathrm{CH}_{2} \mathrm{Cl}_{2}(3 \times 10 \mathrm{~mL})$. The collected organic layers were dried on $\mathrm{Na}_{2} \mathrm{SO}_{4}$ and filtered. The crude was suspended in AcOEt and the solid residual dicyclohexylurea was eliminated by filtration. The organic layer was concentrated in vacuum and purified by flashchromatography $\left(\mathrm{CH}_{2} \mathrm{Cl}_{2} / \mathrm{CH}_{3} \mathrm{CN}\right.$ 95:5 to 80:20) yielding compound 40 (27 $\left.\mathrm{mg}, 72 \%\right)$ as a light yellow solid. Mp $64-66^{\circ} \mathrm{C}$; IR (film, $\mathrm{cm}^{-1}$ ) 3355, 1766, 1724, 1707, 1691, 1671; ${ }^{1} \mathrm{H}$ NMR (400 $\left.\mathrm{MHz}, \mathrm{CDCl}_{3}\right) \delta(\mathrm{ppm}) 1.50(\mathrm{~s}, 9 \mathrm{H}), 2.69(\mathrm{dd}, J=8.0,15.0 \mathrm{~Hz}, 1 \mathrm{H}), 3.05(\mathrm{dd}, J=3.0,16.4 \mathrm{~Hz}$, $1 \mathrm{H}), 3.10(\mathrm{dd}, J=3.8,15.0 \mathrm{~Hz}, 1 \mathrm{H}), 3.22(\mathrm{dd}, J=5.6,16.4 \mathrm{~Hz}, 1 \mathrm{H}), 3.99\left(\mathrm{dd}, J_{\mathrm{AB}}=5.4,18.2\right.$ $\mathrm{Hz}, 1 \mathrm{H}), 4.05\left(\mathrm{dd}, J_{\mathrm{AB}}=5.5,18.2 \mathrm{~Hz} ; 1 \mathrm{H}\right), 4.30-4.41(\mathrm{~m}, 3 \mathrm{H}), 5.16(\mathrm{~s}, 2 \mathrm{H}), 6.54(\mathrm{bs}, 1 \mathrm{H}), 6.66$ (bs, $1 \mathrm{H}), 6.90(\mathrm{bt}, J=5.9 \mathrm{~Hz}, 1 \mathrm{H}), 7.17-7.22$ (m, 2H), $7.28-7.39(\mathrm{~m}, 7 \mathrm{H}) ;{ }^{13} \mathrm{C}$ NMR $(100$ $\left.\mathrm{MHz}, \mathrm{CDCl}_{3}\right) \delta(\mathrm{ppm}) 28.3,38.4,41.3,42.6,43.1,48.0,67.2,80.6,118.8,128.3,128.4,128.5$, 
$128.6,132.2,135.1,137.8,150.9,152.7,166.7,169.3,169.5$; ESI-MS $m / z 525[\mathrm{M}+\mathrm{H}]^{+}, 542$ $\left[\mathrm{M}+\mathrm{H}_{2} \mathrm{O}\right]^{+}, 547[\mathrm{M}+\mathrm{Na}]^{+}, 563[\mathrm{M}+\mathrm{K}]^{+}$.

2-(2-(1-(4-tert-butoxycarbonylaminobenzylcarbamoyl)-4-oxoazetidin-2-yl) acetamido) acetic acid (41)

Following GP2 compound 40 (22 mg, $0.042 \mathrm{mmol})$ yielded compound 41 as a white solid (18 mg, 99\%). Mp $100-103^{\circ} \mathrm{C}$; IR (film, $\left.\mathrm{cm}^{-1}\right)$ 3350, 1768, 1717, 1694, 1682; ${ }^{1} \mathrm{H}$ NMR (400 MHz, $\left.\mathrm{CD}_{3} \mathrm{OD}\right) \delta(\mathrm{ppm}) 1.51(\mathrm{~s}, 9 \mathrm{H}), 2.65(\mathrm{dd}, J=8.6,14.6 \mathrm{~Hz}, 1 \mathrm{H}), 2.95-3.03(\mathrm{~m}, 1 \mathrm{H}), 3.05-3.14$ $(\mathrm{m}, 1 \mathrm{H}), 3.24(\mathrm{dd}, J=5.4,16.0 \mathrm{~Hz}, 1 \mathrm{H}), 3.86\left(\mathrm{~d}, J_{\mathrm{AB}}=19.9 \mathrm{~Hz}, 1 \mathrm{H}\right), 3.91\left(\mathrm{~d}, J_{\mathrm{AB}}=19.9 \mathrm{~Hz}\right.$, $1 \mathrm{H}), 4.27-4.39(\mathrm{~m}, 3 \mathrm{H}), 7.21(\mathrm{~d}, J=7.8 \mathrm{~Hz}, 2 \mathrm{H}), 7.35(\mathrm{~d}, J=7.8 \mathrm{~Hz}, 2 \mathrm{H}), 8.86(\mathrm{bs}, 1 \mathrm{H}) ;{ }^{13} \mathrm{C}$ NMR (100 MHz, $\left.\mathrm{CDCl}_{3}\right) \delta$ (ppm) 28.7, 30.7, 39.1, 43.0, 43.8, 49.3, 80.8, 119.9, 129.0, 134.0, $139.8,152.5,155.3,168.1,172.3,173.0 ;$ ESI-MS $m / z 435[\mathrm{M}+\mathrm{H}]^{+}, 457[\mathrm{M}+\mathrm{Na}]^{+}$.

Benzyl 3-(2-(1-((4-((tert-butoxycarbonyl)amino)benzyl)carbamoyl)-4-oxoazetidin-2-yl) acet amido)propanoate (42)

Carboxylic acid 32 (62 mg, 0.164 mmol, 1 equiv) was dissolved in a mixture of $\mathrm{CH}_{2} \mathrm{Cl}_{2}(1.85$ $\mathrm{mL})$ and $\mathrm{CH}_{3} \mathrm{CN}(0.36 \mathrm{~mL})$ under nitrogen. DCC (32 mg, $0.181 \mathrm{mmol}, 1.1$ equiv) was then added at $0^{\circ} \mathrm{C}$. It was followed by the dropwise addition of a previously prepared solution of beta alanine benzylester $p$-toluenesulfonate salt $(86 \mathrm{mg}, 0.246 \mathrm{mmol}, 1.5$ equiv) and TEA (37 $\mu \mathrm{L}$, $0.262 \mathrm{mmol}, 1.6$ equiv) in $\mathrm{CH}_{2} \mathrm{Cl}_{2}(2 \mathrm{~mL})$. After addition of catalytic DMAP (4 mg, $0.033 \mathrm{mmol}$, 0.2 equiv), the solution was warmed to $\mathrm{rt}$ and left under stirring overnight. After complete 
consumption of the starting material $(16 \mathrm{~h})$ the mixture was quenched with $\mathrm{H}_{2} \mathrm{O}$ and extracted with $\mathrm{CH}_{2} \mathrm{Cl}_{2}(3 \times 10 \mathrm{~mL})$. The collected organic layers were dried on $\mathrm{Na}_{2} \mathrm{SO}_{4}$ and filtered. The crude was suspended in AcOEt and the solid residual dicyclohexylurea was eliminated by filtration. The organic layer was concentrated in vacuum and purified by flash-chromatography (AcOEt/ $\mathrm{CH}_{2} \mathrm{Cl}_{2}$ 70:30) yielding compound $42(65 \mathrm{mg}, 74 \%)$ as a light yellow waxy solid. IR

(film, $\mathrm{cm}^{-1}$ ) 3434, 1767, 1726, 1698, 1665; ${ }^{1} \mathrm{H}$ NMR (400 MHz, $\left.\mathrm{CDCl}_{3}\right) \delta(\mathrm{ppm}) 1.50(\mathrm{~s}, 9 \mathrm{H})$, $2.49-2.61(\mathrm{~m}, 3 \mathrm{H}), 2.96-3.02(\mathrm{~m}, 2 \mathrm{H}), 3.19(\mathrm{dd}, J=5.6,16.3 \mathrm{~Hz}, 1 \mathrm{H}), 3.41-3.55(\mathrm{~m}, 2 \mathrm{H})$, $4.25-4.28(\mathrm{~m}, 1 \mathrm{H}), 4.32(\mathrm{dd}, J=5.8,14.8 \mathrm{~Hz}, 1 \mathrm{H}), 4.37(\mathrm{dd}, J=5.2,14.8 \mathrm{~Hz}, 1 \mathrm{H}), 5.11(\mathrm{~s}$, 2H), 6.57 (bt, $J=5.8 \mathrm{~Hz}, 1 \mathrm{H}), 6.66(\mathrm{bs}, 1 \mathrm{H}), 6.88(\mathrm{bt}, J=5.9 \mathrm{~Hz}, 1 \mathrm{H}), 7.18(\mathrm{~d}, J=8.4 \mathrm{~Hz}, 2 \mathrm{H})$, $7.29-7.37(\mathrm{~m}, 7 \mathrm{H}) ;{ }^{13} \mathrm{C} \mathrm{NMR}\left(100 \mathrm{MHz}, \mathrm{CDCl}_{3}\right) \delta(\mathrm{ppm}) 28.3,33.9,34.9,38.7,42.6,43.1$, $48.0,66.5,80.5,118.8,128.2,128.3,128.4,128.6,132.2,135.5,137.8,150.7,152.7,166.7$, 169.0, 172.0; ESI-MS $m / z 539[\mathrm{M}+\mathrm{H}]^{+}, 561[\mathrm{M}+\mathrm{Na}]^{+}$.

\section{3-(2-(1-((4-((tert-butoxycarbonyl)amino)benzyl)carbamoyl)-4-oxoazetidin-2-yl)acetamido)} propanoic acid (43)

Following GP2 compound 42 (22 mg, $0.040 \mathrm{mmol})$ yielded compound 43 as a white solid (18 mg, 99\%). Mp $77-79^{\circ} \mathrm{C}$; IR (film, $\mathrm{cm}^{-1}$ ) 3370, 1768, 1696, 1614; ${ }^{1} \mathrm{H}$ NMR (400 MHz, $\mathrm{CD}_{3} \mathrm{OD}$ ) $\delta(\mathrm{ppm}) 1.51(\mathrm{~s}, 9 \mathrm{H}), 2.49(\mathrm{t}, J=6.6 \mathrm{~Hz}, 2 \mathrm{H}), 2.56(\mathrm{dd}, J=8.4,14.7 \mathrm{~Hz}, 1 \mathrm{H}), 2.92(\mathrm{dd}, J=2.9$, $16.1 \mathrm{~Hz}, 1 \mathrm{H}), 2.99(\mathrm{dd}, J=4.3,14.7 \mathrm{~Hz}, 1 \mathrm{H}), 3.23(\mathrm{dd}, J=5.7,16.1 \mathrm{~Hz}, 1 \mathrm{H}), 3.41(\mathrm{t}, J=6.6 \mathrm{~Hz}$, 2H), $4.27-4.30(\mathrm{~m}, 1 \mathrm{H}), 4.33-4.39(\mathrm{~m}, 2 \mathrm{H}), 7.21(\mathrm{~d}, J=8.5 \mathrm{~Hz}, 2 \mathrm{H}), 7.35(\mathrm{~d}, J=8.5 \mathrm{~Hz}, 2 \mathrm{H})$; ${ }^{13} \mathrm{C}$ NMR (100 MHz, CD $\left.{ }_{3} \mathrm{OD}\right) \delta$ (ppm) 28.7, 34.8, 36.4, 39.4, 43.0, 43.8, 49.4, 81.0, 119.9, 129.0, 134.0, 139.8, 152.4, 155.3, 168.1, 171.9; ESI-MS m/z $449[\mathrm{M}+\mathrm{H}]^{+}, 471[\mathrm{M}+\mathrm{Na}]^{+}$. 


\section{Benzyl 3-(2-(1-((4-(((tert-butoxycarbonyl)amino)methyl)phenyl)carbamoyl)-4-oxoazetidin-2-}

yl)acetamido)propanoate (45)

Carboxylic acid 44 (86 mg, $0.23 \mathrm{mmol}, 1$ equiv) was dissolved in a mixture of $\mathrm{CH}_{2} \mathrm{Cl}_{2}(2.7 \mathrm{~mL})$ and $\mathrm{CH}_{3} \mathrm{CN}(0.5 \mathrm{~mL})$ under nitrogen. DCC (52 mg, $0.25 \mathrm{mmol}, 1.1$ equiv) was then added at $0^{\circ} \mathrm{C}$. It was followed by the dropwise addition of a previously prepared solution of $\beta$-alanine benzylester $p$-toluenesulfonate salt ( $123 \mathrm{mg}, 0.35 \mathrm{mmol}, 1.5$ equiv) and TEA ( $52 \mu \mathrm{L}, 0.37 \mathrm{mmol}$, 1.6 equiv) in $\mathrm{CH}_{2} \mathrm{Cl}_{2}(2.9 \mathrm{~mL})$. After addition of catalytic DMAP (6 mg, $0.046 \mathrm{mmol}, 0.2$ equiv), the solution was warmed to rt and left under stirring overnight. After complete consumption of the starting material $(16 \mathrm{~h})$ the mixture was quenched with $\mathrm{H}_{2} \mathrm{O}$ and extracted with $\mathrm{CH}_{2} \mathrm{Cl}_{2}(3 \times 10$ $\mathrm{mL}$ ). The collected organic layers were dried on $\mathrm{Na}_{2} \mathrm{SO}_{4}$ and filtered. The crude was suspended in AcOEt and the solid residual dicyclohexylurea was eliminated by filtration. The organic layer was concentrated in vacuum and purified by flash-chromatography $\left(\mathrm{CH}_{2} \mathrm{Cl}_{2} / \mathrm{AcOEt} 80: 20\right.$ to 50:50) yielding compound $\mathbf{4 5}(88 \mathrm{mg}, 71 \%)$ as a light yellow waxy solid.

IR (film, $\mathrm{cm}^{-1}$ ) 3333, 1767, 1710, 1661, 1604; ${ }^{1} \mathrm{H}$ NMR (400 MHz, $\left.\mathrm{CDCl}_{3}\right) \delta$ (ppm) 1.44 (s, 9H), $2.54-2.60(\mathrm{~m}, 3 \mathrm{H}), 3.04(\mathrm{dd}, J=3.5,14.8 \mathrm{~Hz}, 1 \mathrm{H}), 3.08(\mathrm{dd}, J=3.1,16.3 \mathrm{~Hz}, 1 \mathrm{H}), 3.28(\mathrm{dd}, J$ $=5.7,16.4 \mathrm{~Hz}, 1 \mathrm{H}), 3.50(\mathrm{q}, J=6.1 \mathrm{~Hz}, 2 \mathrm{H}), 4.21-4.25(\mathrm{~m}, 2 \mathrm{H}), 4.33-4.38(\mathrm{~m}, 1 \mathrm{H}), 4.89(\mathrm{bt}$, $J=6.0 \mathrm{~Hz}, 1 \mathrm{H}), 5.06(\mathrm{~s}, 2 \mathrm{H}), 6.50(\mathrm{bt}, J=5.8 \mathrm{~Hz}, 1 \mathrm{H}), 7.20(\mathrm{~d}, J=8.3 \mathrm{~Hz}, 2 \mathrm{H}), 7.30-7.35(\mathrm{~m}$, $5 \mathrm{H}), 7.39(\mathrm{~d}, J=8.3 \mathrm{~Hz}, 1 \mathrm{H}), 8.48(\mathrm{bs}, 1 \mathrm{H}) ;{ }^{13} \mathrm{C} \mathrm{NMR}\left(100 \mathrm{MHz}, \mathrm{CDCl}_{3}\right) \delta(\mathrm{ppm}) ; 28.3,33.9$, $34.9,38.5,42.7,44.1,48.4,66.5,79.4,119.9,128.2,128.2,128.4,128.6,135.0,135.5,136.0$, 148.0, 155.8, 167.1, 168.8, 172.1; ESI-MS $m / z 539[\mathrm{M}+\mathrm{H}]^{+}, 561[\mathrm{M}+\mathrm{Na}]^{+}$. 


\section{3-(2-(1-((4-(((tert-butoxycarbonyl)amino)methyl)phenyl)carbamoyl)-4-oxoazetidin-2-}

\section{yl)acetamido)propanoic acid (46)}

Following GP2 compound 45 (79 mg, $0.150 \mathrm{mmol}$ ) yielded compound 46 as a waxy white solid (67 mg, 99\%). IR (film, $\left.\mathrm{cm}^{-1}\right)$ 3346, 1773, 1740, 1710, 1688, 1655; ${ }^{1} \mathrm{H}$ NMR (400 MHz, $\left.\mathrm{CD}_{3} \mathrm{OD}\right) \delta(\mathrm{ppm}) 1.45(\mathrm{~s}, 9 \mathrm{H}), 2.50(\mathrm{t}, J=6.6 \mathrm{~Hz}, 2 \mathrm{H}), 2.62(\mathrm{dd}, J=14.8,8.2 \mathrm{~Hz}, 1 \mathrm{H}), 3.01$ (ddd, $J=19.3,15.5,3.7 \mathrm{~Hz}, 2 \mathrm{H}), 3.30(\mathrm{dd}, J=5.8 \mathrm{~Hz}, 1 \mathrm{H}), 3.43(\mathrm{t}, J=6.7 \mathrm{~Hz}, 2 \mathrm{H}), 4.18(\mathrm{~s}, 2 \mathrm{H})$, $4.34-4.43(\mathrm{~m}, 1 \mathrm{H}), 7.23(\mathrm{~d}, J=8.4 \mathrm{~Hz}, 2 \mathrm{H}), 7.43(\mathrm{~d}, J=8.4 \mathrm{~Hz}, 2 \mathrm{H}) ;{ }^{13} \mathrm{C}$ NMR $(100 \mathrm{MHz}$, $\left.\mathrm{CD}_{3} \mathrm{OD}\right) \delta(\mathrm{ppm}) 28.8,34.8,36.5,39.4,43.1,44.5,49.6,84.3,121.1,128.8,136.9,137.4,149.7$, 163.7, 168.5, 171.9, 175.6; ESI-MS m/z 561 [M+TFA-H]'.

\section{Cell culture}

SK-MEL-24 cells (expressing $\alpha_{v} \beta_{3}$ integrin) were routinely grown in Eagle's Minimum Essential Medium (EMEM, Cambrex, Walkersville, MD, USA) supplemented with $10 \%$ foetal bovine serum (FBS; Life technologies, Carlsbad, CA, USA), non-essential aminoacids and sodium pyruvate. K562 cells (expressing $\alpha_{5} \beta_{1}$ integrin), Jurkat E6.1 human T cells (expressing $\alpha_{4} \beta_{1}$ and $\alpha_{\mathrm{L}} \beta_{2}$ integrins), HEL cells (expressing $\alpha_{\mathrm{II}} \beta_{3}$ integrin), MCF7 cells (expressing $\alpha_{\mathrm{v}} \beta_{5}$ integrin) and HT-29 cells (expressing $\alpha_{v} \beta_{6}$ integrin) were cultured in RPMI-1640 (Life technologies) and glutamine with $10 \%$ FBS. HEL cells were a kind gift of Dr. Cecilia Prata and Laura Zambonin, while MCF7 and HT-29 cells were a kind gift of Prof. Natalia Calonghi. HEK293 cells were grown in EMEM supplemented with 10\% FBS, non-essential aminoacids and L-glutamine. Cells were kept at $37^{\circ} \mathrm{C}$ under $5 \% \mathrm{CO}_{2}$ humidified atmosphere; $40 \mathrm{~h}$ prior to experiments, $\mathrm{K} 562$ cells were treated with $25 \mathrm{ng} / \mathrm{mL}$ PMA (Phorbol 12-myristate 13-acetate, Sigma Aldrich SRL, Milan, 
Italy) to induce differentiation and to increase expression of $\alpha_{5} \beta_{1}$ integrin on cell surface . All cell lines were purchased from American Type Culture Collection (ATCC, Rockville, MD, USA).

These cell models are widely used to investigate potential agonists or antagonists of integrinmediated cell adhesion. ${ }^{14,38-41,49,65,66,67}$

\section{Cell adhesion assays}

The assays were performed as described in Ref. 14 Briefly, for adhesion assay on SK-MEL-24, K562 and HT-29 cells 96-well plates (Corning Costar, Celbio, Milan, Italy) were coated by passive adsorption with fibronectin $(10 \mu \mathrm{g} / \mathrm{mL})$ overnight at $4{ }^{\circ} \mathrm{C}$, while for MCF7 or HEL cells plates were coated with fibrinogen $(10 \mu \mathrm{g} / \mathrm{mL})$. Cells were counted and pre-incubated with various concentrations of each compound or with the vehicle (methanol) for $30 \mathrm{~min}$ at room temperature to reach ligand-receptor equilibrium. Then, the cells were plated (50,000 cells/well; for HEL cells 100000 cells/well) and incubated at room temperature for $1 \mathrm{~h}$ in fibronectin/fibrinogen-coated plates. All the wells were then washed with $1 \%$ BSA (bovine serum albumin) in PBS (phosphate-buffered saline) to remove non-adherent cells, and $50 \mu \mathrm{L}$ hexosaminidase [4-nitrophenyl-N-acetyl-b-d-glucosaminide dissolved at a concentration of 7.5 $\mathrm{mM}$ in $0.09 \mathrm{M}$ citrate buffer $(\mathrm{pH} 5) 0.5 \%$ Triton $\mathrm{X}-100$ in $\mathrm{H}_{2} \mathrm{O}$ ] was added. This product is a chromogenic substrate for $\beta$-N-acetylglucosaminidase, whereby it is transformed into 4nitrophenol; absorbance was measured at $405 \mathrm{~nm}$ after the addition of stopping solution [50 $\mathrm{mM}$ glycine and $5 \mathrm{mM}$ EDTA (pH 10.4)], and the plates were read in a Victor ${ }^{2}$ Multilabel Counter (PerkinElmer, Waltham, MA, USA). Reference compounds 50 (BIO-1211), Ac-Asp-Arg-LeuAsp-Ser-OH (48) and cyclo(Arg-Gly-Asp-D-Phe-Val) (49) were purchased from Bachem 
(Bubendorf, Switzerland), while H-Gly-Arg-Gly-Asp-Thr-Pro-OH (47) was from Sigma. Under these conditions, no significant cell adhesion was observed for bovine serum albumin (BSA)coated plates (negative control) or nonspecific ligand-coated plates (data not shown).

For adhesion assays on Jurkat E6.1 cells, black 96-well plates were coated overnight at $4{ }^{\circ} \mathrm{C}$ with VCAM-1 or ICAM-1 (both $5 \mu \mathrm{g} / \mathrm{mL}$ ) to study respectively adhesion mediated by $\alpha_{4} \beta_{1}$ and $\alpha_{\mathrm{L}} \beta_{2}$ integrins. Jurkat E6.1 cells were counted and stained with CellTracker green CMFDA (12.5 $\mu \mathrm{M}$, 30 min at $37{ }^{\circ} \mathrm{C}$, Life Technologies. After three washes, Jurkat E6.1 cells were pre-incubated with various concentrations of each compound or with the vehicle (methanol) for $30 \mathrm{~min}$ at $37^{\circ} \mathrm{C}$. Cells were plated $(500,000 /$ well $)$ on coated wells and incubated for $30 \mathrm{~min}$ at $37^{\circ} \mathrm{C}$. After three washes, adhered cells were lysed with $0.5 \%$ Triton X-100 in PBS (30 min at $4{ }^{\circ} \mathrm{C}$ ) and fluorescence was measured (Ex485 nm/Em535 nm).

Experiments were carried out in quadruplicate and repeated at least three times. Data analysis and $\mathrm{EC}_{50}$ or $\mathrm{IC}_{50}$ values were calculated using GraphPad Prism 5.0 (GraphPad Software, San Diego, CA, USA).

In another set of experiment, Jurkat E6.1 (500,000 cells/well) or K562 cells (50,000 cells/well) were plated in 96-wells plate previously coated directly with the most effective agonists under examination, dissolved in methanol to the final concentration of $10 \mu \mathrm{g} / \mathrm{mL}$. When required, neutralizing antibodies $\alpha_{5}$ (Chemicon International, Millipore) or $\alpha_{4}$ (Santa Cruz Biotechnology) integrin subunit (both $10 \mu \mathrm{g} / \mathrm{mL}$ ) or a selective $\alpha_{\mathrm{IIb}} \beta_{3}$ integrin antagonist Tirofiban $(\mathbf{5 1})^{14}(5-10$ $\mu \mathrm{M})$ (Sigma Aldrich) were added to the cells 10 min before plating cells on wells coated with $\beta$ lactam agonists. The number of adherent cells was determined as above described. 


\section{Competitive solid-phase binding assay on isolated integrins}

To determine integrin-ligand interactions, a solid-phase binding assay was performed using purified soluble integrins and coated extracellular matrix proteins, as previously described with the following modifications. ${ }^{18}$ Flat, black 96 -well plates were coated by passive adsorption with extracellular matrix ligands in carbonate buffer $\left(15 \mathrm{mM} \mathrm{Na}_{2} \mathrm{CO}_{3}, 35 \mathrm{mM} \mathrm{NaHCO}, \mathrm{pH} 9.6\right)$ overnight at $4{ }^{\circ} \mathrm{C}$ as follow: fibronectin $0.5 \mu \mathrm{g} / \mathrm{mL}$ for $\alpha_{\mathrm{v}} \beta_{3}, \alpha_{\mathrm{v}} \beta_{6}$ and $\alpha_{5} \beta_{1}$, fibrinogen $10 \mu \mathrm{g} / \mathrm{mL}$ for $\alpha_{\mathrm{IIb}} \beta_{3}$ and $\alpha_{\mathrm{v}} \beta_{5}$, ICAM-1 for $\alpha_{\mathrm{L}} \beta_{2}$. After three washes with PBST buffer (137 mM NaCl, 2.7 $\mathrm{mM} \mathrm{KCl}, 10 \mathrm{mM} \mathrm{Na} 2 \mathrm{PO}_{4}, 2 \mathrm{mM} \mathrm{KH}_{2} \mathrm{PO}_{4}, 0.01 \%$ Tween 20, pH 7.4), wells were blocked with TSB buffer (20 mM Tris-HCl, $150 \mathrm{mM} \mathrm{NaCl}, 1 \mathrm{mM} \mathrm{CaCl} 2,1 \mathrm{mM} \mathrm{MgCl} 2,1 \mathrm{mM} \mathrm{MnCl} 2, \mathrm{pH} 7.5$, $1 \%$ BSA) for 1 hour at room temperature. Integrins were purified as described in Supporting Information. Purified integrins were incubated with $\beta$-lactam compounds, tested at different concentrations $\left(10^{-4}-10^{-10} \mathrm{M}\right)$, in the coated wells for one hour at room temperature. Preliminary assays ascertained the optimal concentration of each integrin binding to respective ECM $\left(3 \mu \mathrm{g} / \mathrm{mL}\right.$ for $\alpha_{\mathrm{v}} \beta_{3}$ and $\alpha_{\mathrm{v}} \beta_{5} ; 5 \mu \mathrm{g} / \mathrm{mL}$ for $\alpha_{\mathrm{v}} \beta_{6}$ and $\alpha_{\mathrm{IIb}} \beta_{3} ; 10 \mu \mathrm{g} / \mathrm{mL}$ for $\alpha_{5} \beta_{1}$ and $\left.\alpha_{\mathrm{L}} \beta_{2}\right)$. The plate was washed three times with PBST buffer and primary antibody was added for 1 hour incubation at room temperature. Integrin antibodies were purchased from: Calbiochem for $\alpha_{\mathrm{v}}$ integrin (1:200 dilution), BD Bioscience for $\alpha_{\mathrm{IIb}} \beta_{3}$ and $\alpha_{5} \beta_{1}$ integrins (1:200 and 1:100 dilution, respectively), Chemicon International for $\alpha_{\mathrm{L}} \beta_{2}$ (1:100 dilution). Then, secondary antibody AlexaFluor488 conjugated (1:400 dilution, ThermoFisher Scientific) was added after three washes with PBST buffer and incubated 1 hour at room temperature. After washing three times, fluorescence was measured (Ex485 nm/Em535 nm) in a Victor ${ }^{2}$ Multilabel Counter. 
Experiments were carried out in duplicate and repeated at least three times. Data analysis and $\mathrm{IC}_{50}$ values were calculated using GraphPad Prism 5.0 (GraphPad Software, San Diego, CA, USA).

\section{Scintillation proximity-binding assay (SPA) ${ }^{49}$}

To detect competitive binding of drugs to soluble ${ }^{125}$ I-human FN ( $\mathrm{M}_{\mathrm{w}}$ approximately $\left.440 \mathrm{kDa}\right)$ bound to an antibody-captured integrin complex we employed a SPA assay, as previously described. ${ }^{49}$ Briefly, experiments were carried out in scintillation vials; in each vial $1 \mathrm{mg} / 50 \mathrm{ml}$ antirabbit-coated beads (GE Healthcare Life Sciences), $200 \mathrm{mg}$ of rabbit anti- $\alpha_{4}$ integrin antibody (SantaCruz Biotechnology) and approximately $100 \mathrm{mg}$ of purified $\alpha_{4} \beta_{1}$ integrin were added. The $\alpha_{4} \beta_{1}$ integrin was extracted and purified from HEK293 cells stably expressing the $\alpha_{4}$ integrin subunit (these cells endogenously express the $\beta 1$ integrin subunit: data not shown). The cells were collected with a cell scraper; then membrane proteins were extracted and $\alpha_{4} \beta_{1}$ integrin was purified by affinity chromatography, as described. ${ }^{68}$ The binding buffer contained Tris-HCl $25 \mathrm{mM} \quad \mathrm{pH} \quad 7,5 ; \mathrm{CaCl}_{2} 1 \mathrm{mM} ; \mathrm{MgCl}_{2} 1 \mathrm{mM} ; \mathrm{MnCl}_{2} \quad 1 \mathrm{mM} ; \quad \mathrm{BSA} \quad 2 \% \quad(\mathrm{w} / \mathrm{v}) ;$ phenylmethanesulfonyl fluoride (PMSF) $1 \mathrm{mM}$; aprotinin $1 \mathrm{mg} / \mathrm{ml}$; leupeptin $50 \mathrm{mM}$. First, we allowed for the slow interaction between the $\alpha_{4}$ integrin protein and the rabbit anti-human $\alpha_{4}$ integrin antibody by incubating them together for $1 \mathrm{~h}$ at $4{ }^{\circ} \mathrm{C}$. Then the antirabbit antibody binding beads were added, and the solution containing the three components was incubated for 2 $\mathrm{h}$ at $4{ }^{\circ} \mathrm{C}$ in the dark. From this point on, all incubations were conducted at room temperature. $\left[{ }^{125} \mathrm{I}\right]-\mathrm{FN}$ was added to the vials, which were then incubated overnight on a shaker in the dark. Nonspecific binding was determined in the presence of the specific $\alpha_{4} \beta_{1}$ integrin antagonist $\mathbf{5 0}$ 
(BIO-1211) (100 mM). The samples were read using a LS 6500 multipurpose scintillation counter (Beckham Coulter, Fullerton, CA, USA). Experiments were carried out in triplicate and repeated at least three times. Data analysis and $\mathrm{IC}_{50}$ values were calculated using $\mathrm{GraphPad}$ Prism 5.0 (GraphPad Software, San Diego, CA, USA).

\section{Flow cytometry analysis. ${ }^{69}$}

Jurkat E6.1 cells were suspended in 1\% BSA/HBSS (Hanks' Balanced Salt Solution, LifeTechnologies) at the concentration of $10^{6}$ cells $/ \mathrm{mL}(100 \mu \mathrm{L} /$ sample $)$ and incubated with different concentration of the most effective compounds towards $\alpha_{4} \beta_{1}$ integrin, for $30 \mathrm{~min}$ at $37^{\circ} \mathrm{C}$. At the end of the incubation, Phycoerythrin (PE)-labeled HUTS-21 antibody (PE mouse anti-human CD29 antibody, BD Pahrmingen) (20 $\mu \mathrm{l} /$ sample) was added and the cells were incubated for $45 \mathrm{~min}$ at room temperature. After two washes with $1 \% \mathrm{BSA} / \mathrm{HBSS}$, cells were resuspended in PBS and analyzed in a Guava EasyCyte (Millipore) flow cytometry and 10,000 cells/sample were analyzed. Data were normalized with the relative fluorescence for nonspecific binding evaluated by exposing the cells to an isotype control $\mathrm{mAb}$ and set to 0 .

\section{HEK293 cells transfection}

HEK293 cells (not expressing $\alpha_{\mathrm{v}}$ nor $\beta_{3}$ integrin) were plated in $10 \mathrm{~mm}$ dishes and at $50-60 \%$ confluence were transiently transfected with $\alpha_{\mathrm{v}}{ }^{70}$ and $\beta_{3}$ plasmids using Lipofectamine2000 transfection reagent (LifeTechnologies). After $48 \mathrm{~h}$ from transfection, HEK293 $+\alpha_{v} \beta_{3}$ cells were assessed to verify integrins expression: cells were incubated with a saturating concentration of 
anti-human $\alpha_{\mathrm{v}}$ or anti-human $\beta_{3}$ antibody for $30 \mathrm{~min}$ at $4{ }^{\circ} \mathrm{C}$; subsequently, a fluorescein isothiocyanate (FITC)-conjugated secondary antibody was added for $45 \mathrm{~min}$ at $4{ }^{\circ} \mathrm{C}$ in the dark. After each incubation step, the cells were washed with $1 \%$ BSA/HBSS. Finally, the cells were resuspended in PBS and analyzed in a Guava EasyCyte (Millipore) flow cytometry and 10,000 cells/sample were analyzed (data not shown). $\alpha_{\mathrm{v}}$ Integrin plasmid was a kind gift from Michael Davidson (Addgene plasmid \#57345) while $\beta_{3}$ integrin was a kind gift of Prof. S.J. Shattil.

\section{Western blot analysis}

Western blot analysis was performed as previously described ${ }^{39}$ with the following modifications. K562 or Jurkat E6.1 cells were incubated in RPMI-1640 with 1\% FBS for 16 h, while HEK $293+\alpha_{v} \beta_{3}$ cells were serum starved in EMEM for $18 \mathrm{~h}$. Plates were coated with fibronectin $(10 \mu \mathrm{g} / \mathrm{mL})$ and blocked with $1 \%$ BSA. Subsequently, $4 \times 10^{6}$ cells were pre-incubated with different concentrations of the most effective compounds for $60 \mathrm{~min}$ and then were allowed to adhere for $1 \mathrm{~h}$ on fibronectin. Cells treated with agonists were not incubated with fibronectin. Thereafter, the cells were lysed in mammalian protein extraction reagent (M-PER; Pierce, Rockford, IL, USA) supplemented with Phosphatase Inhibitor Cocktail (Sigma Aldrich SRL) for $10 \mathrm{~min}$ at $4^{\circ} \mathrm{C}$ by gentle shaking. Cell debris was removed by centrifugation (14 $000 \mathrm{~g}$ for $15 \mathrm{~min}$ at $4{ }^{\circ} \mathrm{C}$ ), and protein concentration was determinated by BCA assay (Pierce, Rockford, IL, USA). Protein extracts were denatured at $95{ }^{\circ} \mathrm{C}$ for 3 min before loading and separation by $12 \%$ SDSPAGE. The membranes were blocked in 5\% BSA for $1 \mathrm{~h}$ and incubated with anti-phospho-ERK 1/2 (extracellular signal-regulated kinase 1/2) (1:1000) (Cell Signaling Technology, Danvers, MA, USA) or anti-total ERK1/2 antibodies (1:1000) (Cell Signaling Technology) overnight at 
$4^{\circ} \mathrm{C}$. Next, the membranes were incubated with peroxidase-conjugated secondary antibodies at a 1:8,000 dilution (Santa Cruz Biotechnology). Digital images were acquired and analyzed according to a previously reported method..$^{71}$

\section{Apoptosis detection}

Phycoerythrin-conjugated annexin V (annexin V-PE) and 7-amino-actynomicin D (7-AAD; Guava Nexin Reagent, Millipore) were used to determine the percentage of viable, earlyapoptotic and late apoptotic/necrotic cells by flow cytometry. After three hour incubation, cells were collected and resuspended in $100 \mu \mathrm{l}$ of complete medium. The cells were then stained with $100 \mu \mathrm{l}$ of Nexin reagent for $20 \mathrm{~min}$ at room temperature in the dark, following manufacturer's instructions, and analyzed on a Guava easyCyte 5 flow cytometer (Millipore). Three populations of cells can be distinguished by this assay: viable cells (annexin V-PE and 7-AAD negative), early apoptotic cells (annexin V-PE positive and 7-AAD negative), and late stages apoptosis or necrotic cells (annexin V-PE and 7-AAD positive).

\section{Molecular Docking}

Docking calculations were run using the Schrödinger suite of programs (http://www.schrodinger.com) through the Maestro graphical interface.

Ligand preparation. Ionized carboxylate and neutral aniline are suggested by the Epik version $2.2^{72}$ as the relevant protonation states at $\mathrm{pH}=7$ for the acid and basic pharmacophoric groups of compounds $\mathbf{1 5}$ and $\mathbf{5}$ according to predicted pKa values of 4.1 (mono-substituted ethanoic acid and 4-oxo-butanoic acid, respectively) and 4.5 (phenyl anilinium derivative). Ionized carboxylate and protonated benzylic amine are suggested by the Epik module as the relevant protonation states at $\mathrm{pH}=7$ for ligand $\mathbf{1}$ according to predicted $\mathrm{pKa}$ values of 4.1 (mono-substituted ethanoic 
acid) and 8.5 (benzylaminium derivative). These protonation states were considered for docking studies of the compounds.

Protein Setup. The crystal structure of the extracellular domain of the $\alpha_{v} \beta_{3}$ integrin in complex with Cilengitide and in the presence of the proadhesive ion $\mathrm{Mn}^{2+}$ (PDB entry $\left.1 \mathrm{~L} 5 \mathrm{G}\right)^{62}$ was used for docking studies. Docking was performed only on the globular head of the integrin because the headgroup of integrin has been identified in the X-ray structure as the ligand-binding region. The protein structure was set up for docking as follows; the protein was truncated to residues 41342 for chain $\alpha$ and residues $114-347$ for chain $\beta$. Due to a lack of parameters in Glide version 4.5, the $\mathrm{Mn}^{2+}$ ions in the experimental protein structure were modeled via replacement with $\mathrm{Ca}^{2+}$ ions. The resulting structure was prepared using the Protein Preparation Wizard of the graphical user interface Maestro and the OPLSAA force field.

Docking. The automated docking calculations were performed using Glide (Grid-based Ligand Docking with Energetics) ${ }^{61}$ within the framework of Impact version 4.5 in a standard precision mode (SP). The grid generation step started from the extracellular fragment of the X-ray structure of the $\alpha_{\mathrm{v}} \beta_{3}$ complex with Cilengitide, prepared as described in Protein Setup. The center of the grid-enclosing box was defined by the center of the bound ligand. The enclosing box dimensions, which are automatically deduced from the ligand size, fit the entire active site. For the docking step, the size of the bounding box for placing the ligand center was set to $12 \AA$. No further modifications were applied to the default settings. The Glide-Score function was used to select 10 poses for each ligand. Glide was initially tested for its ability to reproduce the crystallized binding geometry of Cilengitide. The program was successful in reproducing the experimentally found binding mode of this compound, as it corresponds to the best-scored pose (docking vs X-ray peptide backbone rmsd $=0.4 \AA$ ). To confirm our results, we built a new 
docking model for the $\alpha v \beta 3$ integrin using the 2016 software version (Glide version 7.0) that contains parameters for $\mathrm{Mn}^{2+}$ ions. The results provided by the new model are very similar to those obtained with the former model (as shown for example by the superimposition between the two models for compound $(R)-\mathbf{1}$ included in the Supporting Information as Figure S7).

\section{ASSOCIATED CONTENT}

Supporting Information contains Pharmacology (Figure S1 and S2), Integrin extraction and purification ); Stability data at $\mathrm{pH} 7.4$ and in serum for compounds 2 and $\mathbf{4}$. Docking models of compound ( $R$ )-1 using Glide v4.5 (integrin and MIDAS $\mathrm{Ca}^{2+}$ ion) and Glide v7.0 (integrin and

MIDAS $\mathrm{Mn}^{2+} ;{ }^{1} \mathrm{H}$ and ${ }^{13} \mathrm{C}$ NMR spectra of compounds $4,5,6,7,8,9,10,11,12,14,16,17,18$, $19,20,21,24,25,26,27,28,29,30,31,32,33,36,37,38,39,40,41,42,43,45$, and 46.

\section{AUTHOR INFORMATION}

\section{Corresponding Authors}

Prof. Daria Giacomini tel +39 0512099528 e-mail: daria.giacomini@,unibo.it

Prof. Santi Mario Spampinato tel+390512091851 e-mail: santi.spampinato@unibo.it

\section{Author Contributions}

The manuscript was written through contributions of all authors. All authors have given approval to the final version of the manuscript.

\section{Funding Sources}


All authors received funds from the project MIUR PRIN project 2010NRREPL: Synthesis and biomedical applications of tumor-targeting peptidomimetics. D.G., P.G., and S.P. also received funds from University of Bologna (RFO funding).

\section{ACKNOWLEDGMENT}

DG would like to thank L. Turrini, M. Moncelli, M. Nagakawa, S. Carpinelli, L. Merlo for technical assistance.

\section{ABBREVIATION USED}

RGD, arginyl-glycyl-aspartic acid tripeptide; NaHMDSA, sodium hexamethyldisilylamide; TEA, triethylamine; PTSA, pyridiniumparatoluensulfonic acid; EDC, N-(3dimethylaminopropyl)-N'-ethylcarbodiimide hydrochloride; DCC, dicyclohexylcarbodiimide; VCAM-1, vascular cell adhesion protein 1; ICAM, intercellular adhesion molecule 1; SD, standard deviation; c(-RGDfV), cyclo(-Arg-Gly-Asp-D-Phe-Val); fibronectin, FN;

\section{REFERENCES}

1 For recent reviews see: Arya, N; Jagdale, A. Y.; Patil, T. A.; Yeramwar, S. S.; Holikatti, S. S.; Dwivedi, J.; Shishoo, C. J.; Jain, K. S. The chemistry and biological potential of azetidin-2-ones. Eur. J. Med. Chem. 2014, 74, 619-656.

2 Galletti, P.; Giacomini, D. Monocyclic $\beta$-Lactams: New structures for new biological activities. Curr. Med. Chem. 2011, 18, 4265-4283. 
3 Mehta, P. D.; Sengar, N. P. S.; Pathak, A. K. 2-Azetidinone -a new profile of various pharmacological activities. Eur. J. Med. Chem. 2010, 45, 5541-5560.

4 Crauste, C.; Froeyen, M.; Anné, J.; Herdewijn P. Asymmetric synthesis of new $\beta$ lactam lipopeptides as bacterial signal peptidase I antagonists. Eur. J. Org. Chem. 2011, $3437-3449$.

5 Dražić, T.; Sachdev, V.; Leopold, C.; Patankar, J.V.; Malnar, M.; Hećimović, S.; Levak-Frank, S.; Habuš, I.; Kratky, D. Synthesis and evaluation of novel amide amino$\beta$-lactam derivatives as cholesterol absorption antagonists. Bioorg. Med. Chem. 2015, $23,2353-2359$.

6 Feledziak, M.; Michaux, C.; Lambert, D.M.; Marchand-Brynaert, J. An unprecedented reversible mode of action of $\beta$-lactams for the inhibition of human fatty acid amide hydrolase (hFAAH). Eur. J. Med. Chem. 2013, 60, 101-111.

7 O’Boyle, N. M.; Knox, A. J. S.; Price, T. T.; Williams D. C.; Zisterer, D. M.; Lloyd, D.G.; Meegan, M. J. Lead identification of $\beta$-lactam and related imine antagonists of the molecular chaperone heat shock protein 90. Bioorg. Med. Chem. 2011, 19, 60556068.

8 Galletti, P.; Quintavalla, A.; Ventrici, C.; Giannini, G.; Cabri, W.; Penco, S.; Gallo, G.; Vincenti, S.; Giacomini, D. Azetidinones as zinc-binding groups to design selective HDAC8 antagonists. ChemMedChem, 2009, 4, 1991-2001. 
9 Wong, P. C.; Crain, E. J.; Watson, C.A.; Schumacher, W.A. A small-molecule factor XIa antagonist produces antithrombotic efficacy with minimal bleeding time prolongation in rabbits. J. Thromb. Thrombolysis 2011, 32, 129-137.

10 Alcaide, B; Almendros, P; Aragoncillo, C. Highly reactive 4-membered ring nitrogencontaining heterocycles: synthesis and properties. Curr. Opin. Drug Di. De. 2010, 13, 685-697.

11 Aizpurua, J. M.; Ganboa, J. I.; Palomo, C.; Loinaz, I.; Oyarbide, J.; Fernandez, X.; Balentova, E.; Fratila, R. M.; Jimenez, A.; Miranda, J. I.; Laso, A.; Avila, S.; Castrillo, J. L. Cyclic RGD beta-lactam peptidomimetics induce differential gene expression in human endothelial cells. ChemBioChem 2011, 12, 401-405.

12 Aizpurua, J. M.; Oyarbide, J.; Fernandez, X.; Miranda, J. I.; Ganboa, J. I.; Avila, S.; Castrillo, J. L. Preparation of pro-angiogenic beta-lactams cyclotetrapeptides. Eur. Pat. Appl. 2012, EP 2407478 A1 20120118.

13 Aizpurua, J. M.; Ganboa, J. I.; Palomo, C.; Loinaz, I.; Miranda, J. I. Beta-Lactams RGD cyclopeptides containing gamma turns. PCT Int. Appl. 2006, WO 2006048473 A1 20060511.

14 Galletti, P.; Soldati, R.; Pori, M.; Durso, M.; Tolomelli, A.; Gentilucci, L.; Deianira Dattoli, S.; Baiula, M.; Santi Spampinato, M.; Giacomini, D. Targeting integrins $\alpha_{v} \beta_{3}$ and $\alpha_{5} \beta_{1}$ with new $\beta$-lactam derivatives. Eur. J. Med. Chem. 2014, 83, 284-293.

15 Plow, E.F.; Haas, T.A.; Zhang, L.; Loftus, J.; Smith, J.W. Ligand binding to integrins. J. Biol. Chem. 2000, 275, 21785-21788. 
16 Busk, M.; Pytela, R.; Sheppard, D. Characterization of the integrin $\alpha_{v} \beta_{6}$ as a fibronectin- binding protein. J. Biol. Chem. 1992, 267, 5790-5796.

17 Aumailley, M.; Gurrath, M.; Müller, G.; Calvete, J.; Timpl, R.; Kessler, H. Arg-GlyAsp constrained within cyclic pentapeptides. Strong and selective inhibitors of cell adhesion to vitronectin and laminin fragment P1. FEBS Lett. 1991, 291, 50-54.

18 Frank, A. O.; Otto, E.; Mas-Moruno, C.; Schiller, H. B.; Marinelli, L.; Cosconati, S.; Bochen, A.; Vossmeyer, D.; Zahn, G.; Stragies, R.; Novellino, E.; Kessler, H. Conformational control of integrin-subtype selectivity in isoDGR peptide motifs: a biological switch. Angew. Chem. Int. Ed. Engl. 2010, 49, 9278-9281.

19 Neubauer, S.; Rechenmacher, F.; Brimioulle, R.; Di Leva, F. S.; Bochen, A.; Sobahi, T. R.; Schottelius, M.; Novellino, E.; Mas-Moruno, C.; Marinelli, L.; Kessler, H. Pharmacophoric modifications lead to superpotent $\alpha_{v} \beta_{3}$ integrin ligands with suppressed $\alpha_{5} \beta_{1}$ activity. J. Med. Chem. 2014, 57, 3410-3417.

20 Bochen, A.; Marelli, U. K.; Otto, E.; Pallarola, D.; Mas-Moruno, C.; Di Leva, F. S.; Boehm, H.; Spatz, J. P.; Novellino, E.; Kessler, H.; Marinelli, L. Biselectivity of isoDGR peptides for fibronectin binding integrin subtypes $\alpha_{5} \beta_{1}$ and $\alpha_{v} \beta_{6}$ : conformational control through flanking amino acids. J. Med. Chem. 2013, 56, 15091519.

21 Maltsev, O. V.; Marelli, U. K.; Kapp, T. G.; Di Leva, F. S.; Di Maro, S.; Nieberler, M.; Reuning, U.; Schwaiger, M.; Novellino, E.; Marinelli, L.; Kessler, H. Stable peptides 
instead of stapled peptides: highly potent $\alpha_{\mathrm{v}} \beta_{6}$-selective integrin ligands. Angew. Chem. Int. Ed. Engl. 2016 55, 1535-1539.

22 Campbell, I. D.; Humphries, M. J. Molecular mechanism of inside-out integrin regulation Cold Spring Harb. Perspect. Biol. 2011, 3:a004994, doi :

10.1101/cshperspect.a004994.

23 Luo, B-H.; Carman, C. V.; Springer, T. A. Structural basis of integrin regulation and signaling. Ann. Rev. Immunol. 2007, 25, 619-647.

24 Hynes, R. O. Integrins: bidirectional, allosteric signaling machines. Cell 2002, 110, 673-687.

25 Barczyk, M.; Carracedo, S.; Gullberg, D. Integrins. Cell Tissue Res. 2010, 339, 269280.

26 Kim, S-H.; Turnbull, J.; Guimond, S. Extracellular matrix and cell signalling: the dynamic cooperation of integrin, proteoglycan and growth factor receptor. $J$. Endocrinol. 2011, 209, 139-151.

27 Sheldrake, H. M.; Patterson, L. H. Strategies to inhibit tumor associated integrin receptors: rationale for dual and multi-antagonists. J. Med. Chem. 2014, 57, 6301-6315.

28 Dong, X.; Hudson, N. E.; Lu, C.; Springer, T. A. Structural determinants of integrin $\beta$ subunit specificity for latent TGF- $\beta$. Nat. Struct. Mol. Biol. 2014, 1091-1096.

29 Yee K. L.; Weaver V. M.; Hammer D. A. Integrin-mediated signalling through the MAP-kinase pathway. IET Syst. Biol. 2008, 2, 8-15. 
30 Marelli, U. K.; Rechenmacher, F.; Sobahi, T. R.; Mas-Moruno, C.; Kessler, H. Tumor targeting via integrin ligands. Front. Oncol. 2013, 3,1-12, and references cited therein.

31 Celik, E.; Faridi, M. H.; Kumar, V.; Deep, S.; Moy, V. T.; Gupta, V. Agonist leukadherin-1 increases CD11b/CD18-dependent adhesion via membrane tethers. Biophys. J. 2013, 105, 2517-2727.

32 Khan, S. Q.; Guo, L.; Cimbaluk, D. J.; Elshabrawy, H.; Faridi, M. H.; Jolly, M.; George, J. F.; Agarwal, A.; Gupta, V. A. Small molecule $\beta 2$ integrin agonist improves chronic kidney allograft survival by reducing leukocyte recruitment and accompanying vasculopathy. Front. Med. 2014, 1, 1-11

33 Yang, W.; Carman, C.V.; Kim, M.; Salas, A.; Shimaoka, M.; Springer, T.A. A small molecule agonist of an integrin, $\alpha_{\mathrm{L}} \beta_{2}$. J. Biol. Chem. 2006, 281, 37904-37912.

34 Vanderslice, P.; Biediger, R. J.; Woodside, D. G.; Brown, W. S.; Khounlo, S.; Warier, N. D.; Gundlach, C.W.4 ${ }^{\text {th }}$; Caivano, A. R.; Bornmann, W. G.; Maxwell, D. S.; McIntyre, B.W.; Willerson, J. T.; Dixon, R.A. Small molecule agonist of very late antigen-4 (VLA-4) integrin induces progenitor cell adhesion. J. Biol. Chem. 2013, 288, 19414-19428.

35 Du, X. P.; Plow, E. F.; Frelinger, A. L. 3rd; O’Toole, T. E.; Loftus, J. C.; Ginsberg, M. H. Ligands "activate" integrin $\alpha_{\mathrm{II}} \beta_{3}$ (platelet GPIIb-IIIa). Cell 1991, 65, 409-416

36 Cabrele, C.; Martinek, T. A.; Reiser, O.; Berlicki, Ł. Peptides containing $\beta$-amino acid patterns: challenges and successes in medicinal chemistry. J. Med. Chem. 2014, 57, 9718-9739. 
37 Springer, T. A.; Wang, J.-H. The three-dimensional structure of integrins and their ligands, and conformational regulation of cell adhesion. Adv. Protein Chem. 2004, 68, 29-63.

38 Tolomelli, A.; Gentilucci, L. Mosconi, E.;Viola, A.; Dattoli, S. D.; Baiula, M.; Spampinato, S. M.; Belvisi, L.; Civera, M. Development of isoxazoline-containing peptidomimetics as dual $\alpha_{v} \beta_{3}$ and $\alpha_{5} \beta_{1}$ integrin ligands. ChemMedChem 2011, 6, 22642272.

39 Tolomelli, A.; Baiula, M.; Belvisi, L.; Viola, A.; Gentilucci, L.; Troisi, S.; Dattoli, S. D.; Spampinato, S. M.; Civera, M.; Juaristi, E. Modulation of $\alpha_{v} \beta_{3}$ and $\alpha_{5} \beta_{1}$ integrinmediated adhesion by dehydro- $\beta$-amino acids containing peptidomimetics. Eur. J. Med. Chem. 2013, 66, 258-268.

40 Benfatti, F.; Cardillo, G.; Fabbroni, S.; Galzerano, P.; Gentilucci, L.; Juris, R.; Tolomelli, A.; Baiula, M.; Sparta, A.; Spampinato, S. Synthesis and biological evaluation of non-peptide $\alpha_{v} \beta_{3} / \alpha_{5} \beta_{1}$ integrin dual antagonists containing 5,6dihydropyridin-2-one scaffolds. Bioorg. Med. Chem. 2007, 15, 7380-7390.

41 Tolomelli, A.; Baiula, M.; Viola, A.; Ferrazzano, L.; Gentilucci,L.; Dattoli, S. D.; Spampinato, S.; Juaristi, E.; Escudero, M. Dehydro- $\beta$-proline containing $\alpha 4 \beta 1$ integrin antagonists: stereochemical recognition in ligand-receptor interplay. ACS Med. Chem. Lett. 2015, 6, 701-706.

42 Lin, K. C.; Ateeq, H. S.; Hsiung, S. H.; Chong, L. T.; Zimermann, C. N.; Castro, A.; Lee, W. C.; Hammond, C. E.; Kalkunte, S.; Chen, L. L.; Pepinsky, R. B.; Leone, D. R.; 
Sprague, A. G.; Abraham, W. M.; Gill, A.; Lobb, R. R.; Adams, S. P. Selective, tight binding antagonists of integrin $\alpha_{4} \beta_{1}$ that inhibit allergic airway responses. $J$. Med. Chem. 1999, 42, 920-934.

43 Pitts, W. J.; Wityak, J.; Smallheer, J. M.; Tobin, A. E.; Jetter, J. W.; Buynitsky, J. S.; Harlow, P. P.; Solomon, K. A.; Corjay, M. H.; Mousa, S. A.; Wexler, R.R.; Jadhav, P. K. Isoxazolines as potent antagonists of the integrin $\alpha_{v} \beta_{3}$. J. Med. Chem. 2000, 43, 2740.

44 Broccolo, F.; Cainelli, G.; Caltabiano, G.; Cocuzza, C. E. A.; Fortuna, C. G.; Galletti, P.; Giacomini, D.; Musumarra, G.; Musumeci, R.; Quintavalla, A. Design, synthesis, and biological evaluation of 4-alkyliden-beta lactams: new products with promising antibiotic activity against resistant bacteria. J. Med. Chem. 2006, 49, 2804-2811.

45 Cainelli, G.; Giacomini, D.; Galletti, P.; Quintavalla, A. Synthesis of novel 4-(2oxoethylidene)azetidin-2-ones by a Lewis acid mediated reaction of acyldiazo compounds. Eur. J. Org. Chem. 2003, 1765-1774

46 Ito, Y.; Terashima, S. A highly stereoselective synthesis of a key intermediate of 1beta-methylcarbapenems employing the Reformatsky reaction of 3-(2bromopropionyl)-2-oxazolidone derivatives. Tetrahedron Lett. 1987, 28, 6625-6628.

47 Gurrath, M.; Müller, G.; Kessler, H.; Aumailley, M.; Timpl, R. Conformation/activity studies of rationally designed potent anti-adhesive RGD peptides. Eur. J. Biochem. 1992 210, 911-921. 
48 Mas-Moruno, C.; Rechenmacher, F.; Kessler, H. Cilengitide: the first anti-angiogenic small molecule drug candidate design, synthesis and clinical evaluation. Anticancer Agents Med. Chem. 2010, 753-68.

49 Qasem, A. R.; Bucolo, C.; Baiula, M.; Spartà, A.; Govoni, P.; Bedini, A.; Fascì, D.; Spampinato, S. Contribution of $\alpha_{4} \beta_{1}$ integrin to the antiallergic effect of levocabastine. Biochem. Pharmacol. 2008, 76, 751-762.

50 Bednar, R. A.; Gaul, S. L.; Hamill, T. G.; Egbertson, M. S.; Shafer, J. A.; Hartman, G. D.; Gould, R. J.; Bednar, B. Identification of low molecular weight GP IIb/IIIa antagonists that bind preferentially to activated platelets. J Pharmacol. Exp. Ther. 1998, $285,1317-1326$.

51 Adams, J.; Anderson, E. C.; Blackham, E. E.; Chiu, Y. W.; Clarke, T.; Eccles, N.; Gill, L. A.; Haye, J. J.; Haywood, H. T.; Hoenig, C. R.; Kausas, M.; Le. J.; Russell, H. L.; Smedley, C.; Tipping, W.; J.; Tongue, T.; Wood, C. C.; Yeung, J.; Rowedder, J. E.; Fray, M. J.; McInally, T.; Macdonald, S. J. Structure activity relationships of $\alpha_{\mathrm{v}}$ integrin antagonists for pulmonary fibrosis by variation in aryl substituents. ACS Med. Chem. Lett. 2014, 5, 1207-1212.

52 Wandzik, K.; Zahn, C.; Dassler, K.; Fuchs, H. Substantial changes of cellular iron homeostasis during megakaryocytic differentiation of K562 cells. Develop. Growth Differ. 2009, 51, 555-565. 
53 Cox, B. D.; Natarajan, M.; Stettner, M. R.; Gladson, C. L. New concepts regarding focal adhesion kinase promotion of cell migration and proliferation. J. Cell Biochem. 2006, $99,35-52$.

54 Conner, S. R.; Scott, G.; Aplin, A. E. Adhesion-dependent activation of the ERK1/2 cascade is by-passed in melanoma cells. J. Biol. Chem. 2003, 278, 34548-34554.

55 Luo, B. H.; Springer, T. A. Integrin structures and conformational signaling. Curr. Opin. Cell Biol. 2006, 18, 579-586.

56 Margadant, C.; Monsuur, H. N.; Norman, J. C.; Sonnenberg, A. Mechanisms of integrin activation and trafficking. Curr. Opin. Cell. Biol. 2011, 23, 607-614.

57 Johansson, M. W.; Mosher, D. F. Integrin activation states and eosinophil recruitment in asthma. Front Pharmacol. 2013, 4, n³3, 1-9.

58 Luque, A.; Gomez, M.; Puzon, W.; Takada, Y.; Sanchez-Madrid, F.; Cabanas, C. J. Activated conformations of very late activation integrins detected by a group of antibodies (HUTS) specific for a novel regulatory region (355-425) of the common beta 1 chain. J. Biol. Chem. 1996, 271, 11067-11075.

59 Manzoni, L.; Belvisi, L.; Arosio, D.; Civera, M.; Pilkington-Miksa, M.; Potenza, D.; Caprini, A.; Araldi, E. M. V.; Monferini, E.; Mancino, M.; Podestà, F.; Scolastico, C. Cyclic RGD-including functionalized azabicycloalkane amino acids as potent integrin antagonists for tumor targeting. ChemMedChem 2009, 4, 615-632. 
60 Marchini, M.; Mingozzi, M.; Colombo, R.; Guzzetti, I.; Belvisi, L.; Vasile, F.; Potenza, D.; Piarulli, U.; Arosio, D.; Gennari, C. Cyclic RGD-peptidomimetics containing bifunctional diketopiperazine scaffolds as new potent integrin ligands. Chem. Eur. J. 2012, 18, 6195-6207.

61 Glide, version 4.5, 2007, Schrödinger, LLC, New York, NY (USA).

62 Xiong, J. P.; Stehle, T.; Zhang, R.; Joachimiak, A.; French, M.; Goodman, S. L.; Arnaout, M. A. Crystal structure of the extracellular segment of integrin alphaVbeta3 in complex with an Arg-Gly-Asp ligand. Science 2002, 296, 151-155.

63 Van Agthoven, J. F., Xiong, J. P., Alonso, J. L., Rui, X., Adair, B. D., Goodman, S. L., Arnaout, M. A. Structural basis for pure antagonism of integrin $\alpha_{v} \beta_{3}$ by a high-affinity form of fibronectin. Nat. Struct. Mol. Biol. 2014, 21, 383-388.

64 Lee, J.; Jin, M-K.; Kang, S-U.; Kim, S. Y.; Lee, J.; Shin, M.; Hwang, J.; Cho, S.; Choi, Y-S.; Choi, H-K.; Kim, S-E.; Suh, Y-G.; Lee, Y-S.; Kim, Y-H.; Ha, H-J.; Toth, A.; Pearce, L. V.; Tran, R.; Szabo, T.; Welter, J. D.; Lundberg, D. J.; Wang, Y.; Lazar, J.; Pavlyukovets, V. A.; Morgan, M. A.; Blumberg, P. M. Analysis of structure-activity relationships for the 'B-region' of N-(4-t-butylbenzyl)-N'-[4-(methyl sulfonylamino) benzyl]-thiourea analogues as TRPV1 antagonists. Bioorg. Med. Chem. Lett., 2005, 15, 4143-4150.

65 Boudignon-Proudhon, C.; Patel, P. M.; Parise, L. V. Phorbol ester enhances integrin alpha IIb beta 3-dependent adhesion of human erythroleukemic cells to activationdependent monoclonal antibodies. Blood 1996, 87, 968-976. 

Downs, V. L.; Penning, T. D.; Russell, M. A.; Wendt, J. A.; Chen, B. B.; Stenmark, H. G.; Wu, H.; Spangler, D. P.; Clare, M.; Desai, B. N.; Khanna, I. K.; Nguyen, M. N.; Duffin, T.; Engleman, V. W.; Finn, M. B.; Freeman, S. K.; Hanneke, M. L.; Keene, J. L.; Klover, J. A.; Nickols, G. A.; Nickols, M. A.; Steininger, C. N.; Westlin, M.; Westlin, W.; Yu, Y. X.; Wang, Y.; Dalton, C. R.; Norring, S. A. Convergent, parallel synthesis of a series of beta-substituted 1,2,4-oxadiazole butanoic acids as potent and selective alpha $\mathrm{v}_{\mathrm{v}}$ eta 3 receptor antagonists. Bioorg. Med. Chem. Lett. 2006, 16, 839-844.

67 Taherian, A.; Li, X.; Liu, Y.; Haas, T. A. Differences in integrin expression and signaling within human breast cancer cells. BMC Cancer 2011, 11, 293 (1-15).

68 Solorzano, C.; Bouquelet, S.; Pereyra, M. A.; Blanco-Favela, F.; Slomianny, M. C.; Chavez, R.; Lascurain, R.; Zenteno, E.; Agundis, C. Isolation and characterization of the potential receptor for wheat germ agglutinin from human neutrophils. Glycoconj. J. 2006, 23, 591-598.

69 Njus, B. H.; Chigaev, A.; Waller, A.; Wlodek, D.; Ostopovici-Halip, L.; Ursu, O.; Wang, W.; Oprea, T. I.; Bologa, C. G.; Sklar, L. A. Conformational mAb as a tool for integrin ligand discovery. Assay Drug Dev Technol. 2009, 7, 507-515.

70 McKinney, S. A.; Murphy, C. S.; Hazelwood, K. L.; Davidson, M. W.; Looger, L. L. A bright and photostable photoconvertible fluorescent protein. Nat. Methods. 2009, 6, $131-133$. 
71 Bedini, A.; Baiula, M.; Spampinato, S. Transcriptional activation of human mu-opioid receptor gene by insulin-like growth factor-I in neuronal cells is modulated by the transcription factor REST. J. Neurochem. 2008, 105, 2166-78.

72 Epik, version 2.2, 2011, Schrödinger, LLC, New York, NY (USA). 
Table of Contents Graphics

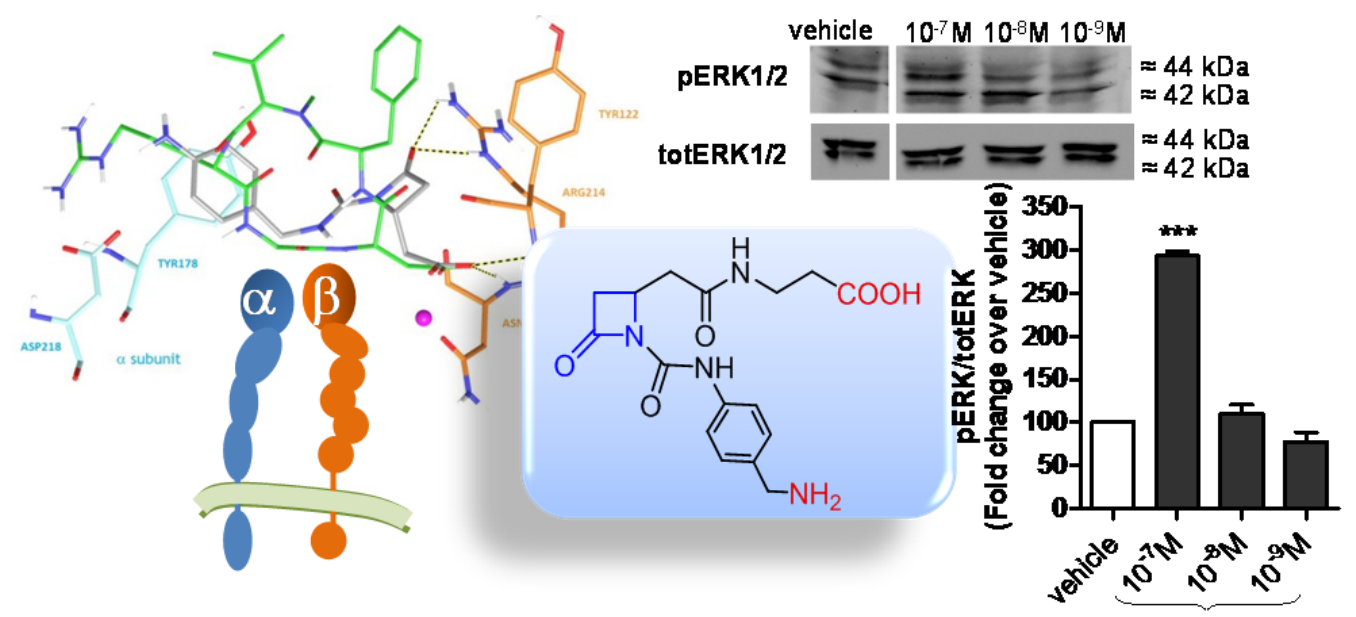

